\title{
Nomenclature of supra-generic units within the Family Scincidae (Squamata)
}

\author{
GLENN M. SHEA \\ Sydney School of Veterinary Science B01, University of Sydney, NSW 2006, Australia \\ Australian Museum Research Institute, Australian Museum, 1 William St, Sydney, NSW 2010, Australia \\ I"'glenn.shea@sydney.edu.au; @ i https://orcid.org/0000-0002-0052-4205
}

\begin{abstract}
The modern classification of skinks is based on a nomenclature that dates to the $1970 \mathrm{~s}$. However, there are a number of earlier names in the family group that have been overlooked by recent workers. These names are identified and their validity with respect to the International Code of Zoological Nomenclature investigated, along with their type genera. In most cases, use of these names to supplant junior synonyms in modern day use is avoidable by use of the Reversal of Precedence articles of the Code, but the names remain available in case of future divisions at the tribe and subtribe level. Other names are unavailable due to homonymy, either of their type genera or the stems from similar but non-homonymous type genera. However, the name Egerniini is replaced by Tiliquini, due to a limited timespan of use of Egerniini. A new classification of the Family Scincidae is proposed, providing a more extensive use of Code-regulated levels of classification, including tribes and subtribes, and a detailed synonymy provided for each taxonomic unit.
\end{abstract}

Key words: Scincidae, Scincinae, Acontiinae, Lygosominae, Lygosomini, Ateuchosaurini, Eugongylini, Mabuyini, Ristellini, Sphenomorphini, Tiliquini

\section{Introduction}

The family Scincidae is the largest family of lizards, with around 1700 species currently recognized, spread over more than 150 genera (Uetz et al. 2019). For a family of this size, it is not surprising that attempts have been made to provide a classification below the family level and above the generic level. The modern classification of skinks began with Mittleman (1952) who, as part of his dismantling of the enormous genus Lygosoma Hardwicke \& Gray 1827 into multiple genera based on the distribution of selected character states, proposed a subfamilial classification. Mittleman listed four subfamilies of skinks, Lygosominae, Mabuyinae, Scincinae and Chalcidinae, with their diagnoses based on a dichotomous key, and only the content of the Lygosominae defined, this being the major topic of his study. No authorship was provided for any of the four subfamilies (although he did provide authorships for genera and species within the Lygosominae), suggesting that Mittleman considered himself as the author of the new names Lygosominae, Mabuyinae and Chalcidinae. Mittleman's subfamilial classification received little attention or acceptance.

Eighteen years later, Greer (1970a) proposed a more explicitly argued subfamilial classification. Although Mittleman had not listed the content of his subfamily Mabuyinae, Greer considered that subfamily to have consisted of what was then five genera: Corucia Gray 1856, Egernia Gray 1838c, Mabuya Fitzinger 1826, Macroscincus Barboza du Bocage 1873a, and Tiliqua Gray 1825 (the five genera that fit Mittleman's diagnosis and that were not listed as part of the Lygosominae by Mittleman). Greer recognized four subfamilies, treating Mittleman's Mabuyinae to be part of the Lygosominae, and his Chalcidinae to be part of the Scincinae. Greer's other two subfamilies, Acontinae and Feylininae, were small groups of burrowing skinks that had earlier been treated by some as not skinks. For example, Boulenger (1887) placed Feylinia Gray 1845 (a member of Greer's Feylininae) and Typhlosaurus Wiegmann 1834a (a member of Greer's Acontinae) in the family Anelytropidae. As Boulenger's classification was widely accepted, and Mittleman did not define the content of his subfamilies other than the Lygosominae, it is not possible to determine whether Mittleman's classification included these genera among the Scincidae, or whether he followed some previous authors in excluding them from the Scincidae. 
Greer's subfamilial classification was not based on reciprocal monophyly. He considered the subfamilies Acontinae, Feylininae and Lygosominae to be independently derived from scincine ancestors, making the Scincinae a basal, paraphyletic group.

Again, Greer did not provide authorships for his subfamilial names, and while some are similar to previously created names, others, like Feylininae and Acontinae, are seemingly based on different stems and hence should be considered independently created names.

Several years later, Greer (1979) proposed an informal division of the Australian members of the Lygosominae, partitioning the genera among three "groups", the Egernia group, the Eugongylus group and the Sphenomorphus group. These reflected his earlier treatment (Greer 1974) of the window-eyed skinks previously treated as a single genus Leiolopisma Duméril \& Bibron 1839 as representing three groups, I, II and III, of which group I belonged to the Sphenomorphus group, and II and III represented basal and derived members of the Eugongylus group. This informal division was widely accepted, although it left unassigned several lygosomine genera, some very large (what were then Apterygodon Edeling 1864, Dasia Gray 1839, Eumecia Barboza du Bocage 1870, Lamprolepis Fitzinger 1843, Lygosoma, Mabuya and Macroscincus) that were not represented in the Australian fauna. Greer (1967, 1970b, 1976, 1977) had earlier considered these to represent five independent derivations from within Mabuya.

Although most authors for the next several decades continued to refer to the Egernia group, Eugongylus group and Sphenomorphus group in discussing relationships among lygosomine skinks, Welch (1982) proposed the assignment of formal tribal names for Greer's groups, creating the tribes Egerniini, Eugongylini and Sphenomorphini, and also placing the residual African lygosomine genera into a nominotypic tribe Lygosomini (Eumecia, Lygosoma, Mabuya, and Macroscincus), not mentioning Apgerygodon, Dasia or Lamprolepis. However, Welch went further in dividing Greer's Eugongylus group into three tribes, with the Eugongylini representing the basal genera, and the Lampropholini and Panaspiini representing the "beta-skink" subgroup (Greer 1979) or Group III (Greer 1974) Greer had recognized, partitioning it into African and Australasian tribes without any reason other than geographic distinction. Welch also created the name Paracontiini for a clade identified by Brygoo (1980) for some of the Malagasy scincines. Brygoo had treated these as a single genus Paracontias Mocquard 1894, with three subgenera Paracontias, Malacontias Greer 1970a and Angelias Brygoo 1980, but Welch considered it was more appropriate to treat them as full genera within a named tribe. However, in so doing he did not explicitly allocate any tribe or tribes for the remainder of the scincines, so by inference treating them all as the nominotypic tribe Scincini. Welch's classification did not explicitly define any of his tribes other than to reference previous authors. However, under the Code (Article 13.1.2) his new names can be considered as defined by reference to previous diagnoses: Greer (1974, 1979) for the Egerniini, Eugongylini, Sphenomorphini and Lampropholini; Perret (1975) for the Panaspiini (using Perret's definition of a genus Panaspis Cope 1868 with five subgenera, the equivalent to Welch's Panaspiini with five genera) and Brygoo (1980) for the Paracontiini.

Welch's tribal names received little use for the next three decades, with most authors overlooking the paper, and continuing to use Greer's more informal names for three groups in the Lygosominae. Welch himself only used the names once (Welch 1983), and then only Sphenomorphini and Lygosomini, ignoring them all in a later publication (Welch et al. 1990). Meanwhile, Greer himself became less convinced that his Egernia group was monophyletic, and renamed it the Mabuya group, adding the residual genera he had not previously allocated to his three lygosomine tribes and treating it as an assemblage of genera lacking a diagnosis based on synapomorphies (Greer 1989), and later still (Greer \& Chong 2007) using the informal term eugongylines to cover all members of his Lygosominae that were not part of the Sphenomorphus group, with his Eugongylus group nested within the eugongylines.

During this period, the advent of karyological, immunological and genetic sequence data continued to affirm the validity of Greer's three groups within the Lygosominae, with some recognizing a fourth group for Mabuya sensu lato plus Dasia and Apterygodon, and a fifth group for Lygosoma sensu lato plus Lamprolepis (Honda et al. 1999a,b, 2000). Further genetic studies have resulted in division of Mabuya and Lygosoma into multiple genera, with progressive refinement of these generic concepts.

Hedges \& Conn (2012) began a new cycle of research on the suprageneric classification of skinks, with a revision of the Caribbean Mabuya, dividing them into multiple genera. Desiring to provide more room for a suprageneric classification, they raised most of the previous groups within Scincidae to families: Mabuyiidae, Egerniiidae, Eugongylidae, Lygosomidae, Sphenomorphidae for the previous informal tribal "groups" within the Lygosominae of Greer (1970a, 1974, 1979) and Honda et al. (1999a,b, 2000), and Acontidae and Scincidae for the previous subfamilies Acontinae and Scincinae, and placing all seven families into an Infraorder Scincomorpha (the equivalent 
of the previous concept of the Family Scincidae). They further partitioned their Mabuyiidae into four subfamilies: Mabuyiinae for the Neotropical genera, Chioniniinae for the Cape Verde genus Chioninia Gray 1845 (into which Macroscincus had previously been subsumed); Dasiinae for the Asian taxa that had previously been separated into a genus Eutropis Fitzinger 1843, plus Dasia, which had long been recognized as related to Eutropis, and Trachylepidinae for the African taxa that had previously been separated into a genus Trachylepis Fitzinger 1843). Like Welch (1982), they did not provide diagnoses for these taxa other than by bibliographic reference to previous papers; however, unlike previous authors, they did provide authorships for the names that had previously been proposed.

Their proposal for these changes to the higher classification of skinks received criticism (Pyron et al. 2013), but was expanded by Hedges (2014) in response, adding two new families (Ristellidae for two small south Indian/Sri Lankan genera; Ateuchosauridae for a single genus of two species) for genera for which affinities were poorly understood, and recognizing a superfamily Lygosomoidea for what had been considered by Greer $(1970 \mathrm{a}, 1974,1979)$ a subfamily Lygosominae. Hence, by the time of the 2014 paper, there were seven families corresponding to what had been considered tribes within a subfamily Lygosominae, together with two additional families (Acontidae and Scincidae) for what had long been considered subfamilies. In the only one of the families that Hedges \& Conn (2012) recognized subfamilies, the Mabuyidae, two of the four subfamilies, Dasiinae and Trachylepidinae, were unable to be demonstrated to be monophyletic based on the analyses of Pyron et al. (2013), and Hedges (2014) suggested that the "content of the subfamilies Dasiinae and Trachylepidinae should be considered unresolved until a more robust phylogeny is obtained". However, subsequent studies (Zheng \& Wiens 2016; Karin et al. 2016) confirmed that not only were some genera not assignable to the subfamilies Hedges \& Conn (2012) had assigned them to, but that the Dasiinae and Trachylepidinae were clearly not monophyletic, with the Mabuyinae of Hedges \& Conn being nested as a lineage within the Trachylepididae, Dasia (type genus of the Dasiinae) being the sister to the combination of Trachylepidinae and Mabuyinae rather than sister to Eutropis, and a slightly revised Eutropis (with the removal of E. novemcarinata to a monotypic new genus Toenayar Karin et al. 2016), being the outgroup to all other members of their Mabuyidae. Hence, there seems to be no reason to recognise sublineages within the broader Mabuyidae, as only the neotropical genera form a significant suprageneric cluster, with other lineages being defined as genera. Thus, providing sublineages within the Mabuyidae (subfamilies or below) would only be providing another set of higher-level names for the existing genera.

Curiously, Hedges \& Conn (2012) and Hedges (2014) did not consider using the Code-regulated categories below subfamily: tribe and subtribe. Use of these categories would have allowed the long-established subfamilies of a family Scincidae to be maintained, while still giving formal taxonomic recognition to the additional suprageneric lineages they recognized, avoiding confusion between differing concepts of the extent of the family Scincidae and the varying concepts of Lygosominae/Lygosomidae/Lygosomoidea. The primary argument used by Hedges (2014) to raise the previous tribes to familial level was to create taxonomic space and reduce the size of the generic groups, yet their classification compressed the higher-level taxonomy of squamates (order and above), while leaving unused an entire suite of lower-level taxonomic categories. While it could be argued that this freed up space for further named units at low taxonomic levels, recent phylogenetic studies have generally failed to provide convincing support for the relationships of many of the genera within the families proposed by Hedges (2014), with only very low support for many branches (Pyron et al. 2013; Zheng \& Wiens 2016), and even varying positions of genera between families. Hence, it is not clear that there is a need for an extensive low-level classification among genera under the families recognized by Hedges (2014), with any proposal for such a classification likely to be unstable.

As a consequence, many recent authors have simply treated the families proposed by Hedges (2014) as subfamilies or tribes under a traditional more-inclusive family Scincidae. This does not alter the recognition of the same nested series of monophyletic lineages, but maintains continuity of application of names.

However, the provision of an increasing number of formal taxonomic names in the family group and its subsidiary classificatory levels has been done without consideration for priority of potential earlier names. The formal proposals for subfamilies and tribes by Mittleman (1952), Greer (1970a) and Welch (1982) lacked any synonymies or authorships for those names, suggesting that all three authors may have considered their names as new. Hedges (2014) did provide authorships and dates for the familial names he used in his classification, noting that Lygosomidae (Lygosominae of Mittleman (1952) and Greer (1970a)) antedated both of those studies, and could be traced to Gray (1845). Hedges (2014) did not consider the potential for any prior names for his other recognized families.

There are several earlier names in the family group proposed within what Mittleman (1952) and Greer (1970a) considered the family Scincidae, and Hedges (2014) considered the infraorder Scincomorpha. Some of these were 
listed in the synonymy of the family Scincidae by Boulenger (1887), but not all, and some are senior synonyms of existing names being used within the Scincidae.

I review the availability and application of these names below, beginning chronologically, then taxonomically.

\section{History of family-group names for skinks prior to Mittleman (1952)}

The first mention of a family group name for a skink species was Scincoides by Oppel (1811). This was explicitly stated to be a "Familia", and contained four genera: Scincus Linné, Seps Raii, Sheltopusik Lacépède and Anguis Linné.

Of these, the Seps of Ray (1693) is pre-Linnean and unavailable, but appears to be based on a southern European skink, probably Chalcides chalcides (Linnaeus 1758), as Ray had collected specimens from sandy coasts at Livorno in 1664 (Raven 1950), within the distribution of that species. Seps has a long history, with the name traceable to Ancient Greek and Latin literature, applied variously to lizards, snakes, centipedes and caterpillars (Bodson 2009). Oppel included in Seps at least three entities: “a) Digiti quatuor. b) Digiti tres. c) Digiti duo etc." This implies he was basing his concept of Seps on that of Daudin (1802), who similarly divided his own genus Seps into species on number of digits: Seps Quadrupède Pentadactyle, Seps Quadrupède Tridactyle, Seps Quadrupede Monodactyle, Seps Bipède Didactyle ou Tridactyle, Seps Bipède Subdidactyle and Seps Bipède Monodactyle.

Anguis Linnaeus 1758 included in its original form a number of unrelated species, many of which are snakes. Oppel's restricted use of the name only specifically mentions two species, Anguis fragilis Linnaeus 1758 (Anguidae) and Anguis meleagris Linnaeus 1758, the latter now Acontias meleagris.

Lacépède (1804) did not create a genus Sheltopusik. Oppel's use of that name (with the combination Sheltopusik novaehollandiae appearing at the end of the account) appears to be his own application of a common name for the anguid Pseudopus apodus (Pallas 1775) to the new species that Lacépède (1804) had described as Bipes lepidopo$d u s$, a pygopod gekkotan, due to Lacépède's vernacular use of "sheltopusick" [sic] in comparing the new Australian species to Pseudopus.

Linnaeus similarly did not create a genus Scincus, although he did (Linnaeus 1758) describe the species Lacerta stincus. This has long been presumed to be an error for scincus (see, for example, Kauffeld 1937; Arnold \& Leviton 1977; Leviton et al. 1992; Anderson 1999; Adler 2012) although if it was an error, Linnaeus did not correct it when preparing the following edition (Linnaeus 1766), where it remains as stincus, and he also used it in both the original and the subsequent reprint of the Museum Adopho-Fridericianum ("Balk" [Linnaeus] 1746, 1749), and in Hasselquist's (1757) account of his travels in the Holy Lands (Linneaus provided the species names in that book (Adler 2012), although Hasselquist himself (1751) used Lacerta scincus). Linnaeus seems to have deliberately been following Seba (1735) who provided both the names Stincus and Scincus (p. 112: "Est \& alia earum species, in officinis Pharmaceuticis usitata, quam Stinci, vel Scinci marini nominee distinguunt"; "Stincus"; "Scincum"), and selected Stincus from the two options. Scincus is a Latin noun of long use, and it was this that was subsequently used for generic names, independent of Linneaus' Lacerta stincus. However, Stincus also has a long history of use, particularly in the earlier pharmaceutical literature. The earliest instances I can find of its use are by Vincent of Beauvais in his Speculum Naturale, likely written between 1244 and 1260 (I cite the printed version of 1494), Simon of Genoa, in his Clavis Sanationis, likely written about 1290 (first printed version 1473; I cite the 1514 version), John Mesue's In Antidotarium, likely written in the late $13^{\text {th }}$ century (I cite the 1550 edition), and in an early Latin translation (likely by John of Copua and written about 1300) of Moses Maimonides' On Coitus, originally written in Arabic (Bos et al. 2019). It also appears in the version of the Gart der Gesuntheit of Prüss (1507) (along with Scincus), Mangetus' (1687) Pharmacopoea Schodero-Hoffmanniana, Potter's (1702) Archaeologia Graeca, and Sidren's (1750) dissertation on the Materia Medica in Linnaeus' Regno Animali. Another use of Stincus was reported by Sidren (1750) and Gronovius (1756) as from "Rondel. Pisc. 2 p. 231." However, Rondelet (1555; the second volume of his Libri de Piscibus Marinis) uses Scincus. The subsequent use of the specific epithet scincus rather than the original stincus, while an unjustified emendation, is in universal use in the modern literature (subsequent to the revival of scincus over officinalis Laurenti 1768 as a specific epithet by Flower 1933 and Loveridge 1936), and hence to be maintained under Article 33.2.3.1. A Google Scholar search locates 952 uses of the name Scincus scincus, but none for Scincus stincus as a valid name (the few citations of Scincus stincus are to note that the name has been replaced by Scincus scincus).

A post-Linnaean generic name Scincus appears to have first been created by Gronovius (1763), who included 
four species: Scincus pedibus pentadactylis, unguiculatis, digitis teretibus; Scincus pedibus pentadactylis inermibus: digitis lobatis; Scincus pedibus brevissimis, pentadactylis, unguiculatis; cauda truncoque longissimis, cylindraceis, and Scincus pedibus posticis brevissimis subulatis, monodactylis; anticis nullis; caudae apice nudo. Gronovius himself based the name on his earlier pre-Linnaean work (Gronovius 1756), where only two species were described. Gronovius (1763) was suppressed for the purposes of nomenclature by Opinion 89 (Anonymous 1925), due to the non-binomial nature of the work.

The next appearance of a generic name Scincus was by Garsault (1764), based on an illustration, and that illustration was subsequently identified as Scincus scincus var. laterimaculatus Werner 1914 by Dubois \& Bour (2010), and thus laterimaculatus Werner is the type species by monotypy of Garsault's Scincus, by subsequent designation (Article 67.2.2). Most authors have overlooked this earlier creation of a genus Scincus in favour of a later Scincus by Laurenti (1768) (e.g., Stejneger 1936). Laurenti (1768) listed two species in the genus: Scincus officinalis and $S$. stellio. Laurenti referred to illustrations with descriptions by Seba (1735), a pre-Linnaean source, and hence, both by providing diagnoses and bibliographic reference to a description with an illustration, Laurenti is the author of both species names.

Scincus officinalis Laurenti is considered a synonym of Lacerta stincus Linnaeus (Flower 1933; Loveridge 1936), and it has been subsequently assumed (Stejneger 1936) that because of this synonymy, the type of Scincus is Linnaeus' Lacerta scincus/stincus due to tautonymy. However, this is not the case, as there is no mention of Linnaeus' term scincus or stincus in Laurenti's genus Scincus (Article 68.4), precluding direct tautonymy. As there are two species in Laurenti's Scincus, a type species by subsequent designation is required, and this was provided by Fitzinger (1843) (Laurenti's second species, stellio, is based in part on Seba's Plate 10, Nos 4 \& 5, which relate to lizards with imbricate scales from America and Ambon, and must be a composite of two unrelated species). Some authors (Leviton et al. 1992; Anderson 1999) state that officinalis was proposed by Laurenti to avoid tautonomy with the generic name Scincus, and that it is a replacement name for Lacerta stincus, but this is incorrect. Laurenti lists a species scincus within his genus Seps, but does not attribute that name to Linnaeus, nor did he have any issue with such tautonymy, recognizing a species Scincus stellio along with a genus Stellio. Instead, his creation of the specific epithet officinalis within Scincus is likely based on Seba (1735), cited by Laurenti, and in reference to Seba's statement "Est \& alia earum species, in officinis Pharmaceuticis usitata...", referring to the use of skinks for pharmaceutical functions (hence based on the Latin officium = function, referring to its use as described in ancient pharmacopeias).

In the absence of a genus Scincus created by Linneaus, it is not clear which concept of the genus Oppel was following, as he merely stated "Genus hoc omnes fere in systema suum receperunt herpetology" [Almost all men have accepted this genus into their system of herpetology]. Hence, he appears to be treating all subsequent uses of the genus Scincus as equal, and based on this statement, I treat Scincus Garsault (1764), currently the earliest postLinnaean author to have created such a genus in a work that is still available under the Code, as the type genus, even if Oppel may not have seen that work.

Oppel recognized three subdivisions within Scincus, the first represented by Sc. Galliwasp, the second by Sc. Mabouya and the third by Sc. Schneideri. Although none of these names were attributed to an author, all correspond to names used within Scincus by Daudin (1802), although Daudin spelt Scincus galliwasp as $S$. gallivasp and Scincus schneideri as S. schneiderii. Curiously, Oppel does not mention either stincus Linnaeus or officinalis Laurenti among the species in the genus, although he must be considered to have included stincus Linnaeus as part of the genus through his attribution of the name Scincus to Linnaeus. Of the three species that Oppel explicitly lists in Scincus, type genus of his family Scincoides, Scincus Galliwasp is now considered a synonym of Celestus occiduus (Shaw 1802), a diploglossid, Scincus Mabouya is now Mabuya mabouya, and S. schneiderii is now Eumeces schneiderii.

Under Article 11.7 of the Code, Oppel's Scincoides is an available name in the family-group, being based on Scincus, formed from the stem of an available generic name indicated by express reference to the generic name. While the suffix -oides is not a currently recognized suffix at any level in the family-group (Article 29.2), it is clear that Oppel used it as a formal name, not a vernacular name. Under Article 32.5.3, the incorrectly formed suffix does not prevent recognition of the name as presented by Oppel, but the suffix must be corrected. Gray (1838c) first presented it in the correct form, Scincidae.

Rafinesque (1815) also created a family-group name based on Scincus, listing a subfamily Scincidia (and subfamilies Sepsidia and Bipedinia) under a family Meguria. No definition was provided for the family name Meguria, 
but he did list (under the subfamily Sepsidia) a genus Megurus, without diagnosis or included species. While the lack of included species does not in itself preclude that generic name from being available (Article 67.2.2), the additional lack of any diagnosis for that genus to distinguish it from the other genera in the subfamily Sepsidia or the family Meguria does appear to invalidate the name Megurus (Article 12.1), and hence the family name Meguridae (Article 11.7.1.1). However, Scincidia is given the briefest of diagnoses (Queue conique, doigts onguiculés [tail conical, digits clawed]) and Rafinesque lists five genera within it: Scincus Daudin, Eltroplepurus Rafinesque, Lupeurus Rafinesque, Mabuya Rafinesque, and Meiodactis Rafinesque. The latter four names have no definitions or associated species, and remain nomina nuda, although Mabuya Rafinesque is presumably the same entity as the later Mabuya Fitzinger. Scincus Daudin 1802, as an available generic name, must be considered the type genus of Rafinesque's Scincidia and, along with the brief diagnosis, validates that name.

The second family created by Oppel (1811) for a skink genus was Chalcidici, which he stated to be based on Chalcides Lacepede [Lacépède], but also included the genera Bipes (attributed to Latreille, and now Bipes Latreille 1801, Amphisbaenidae), Ophisaurus (attributed to Daudin, and now Ophisaurus Daudin 1802, Anguidae) and Bimanus (attributed to Lacepede, and now treated as Bimanus Oppel 1811, a synonym of Bipes Latreille). "Lacepede" is presumably with reference to the Histoire Naturelle des Quadrupèdes Ovipares et des Serpens (Lacépède 1788). As was the case with Oppel's attribution of the type genus of his Scincoides, his attribution of a generic name Chalcides to Lacépède is incorrect, as Lacépède only uses chalcides as a species name. Oppel's full statement is "Lacepede [sic] huic generi primus nomen dedit, quod deinde Brongniart, Latreille, Daudin et Duméril characteribus propriis optime distinxerunt" (Lacépède first gave the name for this genus, which Brongniart, Latreille, Daudin et Duméril then optimally distinguished with particular features). These references seem to be to Brongniart (1800), Sonnini \& Latreille (1801), Daudin (1802) and Duméril (1805), all of whom defined a genus Chalcides. Brongniart (1800) must be considered the first of these to have defined the genus in the sense used by Oppel (1811). However, Brongniart's use of the generic name does not specifically identify a type species, but lists "Ex. d'esp." [Examples of species]: "Ch. pentadactyla; (Lac. chalcides. L.). Seps, serpens, anguina, bipes, apus, etc." While no authors are cited for these names, they can be readily linked to species of Lacerta (at the time the default genus for all lizards) and Anguis described by Linnaeus (1758, 1766) (L. chalcides, L. seps, L. anguina, A. bipes), Bloch (1776) (L. serpens) and Gmelin (1789) (L.apus). Brongniart likely obtained all six names from Gmelin (1789), where they are listed as species of Lacerta, with all but seps listed in sequence as the last five species of Lacerta. Brongniart does not cite Laurenti (1768), who first created a genus Chalcides. However, as with Laurenti's Chalcides, that of Brongniart includes Lacerta chalcides (though providing it with a replacement name, Chalcides pentadactyla) and so the concept is the same for both, with Lacerta chalcides being the type species by tautonymy (Article 68.4).

One could try to argue that Chalcides Brongniart 1800 is a junior homonym of Chalcides Laurenti 1768, and hence unavailable for selection as a type genus (Article 39), but this would be splitting hairs. Chalcidici Oppel, like Scincoides Oppel, has an unconventional form for the suffix for a family group, but this in itself does not invalidate the name.

Complicating the application of Chalcidici (or Chalcididae as emended) are later homonyms for very different concepts. Among squamates, Daudin (1802), to whom Oppel (1811) also attributed the generic name, created a second Chalcides. He specifically excluded Lacerta chalcides from his genus (placing it in his genus Seps) and stated that his Chalcides was not that of Laurenti. Chalcides Daudin instead included four species: Chalcides tetradactylus Daudin 1802 (now Tetradactylus tetradactylus, a gerrhosaurid), Chalcides tridactylus Daudin 1802, now Bachia flavescens (Bonnaterre 1789), a gymnophthalmid, Chalcides monodactylus Daudin 1802 (now also Bachia flavescens), and Chalcides propus Daudin 1802 (based on Chamaesaura propus Schneider 1801, now a synonym of Bipes canaliculatus, an amphisbaenian). The creation of Chalcides Daudin led to a long period when the generic name Chalcides was applied to gymnophthalmids rather than scincids, only reverting back to application to the current skink genus in the latter part of the $19^{\text {th }}$ century (e.g., Boulenger 1887). During the period when Chalcides was applied to gymnophthalmids, Gray (1825) created another family name Chalcididae, with three genera, Chalcides Daudin, Chirotes Cuvier 1816, and Cophias Gray 1825, while Fitzinger (1826) created a similar family Chalcidoidea, based on Chalcides Cuvier 1816 [= Chalcides Daudin], Brachypus Merrem 1820, Cophias Merrem 1820 (the latter two based on divisions of Chalcides Cuvier) and Heterodactylus Spix1825. Chalcididae Gray and Chalcidoidea Fitzinger must be considered unavailable as family-group names, as Chalcides Daudin is a junior homonym, but not a synonym, of Chalcides Laurenti, and hence not available for use as a type genus (Article 39). In Scincidae, Chalcidici Oppel is either both a senior synonym and homonym of Chalcidinae Mittleman 1952 (if it is considered 
that Mittleman's name is independent), or the first creation of a name subsequently resurrected (without attribution) by Mittleman.

Chalcidici Oppel and Scincoides Oppel are both based on genera now recognised as skinks, and were published in the same work. I can find no subsequent author who cited both names and determined relative priority. Boulenger (1887), who provided synonymies for family group names and finalized the use of Chalcides for the skink genus to which it is now applied, overlooked Oppel's work, attributing Scincidae to Gray (1825), and used Gray's (1825) concept of Chalcididae, referring the latter name, along with the gymnophthalmids, to the family Teiidae. Hence, using the principle of First Reviser (Article 24.2) I give Scincoides Oppel priority over Chalcidici Oppel for the lineage to which skinks belong.

Gray (1825), who next presented a familial classification of lizards that recognised skinks or subunits of skinks as distinct entities with formal names, recognized a family Sincidae, containing the genera Sincus [sic], Cicigna Gray 1825, Gymnophtalmus [sic] Merrem 1820, Tiliqua and Trachydosaurus Gray 1825, but made no mention of the earlier Scincoides Oppel or Scincidia Rafinesque. Gray attributed the name Sincus to Daudin (1802) and included the species Lacerta sincus Linnaeus 1758 . Hence, he appears to have simply mis-spelt the original Scincus of Daudin (1802) and Lacerta stincus of Linnaeus, and his Sincidae must be corrected to Scincidae (Article 35.4.1). This concept of the Scincidae, like that of Oppel, includes some taxa no longer considered to be skinks (Gymnophthalmus (type genus of the family Gymnophthalmidae) and Cicigna, based on Scincus sepiformis Schneider 1801, now a synonym of Tetradactylus seps (Linnaeus 1758), a gerrhosaurid).

Gray (1825) also recognized one other genus that is now considered a skink: Acontias Cuvier 1816, which he placed in his family Angudidae (now Anguidae). Being based on the genus Anguis, the latter name is not an available family group name for any scincid sublineage.

Fourteen years later, Gray (1838a-c, 1839), proposed a classification of the "slender-tongued saurians" including his next opinion of skink taxonomy. Most skink genera (Chiamela Gray 1839, Dasia, Egernia, Hagria Gray 1839, Herinia Gray 1839, Lygosoma, Riopa Gray 1839, Ristella Gray 1839, Scincus, Seps, Siaphos [a mis-spelling of Saiphos Gray 1831], Sphaenops Wagler 1830, Tachydosaurus [a mis-spelling of Trachydosaurus], Tetradactylus Cuvier 1829, Tiliqua and Tridactylus Cuvier 1829) were placed in a family Scincidae, along with Anguis, Aprasia Gray 1839 (Pygopodidae), Celestus Gray 1838c (now in Diploglossidae), Dorfia Gray 1839 (possibly an anguidsee Gray 1845), Ophiodes Wagler 1830 (Diploglossidae), Siguana Gray 1839 (possibly an anguid—see Wermuth 1969), and Stenostoma Wagler 1824 (Leptotyphlopidae).

However, the newly described skink genus Rhodona Gray 1839 (now a synonym of Lerista Bell 1833) was considered to form a distinct family Rhodonidae, in which he also tentatively placed Soridia Gray 1839 (also now a synonym of Lerista), and Lerista itself, although he had not at that time been able to examine specimens of the latter genus.

A third family, Acontiadae, was created for Acontias, together with the Sri Lankan burrowing scincines that Gray placed in Nessia Gray 1839 and Evesia Gray 1839 (the latter now a synonym of Nessia), along with Bipes (the content of which in Gray's concept consisted of two species now in the scincine genus Scelotes Fitzinger 1826, and is hence different to Bipes Latreille 1801, an amphisbaenid), while the scincid genera Ablepharus Fitzinger 1824 and Cryptoblepharus Wiegmann 1834b were both placed in the family Gymnophthalmidae. Both Rhodonidae and Acontiadae (later corrected to Acontiidae, using the correct Latinised stem, by Cope 1864) are validly published names in the family group, and have type genera based on type species that are in the Scincidae.

Rhodonidae was also used by Gray (1841a,b), this time consisting of Rhodona, Soridia and Chelomeles Duméril \& Bibron 1839 (the latter now a synonym of Hemiergis Wagler 1830). Gray placed other genera now in Hemiergis (Chiamela [part], Tetradactylus and Tridactylus) in the Scincidae.

In his final major foray into lizard classification, Gray (1845) continued to recognize an ever-expanding family Scincidae, now including 46 genera (Anguis, Ateuchosaurus Gray 1845, Brachymeles Duméril \& Bibron 1839, Camilia Gray 1845, Carlia Gray 1845, Celestus Gray 1845, Chelomeles, Chiamela, Cyclodus Wagler 1830, Dasia, Diploglossus Wiegmann 1834a, Egernia, Elania Gray 1845, Eumeces Wiegmann 1834a, Euprepis Wagler 1830, Hagria Gray 1845, Hemiergus (mis-spelling of Hemiergis), Heteropus Fitzinger 1826, Hinulia Gray 1845, Keneuxia Gray 1845, Lardella Gray 1845, Leiolopisma, Lipinia Gray 1845, Lygosoma, Mabouya Duméril \& Bibron 1839, Microlepis Gray 1839, Mocoa Gray 1845, Norbea Gray 1845, Omolepida Gray 1845, Ophiodes, Otosaurus Gray 1845, Plestiodon Duméril \& Bibron 1839, Podophis Wiegmann 1834a, Rhodona, Riopa, Scincus, Senira Gray 1845, Siaphos, Silubosaurus Gray 1845, Soridia, Tetradactylus, Tiliqua, Trachydosaurus, Tribolonotus Duméril \& Bibron 
1839, Tropidolepisma Gray 1845, Tropidophorus Duméril \& Bibron 1839, and tentatively Ristella), and some 124 species. This concept resulted in the subsuming under Scincidae of the type genus of his previous Rhodonidae, and the transfer to the Scincidae (by creation of the genus Tribolonotus) of Zonurus novaeguineae Schlegel 1834, which he had previously (Gray 1838b) left in Zonurus Merrem, 1820 in the family Zonuridae (now Cordylidae). Of the genera listed by Gray in his Scincidae, six (Anguis, Camilia, Celestus, Diploglossus, Microlepis and Ophiodes) are now not considered skinks, and Lardella is a nomen nudum, rejected later in the same work, p. 271)

With such a diversity of skinks, Gray provided a complex ramifying key as an organizing framework. The first version of this key, presented on pp. 70-73, divided the family into five initial groups, with further divisions of each of these groups. I provide a compilation of the first two divisions:

I. Scales thin, smooth, not striated not keeled. Nostrils in a single smooth plate, without any lunate groove behind. Tail round, tapering, unarmed.

A. Toes depressed, fringed on the sides. Head wedge-shaped. Rostral depressed, keeled in front. Nostril in the middle of the upper edge of the nasal, with a triangular supranasal above the rostral.

B. Toes compressed, simple. Head subquadrangular. Rostral erect, triangular. Nostril in the middle of a shield.

II. Scales thick, bony, rugose, striated, or 1 or more keeled. Rostral rounded in front. Body fusiform. Limbs 4 , strong. Toes 5-5, compressed.

C. Tail compressed, keeled above. Scales of the tail keeled, spinose, of the body smooth. Head-shields rugose, closely applied to the skull. Temples shielded. Lower eyelid scaly. Preanal plates few, large.

D. Tail rounded, tapering, rarely spinose, not keeled above, thick, bony, rugose, or 3 or 5 keeled, rarely smoothish.

E. Tail round, tapering, unarmed, not keeled above. Scales minutely striated, and sometimes 1-keeled. Supranasals two pair.

To the first of these groups (I. A.), Gray (1845: 70) appended the name Scincina, but no names were applied to the other four groups in this version.

Following this initial synopsis, Gray provided a similar categorization of the genera into groups scattered among his descriptions of the genera and species on pp. 74-120, though with slightly different statements of character states and combinations. This time, he provided names to the five major groups. I provide the full second classification, with a list of the genera included in each category, and the group names boldened:

I. Scales thin, smooth, not striated nor keeled, unarmed. Nasal flat, smooth, without any lunate groove behind. Tail round, tapering, unarmed.

A. Toes depressed, fringed on the sides. Head wedge-shaped. Rostral depressed, keeled in front. Nostril in the middle of the upper edge of the nasal, with a triangular supranasal above the nostril. Scincina.

[genus Scincus]

B. Toes compressed, simple. Head subquadrangular. Rostral erect, triangular. Nostril in the middle of nasal shield. Lygosomina.

a. Supranasal plate none. Body fusiform. Lower eyelid covered with scales. Frontoparietal separate. [genera Elania, Hinulia, Keneuxia]

b. Supranasal plate none. Body fusiform. Lower eyelid with a transparent disk.

* Frontoparietal plate single, lozenge-shaped [genus Mocoa, part]

** Interparietal plates 2, separate [genera Mocoa, part; Leiolopisma, Lipinia]

*** Supernasal plates none. Body and tail elongate, subcylindrical. Limbs 4, weak, far apart.

Rostral erect, triangular.

$\dagger$ Toes elongate, rather compressed, unequal.

[genera Chelomeles, Hemiergis, Lygosoma, Ristella, Tetradactylus]

$\dagger \dagger$ Toes short, thick, cylindrical

[genera Omolepida, Podophis]

d. Supranasal plates none. Body and tail cylindrical, elongate. Limbs rudimentary or wanting. Rostral rather produced and depressed in front. Frontonasal rudimentary, the internasal and frontal being separated 
by a broad straight suture. Head half conical.

[genera Rhodona, Siaphos, Soridia]

e. Supranasal plates 2, Body fusiform. Tail tapering.

[genera Eumeces, Mabouya, Otosaurus, Plestiodon]

f. Supranasal 2. Body and tail subcylindrical, elongate. Limbs 4, short, weak, or rudimentary.

[genera Brachymeles, Chiamela, Hagria, Riopa, Senira]

g. Supranasals 4 or 6 . Body and tail subcylindrical, elongate. Limbs 2 or none. Scales placed in transverse lines on the back, and in oblique ones on the sides.

[genera Anguis, Ophiodes]

II. Scales thick, bony, rugose, 1 or more keeled, or closely longitudinally striated. Rostral rounded in front. Body fusiform. Limbs 4, generally strong. Toes 5-5 (rarely 4-5), compressed.

C. Tail compressed, keeled above. Scales of the tail keeled, spinose. Head-shields rugose, closely applied to the skull. Temple shielded. Lower eyelid scaly. Preanal plates few, large. Tympanum superficial. Tropidophorina. [genera Norbea, Tribolonotus, Tropidophorus]

D. Tail rounded, tapering, rarely spinose, not keeled above. Scales thick, bony, rugose, or 3- or 5-keeled, rarely smoothish. Drum of ear deep. Tiliquina.

* Supranasal shields none.

$\dagger$ Lower eyelid scaly. Toes 5-5. Nostril with a curved groove behind it.

[genera Cyclodus, Egernia, Silubosaurus, Trachydosaurus, Tropidolepisma]

$\dagger \dagger$ Lower eyelid scaly. Toes 5-5, compressed. Nasal shield flat, without any groove behind the nostril.

[genus Ateuchosaurus]

$\dagger \dagger$ Lower eyelid transparent. Toes 4-5. Body and tail cylindrical, elongate.

[genus Heteropus]

** Supranasal shields 2, distinct. Scales 3- or 5-keeled. Palate toothed. Nasal oblong, with the

nostril in its hinder end, and a small nasoloreal behind it.

[genera Dasia, Euprepis, Tiliqua]

E. Tail round, tapering, unarmed, not keeled above. Scales minutely striated, and sometimes 1-keeled. Supranasals two pair. Diploglossina.

[genera Camilia, Celestus, Diploglossus, Microlepis].

In addition to the genera within the Scincidae, Gray continued to treat the skinks Ablepharus and Cryptoblepharus as part of the family Gymnophthalmidae, adding to that family four more skink genera (Lerista, Menetia Gray 1845, Miculia Gray 1845 and Morethia Gray 1845), and maintained recognition of a family Acontiadae, now restricted to just Acontias, Nessia and Evesia. Additionally, he created three more families for genera now considered skinks: Ophiomoridae (for Ophiomorus Duméril \& Bibron 1839), Sepsidae (for the genera Amphiglossus Duméril \& Bibron 1839, Gongylus Wagler 1830, Heteromeles Duméril \& Bibron 1839, Scelotes, Seps, Sphaenops and Thyrus Gray 1845), and Typhlinidae (for the genera Feylinia, Typhline Wiegmann 1834a and Dibamus Duméril \& Bibron 1839; the latter now in Dibamidae).

The subunits within the Scincidae (Scincina, Lygosomina, Tropidophorina, Tiliquina and Diploglossina) are new formal names within the family group, and are acceptably formed under the Code, from type genera Scincus, Lygosoma, Tropidophorus, Tiliqua and Diploglossus, using the -ina termination for subtribes in modern form, although clearly Gray was treating these groups as the next category below family, i.e., subfamily. Only one of these is problematic. Tiliquina included the ten genera Ateuchosaurus, Cyclodus, Dasia, Egernia, Euprepis, Heteropus, Silubosaurus, Tiliqua, Trachydosaurus, and Tropidolepisma, with Tiliqua implicitly the type genus for the Tiliquina.

However, Gray's concept of Tiliqua changed over time. The generic name was first created by Gray (1825), at which time it consisted of just two nominal species: Tiliqua tuberculata Gray and Lacerta sincoides White [sic]. No definitions were provided for either species by Gray, leaving Tiliqua tuberculata Gray as a nomen nudum at the time. However, an extended description of Tiliqua tuberculata was provided by Gray (1827), based on what is evidently, from the combination of morphology and locality (Seal Island in King George the Third's Sound), Egernia kingii (Gray 1838c). Gray included in the synonymy of his description of Tiliqua tuberculata both Lacerta 
scincoides and Scincus tuberculatus Merrem, 1820, the latter name also based on Lacerta scincoides. Hence, Gray's (1827) description of Tiliqua tuberculata, though nominally a synonym of Tiliqua scincoides, was based on a misidentification of this species. Lacerta scincoides was subsequently designated the type species of Tiliqua by Cogger et al. (1983) avoiding any potential confusion.

Two years later (Hardwicke \& Gray 1827), Gray had begun to expand his original concept of Tiliqua, adding two species from India to the genus, Tiliqua carinata (Schneider 1801) and a new species, Tiliqua trivittata, both now placed in the genus Eutropis.

A few years later, Gray (1831) had expanded Tiliqua to 26 species: T. aenea Gray 1831, now Copeoglossum nigropunctatum; T. bellii Gray 1831, now Leiolopisma telfairii (Desjardin 1831); T. bicolor (Harlan 1825), now Plestiodon laticeps; T. bistriatus (Spix 1825), now Varzea bistriata; T. bistriatus Gray 1831, now Trachylepis gravenhorstii (Duméril \& Bibron 1839), T. capensis Gray 1831, now Trachylepis capensis; T. carinatus (Schneider 1801), now Eutropis carinata; T. crotaphomelas (Lacépède 1804), now a synonym of T. scincoides; T. cyprius (Cuvier 1829) [as cyprinus], now Eumeces schneiderii; T. erythocephala (Gilliams 1818), now Plestiodon laticeps Schneider 1801; T. fasciatus Gray 1831, now Diploglossus fasciatus; T. homolocephalus (Wiegmann 1828), now Trachylepis homalocephala; T. lateralis (Say 1822), now Scincella lateralis; T. mabouya (Shaw 1802), now Mabuya mabouya (Bonnaterre 1789); T. microlepis Gray 1831, now Diploglossus microlepis; T. multiseriatus (Cuvier 1829) [as multiscutatus], now Eumeces schneiderii (Daudin 1802); T. nigroluteus (Quoy \& Gaimard 1824); T. nigropunctatus (Spix 1825), now Copeoglossum nigropunctatum; T. occidua (Shaw 1802), now Celestus occiduus; T. ocellatus (Schneider 1801), now Chalcides ocellatus (Forskål 1775); T. quinquelineatus (Linnaeus 1766), a likely synonym of Plestiodon fasciatus (Linnaeus 1758); T. sloanii (Daudin 1802), now Spondylurus sloanii; T. taeniolata (White 1790), now Ctenotus taeniolatus; T. tenuis Gray 1831, now Concinnia tenuis; T. trivittatus Hardwicke \& Gray 1827, now Eutropis trivittata, and T. whitii, now T. scincoides). This concept included species now spread amongst 15 genera and two families (Scincidae and Diploglossidae).

Eight years later, Gray (1838c) had expanded the genus to 50 species. Of the 26 species in 1831, 17 (T. aenea, T. bellii, T. bistrigata Gray (emendation of his earlier bistriatus), T. capensis, T. carinata, T. cyprinus, T. erythrocephala, T. fasciata, T. multiseriatus, T. nigrolutea, T. occidua, T. ocellatus, T. sloanii, T. taeniolata, T. tenuis, T. trivittatus and T. whitii) remained, and were joined by 33 additional species: T. affinis Gray 1838c, now Trachylepis affinis; T. albolabris Gray 1838c [current identity uncertain—Hedges \& Conn 2012]; T. ascensionis Gray, 1838c [current identity uncertain-Mausfeld et al. 2002]; T. australis Gray 1838c, now Ctenotus australis; T. bibronii Gray 1838c, now Eutropis bibronii; T. buchanani Gray 1838c, now Cryptoblepharus buchanani; T. chinensis Gray 1838c, now Plestiodon chinensis; T. cyanurus (Lesson 1830), now Emoia cyanura; T. duperreyi Gray 1838c, now Acritoscincus duperreyi; T. elegans Gray 1838c, now Concinnia tenuis; T. entrecasteaux Gray 1838c (nomen nudum), now Pseudemoia entrecasteauxii (Duméril \& Bibron 1839); T. fernandi Burton 1836, now Mochlus fernandi; T. interruptopunctata Gray 1838c [current identity unknown]; T. jamaicensis Gray 1838c, now Diploglossus monotropis (Kuhl 1820); T. kingii, now Egernia kingii; T. labillardii Gray 1838c (nomen nudum), now Ctenotus labillardieri (Duméril \& Bibron 1839); T. leucopsis Gray 1838c, now Liopholis whitii (Lacépède 1804); T. maculata Gray 1838c, now Trachylepis maculata; T. microcephala Gray 1838c, now Chalcides ocellatus; T. napoleonis Gray 1838c, now Egernia napoleonis; T. punctata Gray 1838c, now Trachylepis atlantica (K. Schmidt 1945); T. punctata Gray 1838c [not the same species as described under this name on p. 289, the previous page; current identity uncertain]; T. quinquestriata Gray 1838c, now Trachylepis quinquetaeniata (Lichtenstein 1823); T. reevesii Gray 1838c, now Scincella reevesii; T. richardi Gray 1838c, now Spondylurus sloanii; T. similis Gray 1838c (nomen nudum), T. striata Gray 1838c, now Celestus hewardii Gray 1845; T. stoddartii Gray 1838c [current identity uncertain —Cogger et al. 1983]; T. subrufa Gray 1838c [current identity uncertain, possibly Trachylepis homalocephalus — see Fitzsimons, 1943]; T. trilineata Gray 1838c, now Acritoscincus trilineatus; T. vachellii Gray 1838c [current identity uncertain - Cogger et al. 1983], and T. vanicoriensis Lesson [never published by Lesson, and a nomen nudum as listed by Gray].

Gray's 1845 version of Tiliqua was reduced to just four species: Tiliqua fernandi, now Mochlus fernandi; Tiliqua grisea Gray 1845, now Dasia grisea; Tiliqua multicarinata Gray 1845, now Eutropis multicarinatus (Gray tentatively attributes the species to Kuhl 1820, although no such species name is provided there, only Scincus multifasciatus, now Eutropis multifasciatus), and Tiliqua rufescens (Shaw 1802), now Eugongylus rufescens (although Gray's concept of that species included both Eugongylus rufescens and several Eutropis and Trachylepis species), while the type species of Tiliqua was considered to be part of Cyclodus, along with C. nigroluteus.

While it could be argued that Gray's (1845) concept of Tiliqua was a misidentification of that genus, and there- 
fore that Gray's Tiliquina applied to what is now a mixture of Eugongylus, Dasia, Eutropis and Mochlus species, under Article 65.1, the type genus of a family name is assumed to be correctly identified. As the type species of Tiliqua was also considered part of the Tiliquina (but assigned to Cyclodus at the time), Tiliquina should be treated as having the correct application of the genus Tiliqua as its type genus.

Of the other three scincid families created by Gray (1845), Ophiomoridae is an available name in the family group, accompanied by a diagnosis on its original creation. Sepsidae is not available, due to the type genus being a junior homonym (Article 39). Gray attributed the generic name Seps to Daudin (1802), which is a junior homonym of Seps Laurenti 1768. Daudin explicitly stated that his Seps was different to that of Laurenti, with Laurenti's genus not including Lacerta seps Linnaeus 1758, while Daudin's genus was framed around that species, which becomes the type species of Seps Daudin by tautonomy. The type species of Laurenti's Seps was subsequently designated by Stejneger (1936) as Seps caerulescens Laurenti 1768, a synonym of Lacerta agilis Linnaeus 1758, making Laurenti's genus a synonym of Lacerta. Further, Lacerta seps Linnaeus 1758 is not a skink but a gerrhosaurid (now Tetradactylus seps), even though Gray (1845) did not explicitly include this species among the members of his genus Seps and all species included by Gray in the genera in his Sepsidae are skinks.

Typhlinidae is a more complex situation, and one that has not been subsequently considered. Wiegmann (1834a), in a footnote corrigendum on the last page of his monograph, apparently overlooked by Gray (1845), considered his Typhline preoccupied by Typhline Wagler 1830, and so provided a replacement name Typhlosaurus for Typhline Wiegmann, and Typhlosaurus has been universally used since. While this would appear to make Gray's Typhlinidae unavailable due to the type genus being a junior homonym, Wagler (1830) actually spelt his generic name Typhlina, not Typhline (though he did state that it was derived from the Greek Typhline). This one-letter difference in the spelling of the two generic names is sufficient to avoid homonymy (Article 56.2). Typhlina Wagler was the subject of a case before the ICZN due to priority over Leptotyphlops Fitzinger 1843 (Stimson et al. 1977) and has been suppressed (Melville 1982) for the purposes of the Law of Priority, but not for the Law of Homonymy. While this means Typhlina remains an available name as a homonym, this does not affect the false claim of homonymy with Typhline Wiegmann. However, in that Typhlosaurus has been universally used for over a century (notwithstanding recent changes to the generic boundary between Typhlosaurus and Acontias by Lamb et al. 2010), while Typhline has not, Typhlosaurus should not be replaced by Typhline at the generic level (Article 23.9). In order to invoke Article 23.9, Typhlosaurus has been used in the following 25 papers by more than 10 authors in the preceding 50 years: Rieppel (1981, 1982); Haacke (1986); Jacobsen (1987); Bates (1988); Broadley (1990); Bates et al. (1998); Bauer et al. (1999); Bauer \& Branch (2001); Daniels et al. (2002, 2006); A. Schmidt (2002); Michels \& Bauer (2004); Brandley et al. (2005); B. Branch \& Kyle (2005); Goldberg (2006); Heidemann et al. (2008); V. Schneider \& Bauer (2009); Lamb et al. (2010); Moch \& Senter (2011); Bauer (2014a-d), and Zhao et al. (2020). This reversal of priority only affects the relative priority of Typhline and Typhlosaurus when both names are regarded as belonging to the same taxon. It does not prevent Typhline being used for a family-group name.

Gray's subunits within his Scincidae other than Lygosomina have been largely unused. Charles Walter De Vis, working at the Queensland Museum, seems to be the only person to use the names in the form that Gray provided. De Vis (1886), in describing as new Calyptotis flavienter, now Calyptotis scutirostrum (Peters 1874), used Lygosomina. De Vis (1888), in a paper describing new skink species, used the name Tiliquina under the family Scincidae, preceding a description of a new species of Tiliqua, T. longicauda [now a synonym of Cyclodomorphus gerrardii (Gray 1845)], and Lygosomina prior to the description of seven new skinks: Anomalopus lentiginosus, now a synonym of Anomalopus leuckartii (Weinland 1862); Heteropus vertebralis, now a synonym of Liburnascincus mundivensis (Broom 1898); Hinulia ambigua, now Eremiascincus sp.; Hinulia domina [current identity uncertain-Cogger et al. 1983]; Hinulia tigrina, now Concinnia tigrina; Mocoa delicata, now Lampropholis delicata; Mocoa spectabilis, now Saproscincus spectabilis, and Ophioscincus frontalis, now Coeranoscincus frontalis. De Vis (1890), dealing with a collection of reptiles from New Guinea, used Tiliquina for Tiliqua gigas (Schneider 1801) and Lygosomini for Heteropus bicarinatus Macleay 1877, now Carlia bicarinata, Heteropus fuscus Duméril \& Bibron 1839 (now in Carlia, though the species reported under that name by De Vis is now Carlia luctuosa (Peters \& Doria 1878)) and Hinulia jobiensis Meyer 1874 , now Sphenomorphus jobiensis, as well as three new species: Emoa cuneiceps, now a synonym of Emoia longicauda (Macleay 1877); Emoa pallidiceps, now Emoia pallidiceps (De Vis 1890), and Homolepida englishi, now a synonym of Sphenomorphus muelleri (Schlegel 1837). However, De Vis (1888) also provided the name Egernina prior to describing three new species in that genus, E. bungana, now E. major (Gray, 1845), E. lauta, now a synonym of Lissolepis luctuosa (Peters 1866), and E. rugosa. This seems to have created a 
new name in the family group. While there is no separate diagnosis for De Vis' Egernina, it is validated by being used in combination with the genus Egernia (Article 12.2.4).

While John Edward Gray was gradually partitioning the ever-increasing number of skink species, herpetologists in continental Europe were working independently.

Cuvier $(1816,1829)$ recognised six families of lizards, of which "Les Scincoidiens" was one. As a vernacular name, this family name is not available nomenclaturally. Cuvier's concept of a skink was, as with other workers of his era, composite, including various species now placed in the families Amphisbaenidae, Cordylidae, Diploglossidae, Gymnophthalmidae and Pygopodidae.

Merrem (1820) recognised 11 genera in a lineage for which he used the name Chalcidici. Although he did not attribute the name to any author and did not specifically refer to it as a family, it would appear likely that Merrem's Chalcidici was that of Oppel (1811), and that he considered Oppel's Scincoides a synonym. While most of the genera in Merrem's Chalcidici were not skinks, the lineage included as its largest genus Scincus. Other genera representing skinks in the lineage were Bipes Merrem 1820 (not Bipes Latreille 1801), Pygodactylus Merrem 1820, and Seps (though seemingly not the Seps of Daudin 1802), all monotypic. Merrem's Seps consisted only of Seps chalcidica $[=$ Lacerta chalcides Linnaeus], under which species name Merrem included Chalcides tetradactyla Laurenti 1768, Chamaesaura chalcis Schneider 1801, Chalcides seps Latreille 1801 and Seps tridactylus Daudin 1802, although Daudin (1802) had included Lacerta chalcides Linnaeus under his Seps pentadactylus, and placed Chamaesaura chalcis and Chalcides seps under his Seps tridactylus.

Fitzinger (1826), in his first attempt at a classification of the Reptilia, placed nine genera (Heteropus Fitzinger 1826 (a nomen nudum as first coined), Mabuya, Pygodactylus, Scelotes, Scincus, Seps, Spondylurus Fitzinger 1826, Tiliqua and Zygnis Oken 1816) in a family Scincoidea, most of them skinks, and also recognised a family Chalcidoidea for the South American gymnophthalmids, a similar arrangement to Gray (1825).

Wagler (1830) included 10 genera of skinks (Ablepharus, Cyclodus, Euprepis, Gongylus, Lygosoma, Scincus, Seps, Sphaenops, Trachysaurus and Zygnis Oken 1816) amongst a variety of other genera now placed in other families in a family Autarchoglossae, a much more inclusive family concept than that of previous authors. Again, this name is unavailable in the family-group, as it was not based on a type genus forming the stem of the family name, although it has been widely used (as Autarchoglossa) at the suborder level or as a clade name outside Linnaean classification.

Wiegmann (1834a), in a preliminary classification of reptiles prefacing his Herpetologia Mexicana, recognised a family Scinci, containing the skink genera Acontias, Cyclodus, Euprepes, Lygosoma, Peromeles, Podophis, Pygodactylus, Scelotes, Scincus, Seps, Sphenops, Spondylurus, Trachysaurus and Zygnis, along with Anguis (Anguidae) and Otophis (Anguidae). Other skink genera (Ablepharus, Lerista, Typhline) were placed in the Gymnophthalmi (now Gymnophthalmidae), along with Gymnophthalmus and Pygopus (Pygopodidae).

In Paris, Duméril \& Bibron (1839) covered the skinks in Volume 5 of their Erpetologie Generale. They based their skink classification on an unpublished manuscript, Tabulae Synopticae Scincoideorum compiled by JeanThéodore Cocteau, who had died in the previous year. Cocteau's classification, as outlined by Duméril \& Bibron (1839: 520-525) used vernacular names for the classification of skinks above genera. Duméril \& Bibron (1839) similarly used vernacular names for higher classification, placing the majority of their skink genera into a single family Scincoïdiens or Lépidosaures, the former originally coined by Cuvier (1829), and the latter newly formed. Lépidosaures itself was a replacement for the name Lépidosomes, which they proposed in the preliminary classification for lizards that they presented in the second volume of their encyclopedic work (Duméril \& Bibron 1835: 595), but which they considered subject to confusion with the generic name Lepidosoma Spix, 1825. Within the family Scincoidiens, they proposed three named subunits, based on the form of the eyelids: Saurophthalmes, Opiophthalmes and Typhlophthalmes. Most skink genera, with scaly eyelids, were in the Saurophthalmes. Those genera with the lower eyelid replaced by a spectacle were placed in the Ophiophthalmes, and the two genera (Dibamus and Typhline) with the eye covered by a scale, were placed in the Typhlophthalmes. Being vernacular names, and with no type genera bearing a stem for those names, the subfamily names proposed by Duméril and Bibron must be considered unavailable for nomenclatural purposes in modern nomenclature (Article 11.7.1).

However, the next author to deal with skink classification, Leopold Fitzinger in Vienna, did create names that are available, being Code-compliant. Fitzinger (1843), in his second attempt at a classification of the Reptilia, worked with a system that attempted to classify genera into higher categories based on a numerical pattern, following the Naturphilosophie school, using in his case the numbers 3 and 5. The result was a proliferation of names in the 
family group and at higher levels. At the higher levels, Fitzinger adopted the names of Duméril and Bibron (1839), formalizing these names in Latin rather than vernacular form, giving a Sectio Lepidosomata (using the earlier name coined by Duméril \& Bibron (1835), and with content largely equivalent to the modern family Scincidae, with a few genera now placed in other families), with three tribes, Saurophthalmi, Ophiophthalmi and Typhlophthalmi, with these three names being attributed to Cocteau. Two of these group names (Saurophthalmi, Typhlophthalmi) lack a type genus providing the stem for the names, so that they remain unavailable names (Article 11.7.1). However, within the other tribe, Fitzinger created a genus Ophiophthalmus for Lialis burtonis Gray 1835, a pygopod, thus creating a valid type genus for his Ophiophthalmi, and for the first time creating an available name (while Article 11.7.2 of the Code allows for authorship of a vernacular name subsequently validated by conversion to a non-vernacular name to remain with the original author, Ophiophthalmes Duméril \& Bibron was not created with an available type genus, and so it remains invalid, leaving Fitzinger as the author of Ophiophthalmi in the family-group). For the purposes of this paper further consideration of this is not relevant, although is it is a junior synonym of Pygopodidae Gray 1841 b, a gekkotan family.

Within these three tribes, Fitzinger's philosophical framework required where possible five groups, and thus he created five families in both the Saurophthalmi and Ophiophthalmi. The former tribe contained the families Eutropides (with genera Eutropis, Heteropus, Trachylepis and Tropidophorus), Euprepae (with genera Eulamprus Fitzinger 1843, Euprepis, Gongylomorphus, Leiolopisma, and Liosoma Fitzinger 1843), Eumecae (with genera Amphiglosus, Anguis, Brachymeles, Chelomeles, Cyclodus, Gongylus, Heteromeles, Leptosoma, Lygosoma, Ophiomorus, Podophis, Pygodactylus, Seps, Sphenosoma and Trachysaurus), Scinci (with genera Brachystopus, Preapeditus, Scincus, Sphenops and Zygnis) and Acontiae (with genera Acontias and Ramphosaurus Fitzinger 1843, now a junior synonym of Nessia). Ophiophthalmi included the five families Cryptoblephari (for the genus Cryptoblepharis, a misspelling of Cryptoblepharus), Gymnophthalmi (for Gymnophthalmus), Ablephari (for Ablepharus), Ophiopses (for Ophiopsis Fitzinger 1843, a junior synonym of Lerista) and Pygopoda (for Pygopus and Ophiophthalmus Fitzinger 1843, now a junior synonym of Lialis). For Typhlophthalmi, with many fewer species and genera to work with, Fitzinger was only able to create a single family, Typhlomorphi, for the genera Dibamus and Typhlomorphus Fitzinger 1843 (now Typhlosaurus).

Again, while the terminations of the names are not those used in modern nomenclature, this does not prevent their validity (Article 11.7.1.1), as they are proposed along with clearly stated type genera (Articles 12.2.4), either available names previously published, or newly proposed. The latter generic names, while not provided with diagnoses, are themselves available under the Code (Article 12.2.5) due to being accompanied by explicitly stated type species, all species names previously available.

Of the new family names, Ablephari, Cryptoblephari, Eumecae, Euprepae, Eutropides, Ophiopses and Typhlomorphi relate to type genera that are now skinks. Six of the seven antedate names that are currently in use for subfamilies and tribes of skinks. Ablephari and Ophiopses are based on type genera that are now considered part of the Sphenomorphini/Sphenomorphinae/Sphenomorphidae of various authors (first dating back to Welch 1982), although Ophiopses is not available due to Ophiopsis Fitzinger 1843 being a junior homonym of Ophiopsis Agassiz 1834; Cryptoblephari is based on a type genus now considered part of the Eugongylini/Eugongylinae/Eugongylidae (first dating back to Welch 1982) and Euprepae and Eutropides are based on type genera that are now considered part of the Mabuyinae/Mabuyidae (dating back to Mittleman 1952) - this issue of senior synonyms will be considered below. The sixth name, Eumecae, is more problematic.

Fitzinger's concept of the genus Eumeces, a name correctly attributed to Wiegmann (1834a), lists as the type species of that genus Eumeces rufescens Wiegmann. However, while Wiegmann included the species Scincus rufescens Merrem 1820, along with Scincus pavimentatus Geoffroy Saint Hilaire 1827 and Scincus punctatus Schneider 1801, as the three original species in Eumeces (originally proposed as a subgenus of Euprepes), Fitzinger's listing of rufescens as the type species is invalid. Wiegmann (1835) himself rapidly altered the content of Eumeces, stating that he was in error in including Scincus punctatus and S. rufescens in that subgenus, while Duméril \& Bibron (1839) had designated S. punctatus as the type species, four years before Fitzinger. Stejneger (1926) and Taylor (1935) both argued that Wiegmann's (1835) removal of both punctatus and rufescens from the subgenus excluded them from being chosen as type species, and used this argument to apply the name to the genus to which it has been applied since. However, Article 69.4 precludes typification by elimination, seemingly leaving the type species designation by Duméril \& Bibron (1839) as the first Code-compliant designation. As Scincus punctatus Schneider is Lacerta punctata Linnaeus, 1758, the name Eumeces would therefore seem to be based on that species. Bauer (2013) con- 
sidered the identity of Lacerta punctata, noting that the description was composite and had been applied both as the type species of Euprepis (where it was considered a synonym of Scincus homolocephalus Wiegmann 1828) and to the Indian Riopa punctata, and stabilized that nomenclatural issue by lectotype designation, fixing Lacerta punctata to the Riopa species, and noting the existence of the earlier designation by Loveridge (1957) of Scincus agilis Raddi 1823 as the type species of Euprepis Wagler 1830, thus making that genus a synonym of Mabuya. However, if Lacerta punctata were also the type species of Eumeces through the action of Duméril \& Bibron (1839), the name Eumeces would need to transfer to the Lygosomini sensu stricto, as a senior synonym of Riopa Gray 1839. Luckily, both Stejneger (1926) and Taylor (1935) overlooked another commentary, by Weigmann (1836), that specifically states that Scincus pavimentatus is the type species of Eumeces ("die typische Art") avoiding the nomenclatural issue and maintaining the current application of that genus name.

Hence, Fitzinger had been the third person to nominate a genotype and chose the third of the original species listed as his genotype. Fitzinger's invalid selection of Scincus rufescens as the type species of the genus has no effect on the subsequent application of the generic name, but it does create a problem with use of Fitzinger's concept of the type genus of his family Eumecae. Scincus rufescens Merrem is currently considered part of the genus Eugongy$l u s$, type genus of the Eugongylini, within the subfamily Lygosominae, but Eumeces, in its current application, is a scincine. Family-group names are considered to have had their type-genera correctly applied (Article 65.2), but this may not be the case in this instance. Fitzinger's (1843) classification is unfortunately incomplete, with the published component for skinks consisting only of the Schema Systematis, listing family group names as defined only by their type genera, and the type genera only by their type species - the full text only includes the first "Sectio", Amblyglossae, while skinks were placed in the second "Sectio", Leptoglossae. Fitzinger did not list pavimentatus among the type species of the 61 genera and subgenera in his Lepidosomata, so it is not clear to which family or genus he considered that species to be assigned. The only definition that can be interpreted is that Fitzinger considered his genotype for Eumecae as being framed around a species that is not a member of the genus Eumeces. Hence, under Article 65.2.1, Fitzinger's Eumecae is unable to be applied in the family-group without a ruling by the International Commission on Zoological Nomenclature, although its potential priority over Eugongylidae Welch, 1982 can also be avoided by reversal of precedence (see below), leaving it incertae sedis but not problematic for the stability of nomenclature. As will be seen below, the existence of Eumecae Fitzinger in turn will resolve another problematic family-group name with deliberately misidentified type species of the genotype.

In addition to the issues with Fitzinger's Ablephari, Cryptoblephari, Eumecae, Euprepae and Ophiopses antedating Eugongylini, Mabuyini and Sphenomorphini, all of these names antedate Lygosomina of Gray (1845), now used for the umbrella category of which Eugongylini, Mabuyini and Sphenomorphini are part. Typhlomorphi is a junior objective synonym of Acontinae/Acontidae (dating back to Gray 1839) and hence of less significance.

Fitzinger's names subsequently appeared in an encyclopedia by Kollar (1847) to which Fitzinger contributed, and in a summary of his classification in Isis von Oken in the same year (Fitzinger 1847), while Eutropides and Eumecae were also used by Tschudi (1845) when describing new genera and species from Peru. They have not been used in the literature since then.

Following about two decades after Gray and Fitzinger's contributions, Cope (1864) considered skinks when discussing family-level and higher relationships among reptiles. Although he did not mention the previous literature or provide the generic content of the families he recognised, the families appear to largely be based on those of Gray (1845). He recognised a Chalcididae, grouped with Teidae, Lacertidae and Ecpleopidae on the basis of fused premaxillary bones (p. 228), but while diagnosing the latter three families, he states (p. 229) "I do not know the complete characters of the Chalcidae [sic] but they are very near the Lacertidae". Hence, his Chalcididae is presumably that of Gray (1845) and represents the Gymnophthalmidae of modern authors, rather than being based on the scincid genus Chalcides. Cope also recognised and distinguished families Scincidae, Sepsidae and Acontiidae, as well as a subfamily Opheomorinae ([sic] based on a genus Opheomorus, placing it within the Anguidae. I presume that Cope's Opheomorus and Opheomorinae are respectively mis-spellings of Ophiomorus Duméril \& Bibron 1839 and Ophiomoridae Gray 1845. Cope (1864) also created the new family name Anelytropidae, adding to Typhlosaurus, Feylinia and Dibamus(?), the basis of Gray's Typhlinidae (thought to be preoccupied, presumably due to the assumed homonymy of the type genus), the new genus Anelytrops Duméril 1856. Unfortunately, Anelytrops was rapidly synonymized with Feylinia by Barboza du Bocage (1873b) and Cope (1885) attempted to restore this loss by adding to the family a new genus, Anelytropsis for a new species from Mexico, no longer considered confamilial with Feylinia, apparently hoping that Anelytropsis would instead become the type genus to maintain his name 
Anelytropidae. The Code (Article 40.1) allows generic synonyms to remain the type genera for family-group names, and does not allow for replacement of the type genus. However, before adopting this path, Cope (1875) altered the name of his original Anelytropidae to Feyliniidae, although he subsequently reverted to using Anelytropidae, not even mentioning his Feyliniidae in a subsequent synonymy (Cope 1900).

Boulenger (1887), in a major work that would have ongoing influence on lizard systematics for more than half a century, largely accepted the framework of Cope, based on internal anatomical features, but recognised an expanded Scincidae, incorporating Gray's Rhodonidae, Sepsidae, Acontiidae and Ophiomoridae in its synonymy, without recognizing any subfamilies, but still treated Feylinia and Typhlosaurus as part of the Anelytropidae, although he overlooked Gray's Scincina, Lygosomina, Tiliquina, Tropidophorina, and Diploglossina and Cope's Feyliniidae. Boulenger also returned the generic name Chalcides to the Scincidae, finalizing the change from Gray's usage of that name for a genus of gymnophthalmids. Boulenger (1885) summarized the family-level classification he used in a short paper preceding the main Catalogue of the Lizards.

Fürbringer (1900) included Acontias in his concept of Scincidae, thus by inference synonymizing the Acontiidae with Scincidae, but retained Anelytropidae as a distinct family, adding Voeltzkowia to it.

Camp (1923) used a variety of characters, mostly internal, and adding musculature to the osteology utilized by Cope (1864) to re-examine lizard higher systematics. He left the Scincidae as the expansive group of Boulenger (1887) and Fürbringer (1900), but recognised that Feylinia and Anelytropsis were not closely related, splitting a family Feyliniidae from Anelytropsidae, although apparently treating the former name Anelytropidae Cope as unavailable. Camp was not explicit about the placement of Typhlosaurus, the other genus of the Boulenger's and Cope's Anelytropidae, but did list Typhlosaurus as a feyliniid when listing the taxonomic distribution of some character states of the hyoid apparatus (p. 340). He was similarly coy about the placement of Voeltzkowia, mostly referring to it as a member of the Scincomorpha or Scincoidea. However, at one point he does list it as a scincid (p. 386) implying he treated it as a member of the Scincidae. Camp did not give any authorship for his Feyliniidae, and did not mention Cope (1875), so presumably thought he was creating a new replacement name.

\section{Recent divisions within the Scincinae and Acontiinae}

While Scincidae sensu Hedges (2014) (formerly Scincinae of Greer, 1970a) has now subsumed the former Feyliniidae of Cope (1875) and Feylininae of Greer (1970a), following Whiting et al. (2003), and the current concept is monophyletic in some analyses (Pyron et al. 2013) or nearly so (e.g., J. Austin \& Arnold 2006; Brandley et al. 2012; Zheng \& Wiens 2016), contra Greer's (1970a) evolutionary hypothesis, it does show multiple divergent sublineages and further divisions of this lineage may be recommended in the future. The type genus, Scincus, consistently groups with Eumeces and Scincopus Peters 1864 (Brandley et al. 2005, 2008, 2012; Pyron et al. 2013; Zheng \& Wiens 2016). The Madagascan genera (Amphiglossus, Brachyseps Erens et al. 2017, Flexiseps Erens et al. 2017, Grandidierina Mocquard 1894; Madascincus Brygoo 1981, Paracontias, Pseudoacontias Barboza du Bocage 1889; Pygomeles Grandidier 1867 and Voeltzkowia Boettger 1893) consistently cluster together, though with varying arrangements within that cluster (Whiting et al. 2004; Brandley et al. 2005, 2012; Schmitz et al. 2005; Crottini et al. 2009; Pyron et al. 2013; Erens et al. 2017; Zheng \& Wiens 2016). Feylinia, Melanoseps Boulenger 1887 and Typhlacontias Barboza du Bocage 1873b consistently cluster together, as do Scelotes and Proscelotes de Witte \& Laurent 1943 (Whiting et al. 2003, 2004; Brandley et al. 2005, 2008; Pyron et al. 2013; Zheng \& Wiens 2016). However, other genera float, with different placements in different analyses. The large genera Brachymeles and Plestiodon are variously sequentially basal to the rest of the scincines and lygosomines, or in an unresolved polychotomy with the rest of the scincines and lygosomines (Brandley et al. 2005, different analyses; Zheng \& Wiens 2016), in an unresolved basal polychotomy with all other skinks (Brandley et al. 2008), or sister taxa, but with a largely unresolved polychotomy with other scincines (J. Austin \& Arnold 2006; Pyron et al. 2013). Chalcides is generally linked to the three major sub-Saharan African scincine clusters (the three lineages represented by Feylinia and its relatives, Scelotes plus Proscelotes, and the Madagascan genera), but variously as part of an unresolved basal polychotomy with them (Brandley et al. 2005, 2008), sister to the Feylinia and Scelotes lineages (Brandley et al. 2008), sister to the Malagasy genera plus Melanoseps (Brandley et al. 2012), basal to them all (Pyron et al. 2013), or with very weak support for the latter arrangement (Zheng \& Wiens 2016). The two Seychelles genera, Pamelaescincus Greer 1970c and Janetaescincus Greer 1970c, are consistently sister taxa (Brandley et al. 2005; J. 
Austin \& Arnold 2006; Pyron et al. 2013; Zheng \& Wiens 2016), and this genus pair, Gongylomorphus Fitzinger 1843, Sepsina Barboza du Bocage 1866 and the monotypic Hakaria Steindachner 1899 also consistently cluster with the sub-Saharan African scincines, but float within that group (Whiting et al. 2003, 2004; Brandley et al. 2005, 2012; J. Austin \& Arnold 2006; Pyron et al. 2014; Zheng \& Wiens 2016). Ophiomorus, Mesoscincus Griffith, Ngo \& Murphy 2000 and Eurylepis Blyth 1854 float around near the base of the scincines in different analyses, mostly without strong support, although Brandley et al. (2012) recovered strong support for a sister relationship between Eurylepis and the lineage consisting of Scincus, Scincopus and Eumeces, while Pyron et al. (2013) recovered strong support for a sister-pair relationship of Ophiomorus and Mesoscincus. Despite the strong support in this one analysis, Ophiomorus and Mesoscincus are morphologically and geographically very different, and I suspect this result is unlikely to be maintained in future analyses.

Unfortunately, four south Asian scincine genera (Barkudia Annandale 1917, Chalcidoseps Boulenger 1887, Ophioseps Beddome 1870 and Nessia) and the poorly-known east African genus Scolecoseps Loveridge 1920 remain to be included in any phylogenetic analysis. When relationships among the sampled genera become more stable, and the missing genera are added, it may be appropriate to recognize tribes within the Scincinae, and if so, Ophiomoridae, Anelytropidae (with Feyliniidae/Feylinidae as a synonym) and Paracontiini are sequentially available for application to major scincine lineages, but not Chalcidinae, due to homonymy of type genus.

Despite the uncertainty about relationships within the Scincinae, two recent papers have created additional names in the family group for scincines and acontiines, but both are problematic. Griffith et al. (2000) explored the relationships among what was the genus Eumeces sensu lato, using cladistic analyses of morphology, and recovered a polyphyletic Eumeces, dividing that genus into four genera. As one of the genera was recovered as outside the lineage consisting of Lygosominae plus other scincines, including Scincus, they created a subfamily Eumecinae for that genus to maintain monophyly of both Lygosominae and Scincinae. However, they incorrectly assigned the generic name Eumeces to the lineage occurring in North America and East Asia, rather than the genus containing the type species of Eumeces (naming the latter Novoeumeces) - they hoped to be able to transfer the generic name Eumeces to the most species-rich genus rather than the one to which the name belonged under the Code of Zoological Nomenclature, in the expectation that the ICZN would change the type species for Eumeces, an action that has not been supported. Hence, their Eumecinae is deliberately not based on the genus Eumeces, but to the genus now known as Plestiodon. This creates a nomenclatural issue, and if Eumecinae is used in future, application of that name will require a decision by the Commission (Article 65.2.1). However, recent phylogenetic analyses have not recovered Plestiodon as being outside the group consisting of other skinks, but instead have recovered a monophyletic Scincinae (Pyron et al. 2013) or a Scincinae that includes Plestiodon in the same major lineage as Scincus (Zheng \& Wiens 2016), obviating any need for recognition of a subfamily Eumecinae for Plestiodon. Further, Eumecinae Griffith et al. 2000 is a homonym of Eumecae Fitzinger 1843 when terminations are corrected (itself based on a misapplication of the generic name Eumeces), invalidating it.

In one of many poorly-written diatribes he has penned, Hoser $(2015 \mathrm{a}, \mathrm{b})$ proposed a new tribal and subtribal classification of the Scincinae and Acontiinae. Hoser's self-aggrandising works have long been controversial, and many authors have recommended they be ignored due to their poor quality and dubious ethics (e.g., Kaiser et al. 2013, Wüster et al. 2021). However, in that they are in general published in accordance with the Code of Zoological Nomenclature, many of the names he has coined are available names under the Code, whether or not the taxonomy they reflect warrants recognition. Hoser appears to suffer from an extreme case of what has been termed the Mihi itch (Evenhuis 2008) or nomenclatural mihilism (Dubois 2008), seeking recognition by the abundance of his names. Hoser's self-published works largely involve searching the literature for phylogenetic trees and coining names for any previously unnamed branches, using often-plagiarised listings of morphological characters to attempt to justify recognition of the lineages (e.g., Denzer et al. 2016). His classification of the acontiines and scincines is nomenclaturally worse than usual for his labours. Most of the new tribal and subtribal names he has proposed are based on type genera he creates in the same papers, splitting long-recognised genera in line with any previous indication for subgroupings rather than using the long-recognised generic names as type genera, clearly wanting to scratch his itch. However, in attempting to provide morphological justification for the genetic groupings (which he generally fails to acknowledge as the source of his classifications), he has often had to resort to diagnosing his tribal and subtribal lineages by diagnoses of the genera contained within. In many cases, these "diagnoses" do not fulfil the requirements of Article 13.1, in that they diagnose the multiple genera contained by the higher group, but no attempt has been made to diagnose the higher lineage by a diagnosis that "states in words characters that are purported to differentiate the [tribal or subtribal] taxon", nor are such names accompanied by "a bibliographic reference to such 
a published statement". Hoser has also divided the Scincinae into multiple tribes and subtribes without identifying a nominotypic tribe, overlooks the numerous existing names at the family-group level within the Acontiinae and Scincinae, and has often used incorrectly formed tribal and subtribal names, both by using incorrect suffixes, and by incorrectly forming the stem of the name from the type genus.

To begin the consideration of Hoser's proposal, I first present the taxonomy he proposed, as the names are scattered through the text of his work without any overarching summary:

Subfamily Acontinae

Tribe Acontinini

Subtribe Acontinini (for the genus Acontias sensu lato, which Hoser divides into two genera, one with an additional subgenus).

Subtribe Typhlosauriina (for the genus Typhlosaurus sensu lato, which Hoser divides into three subgenera)

Subfamily Scincinae

Tribe Starkeyscinciini

Subtribe Starkeyscinciina (based on the genus Ophiomorus sensu lato, which Hoser divides into five genera)

Subtribe Culexlineatascinciina (based on the genus Mesoscincus sensu lato, which Hoser divides into two genera)

Tribe Parabrachymeliini (based on the genus Brachymeles sensu lato, which Hoser divides into two genera, one with a subgenus)

Tribe Adelynhoserscinciini (based on the genus Plestiodon sensu lato, which Hoser divides into 8 genera, with an additional 12 subgenera, which he partitions among three subtribes)

Subtribe Adelynhoserscinciina (part of Plestiodon sensu lato)

Subtribe Asiascinciina (part of Plestiodon sensu lato)

Subtribe Funkiskinkiina (part of Plestiodon sensu lato)

Tribe Eumeciini (based on the sum of Eumeces, Eurylepis, Scincopus and Scincus)

Tribe Janetaescincus (based on Janetaescincus and Pamelascincus)

Tribe Gongylomorphiini (based on Gongylomorphus plus Chalcides)

Subtribe Gongylomorphiina (based on Gongylomorphus)

Subtribe Chalcidiina (based on Chalcides, within which Hoser recognises four subgenera)

Tribe Sloppyscinciini (based on the sum of most of the remaining African scincines, from among which Hoser names numerous new genera)

Subtribe Sloppyscinciina (based on the Malagasy scincines Amphiglossus sensu lato, Pygomeles and

Voeltzkowia; Hoser creates an additional four genera and six subgenera)

Subtribe Feyliini (based on Feylinia, Malacontias, Sepsina and Typhlacontias)

Subtribe Hakariina (based on Hakaria)

Subtribe Paracontiina (based on the genera Madascincus sensu lato, Pseudoacontias and Paracontias;

Hoser creates two new genera and two new subgenera from Madascincus, but with one of the subgenera also referred to as a full genus in various parts of the paper)

Subtribe Scelotiina (based on the sum of Scelotes and Proscelotes, from among which Hoser recognises one new monotypic genus and a new monotypic subgenus; Hoser also includes in the subtribe a genus Pseudoacontias Bocage 1899, a name and author/year combination which does not exist, but appears to be a duplication of Pseudoacontias Barboza du Bocage 1889, which he also places in his Sloppiscinciina) Subtribe Sirenoscinciina (based on Sirenoscincus Sakata \& Hikida 2003)

Tribe Nessiini (consisting only of Nessia).

Hoser does not mention the scincine genera Barkudia, Chalcidoseps, Scolecoseps or Sepsophis; it is not clear whether he overlooked them, or had no idea where to put them into his classification, as they had not been previously included in any phylogeny.

Of the tribal and subtribal names created by Hoser, many are incorrectly formed. Hoser seems to believe that either the suffix -iini and -iina are correct for these two classification levels, rather than the Code-compliant -ini and -ina, or that the stem of his type genera terminate in -i in each case. I deal with the formation of the names in the next section. 
However, he has also incorrectly used the termination -iini for his subtribe Acontinina (as well as incorrectly forming the stem). He similarly uses the spelling Gongylomorphiini when formally erecting a subtribe for Gongylomorphus (though correctly spelling it as Gongylomorphina in the textual use of the name), and Feyliniini in the formal heading when creating that subtribe for Feylinia (though correctly spelling it as Feyliniina in diagnosing that entity).

He overlooks the existence of Typhlomorphi Fitzinger 1843 and Typhlinidae Gray 1845 as senior synonyms of his Typhlosauriina and Ophiomoridae Gray 1845 as a senior synonym of both his Starkeyscinciini and Starkeyscinciina (bizarrely, Hoser attempts to justify use of his new generic name Starkeyscincus as the type genus because "the term Ophiomorpha is already in widespread use in zoology" (Hoser 2015a: 50) apparently confusing omorus (neighbour) with morphus (form)). His Eumeciini, although incorrectly formed from an erroneous stem, is a junior homonym of both Eumecae Fitzinger 1843 and Eumecinae Griffith et al. 2000, and unwarranted as the earliest available name for that tribe, if recognised, would be Scincini, the nominotypic tribe for the subfamily. His Chalcidiina, again incorrectly formed, is a junior homonym of Chalcidinae Mittleman 1952 and Chalcidici Oppel 1811. His tribe Sloppyscinciini is a junior synonym of Anelytropidae Cope 1864, Feyliniidae Cope 1875, Feyliniinae Camp 1923 and Paracontiini Welch 1982, and his subtribe Paracontiina is a junior homonym of Paracontiini Welch 1982. However, his subtribe Feyliniina is not a junior homonym of Feylininae Camp 1923, due to the different stem employed in creating the name, not based on a Greek or Latin word, but is a junior homonym of Feyliniidae Cope 1875, in turn an unwarranted replacement name for Anelytropidae Cope 1864.

In the cases where Hoser has created new tribal or subtribal names for lineages that were formerly treated as single genera, he has been able to diagnose those entities by repeating existing morphological diagnostic character states, although he generally has not cited his sources for these (see a similar pattern of unattributed plagiarism in his writings on agamids; Denzer et al. 2016). However, for the following names, he has been unable to come up with a single unifying diagnosis, and simply attempts to "diagnose" those entities by a formulaic approach that states that they may be diagnosed by the separate diagnoses for each of the multiple included genera, an approach that does not satisfy Article 13.1: Eumeciini, Feyliniina, Janetaescinciini, Paracontiina, Scelotiina, Sloppyscinciini and Sloppyscinciina. Two other names, Gongylomorphiini and Starkeyscinciini are also only diagnosed by the sum of the separate diagnoses for the included taxa, but in this case, those taxa include subtribes that consist of only previously defined broader genera, and thus under Article 36.1, the names were validly created by the valid creation of their subtribes Gongylomorphiina and Starkeyscinciina. The diagnosis for Gongylomorphiina is an exact duplicate of (with one minor change to avoid reference to a subsequent diagnosis in the original source), but does not reference, Greer's (1970c) diagnosis for the sole included genus Gongylomorphus. Starkeyscinciina is validated by a diagnosis that exactly duplicates the generic diagnosis for the genus Ophioscincus (which Hoser has divided to create a different type genus for the subtribe) provided by Boulenger (1887), again a source not referenced by Hoser for this diagnosis.

\section{Formation and spelling of the names in the family group}

A few of the names proposed within the family group by previous authors have been incorrectly formed, either originally or subsequently.

The most obvious of these is Lygosomina Gray 1845, now variously Lygosomini (sensu Welch 1982), Lygosominae (sensu Greer 1970a), Lygosomidae (sensu Hedges \& Conn 2012) and Lygosomiodea (sensu Hedges 2014), based on an incorrectly formed stem. The Greek neuter noun $\sigma 0 \mu \alpha$ (soma) has the stem somat- for formation of names in the family group (ICZN 1985: 217). However, in that Lygosominae and the alternatives have been in almost universal use (I can find only 15 uses of Lygosomatinae or alternative levels in the literature: Lang \& Böhme (1990); Nussbaum \& Raxworthy (1995); Stewart \& Thompson (1996, 2003, 2009a,b); Spawls \& Rotich (1997); Shine et al. (1998); Razzetti \& Mzuya (2002); Bourquin (2004); Stewart et al. (2009); Stewart \& Ecay (2010); Datta-Roy et al. (2013); Sánchez-Martínez et al. (2019), and Zhao et al. (2020), and one of these, Sánchez-Martínez et al. (2019), uses it inconsistently, with majority use of Lygosominae), under Article 56.2, the dominant spelling is to be retained (see also Allen et al. 2017). A search of the Zoological Record finds 73 uses of Lygosominae between 1979 and 2021, and three uses of Lygosomidae, while Google Scholar identifies over 1130 uses of Lygosominae and 27 uses of Lygosomidae (as of 4 May, 2021), and these numbers are by no means comprehensive, excluding much of the non-scientific literature. 
While the Code has rigid specifications for how the stem of a generic name is to be determined for formation of family-group names when the generic names are based on Greek or Latin words, the requirements are less precise for generic names that are arbitrary combinations of letters or based on words in languages other than Greek or Latin, and many of the generic names proposed by John Edward Gray are arbitrary combinations of letters rather than being based on Greek or Latin words. Those names that are combinations of letters and that have been involved in the creation of names in the family group are Chioninia, Dasia, Egernia, Feylinia, Ristella, Rhodona and Tiliqua. For names in this situation, the author of a family-group name can form the stem either using the entire genus name, the entire genus name with the ending elided, or the entire generic name with one or more appropriate linking letters incorporated to form a more euphonious family-group name (Article 29.3.3). Hence, the stems Chionini-, Dasi-, Egern-, Feylini-, Rhodon-, Ristell- and Tiliqu- (endings elided from the full generic name) are all acceptable for names proposed by Gray, de Vis, Cope, Hedges \& Conn, and Hedges, as well as Feylin- for the Feylinidae of Greer (1970a) and Egerni- for the Egerniini proposed by Welch (1982). Mabuya Fitzinger is from unspecified native languages of the Caribbean (Hedges \& Conn 2012), and hence Mabuy- is acceptable (as would have been Mabuya-).

The varying forms of Scincidae (Scincoides, Scincidia, Sincidae) have been discussed above where these names were introduced. As the names are all based on Scincus (or misspellings of Scincus), which is a Latin masculine

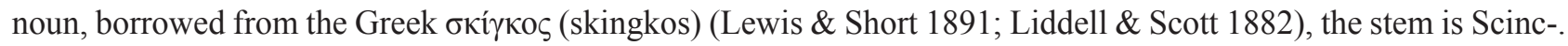

The remaining generic names from which family-group names by early authors were derived are either pure Greek nouns transliterated without change of termination, and hence taking the stem of the original Greek word (Article 29.3.1), or Greek nouns latinized with a change of termination, and hence taking the stem appropriate to the changed Latin ending (Article 29.3.2).

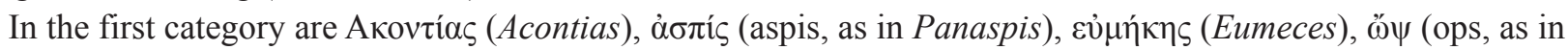
Anelytrops), $\varphi \omega \lambda i \varsigma$ (pholis, as in Lampropholis), $\tau \rho o ́ \pi ı \varsigma$ (tropis, as in Eutropis), and $\tau v \pi \lambda i v \eta \varsigma$ (Typhline). Despite the similarity, Anelytrops and Eutropis are derived from unrelated Greek words.

The genitive of acontias is acontiou, giving the stem aconti-, which would give the family-group name Acontiidae, as used by Cope (1864), not Acontinae/Acontidae, as subsequently used by Greer (1970a), Hedges \& Conn (2012) and Hedges (2014). There is extensive use of both -iidae/inae and -idea/inae in the recent literature. A Google Scholar search identified 11 uses of Acontiidae and 45 uses of Acontiinae against 14 uses of Acontidae and 171 uses of Acontinae. Hence, under one interpretation of Article 33.3.1, in which "prevailing" could be considered as the spelling in most frequent use no matter what the absolute numbers are, Acontidae and Acontinae, if treated as incorrect subsequent spellings, should not be rejected and should supplant the correct original spelling. An alternative nomenclatural view would be that as Greer (1970a), the first modern author to use Acontinae, did not provide any authority for that name, he was intending to use it as a new name, in which case he created a different family group name to that of Gray, based on a different (incorrectly formed) stem from the genus Acontias. This would make Acontiidae Gray (original spelling Acontiadae, corrected to Acontiidae by Cope 1864) and Acontinae Greer independent names based on different stems, with Acontinae being the junior synonym. Adopting this view would require the earlier name Acontiidae Gray 1839 to be used, as the use of both forms in the recent literature precludes use of Article 23.9 to reverse precedence.

Eumekes is a Greek adjective (meaning of good length or great) and would have the stem eumek-, giving Eumec- for the transliterated Eumeces).

While the genitives of aspis and pholis are respectively aspidos and pholidos, giving the stems aspid- and pholid- (and hence Panaspididiae and Lampropholididae), Article 29.3.1.1 allows for elision of the terminal letters -id from the stem. Thus, the elided stems would be Panasp- and Lamprophol-, giving Panaspini and Lampropholini for the two tribes created by Welch (1982), not Panaspiini and Lampropholiini, although neither have been subsequently used. Tropis is similarly formed, with Eutropides Fitzinger using the unelided stem Eutropid-.

There are no nomenclatural issues with the creation of Anelytropidae from a type genus Anelytrops, with the genitive of ops being opos, and the stem op-, or Typhlinidae from the type genus Typhline, with the genitive of typhline being typhlines, and the stem typhlin-

In the second category are blepharus (Ablepharus, Cryptoblepharus) from the Greek $\beta \lambda \varepsilon \dot{\varepsilon} \varphi \check{\rho} \rho \circ$ (blepharon $=$

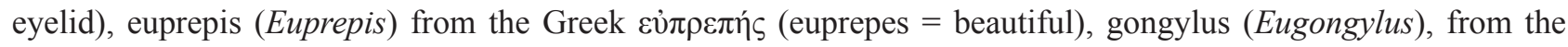

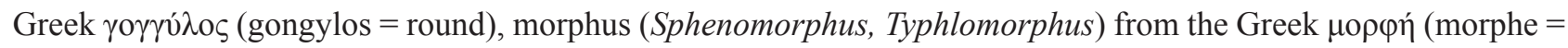
form), omorus (Ophiomorus), from the Greek ö

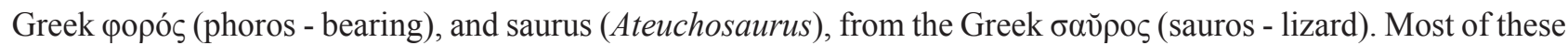


have been given a Latin masculine termination (Article 30.1.3), and have the stems (respectively) blephar-, gongyl-, morph-, omor- and saur- in their Latinised form (with gongylus being an adjective).

Euprepes is an adjective (the original Greek word meaning beautiful), but if treated as if it were a noun in its Latinised form (Article 11.8), the new termination provided could be considered as being that of a Latin third declension noun, of uncertain gender (male, common or feminine) as the word does not exist in Latin. Unfortunately, Wagler (1830) did not associate any adjectival species epithets in combination with Euprepis (all were used in combination with original generic combinations), precluding use of specific epithets to determine intended gender (Article 30.1.4.2). As a result, the name reverts to masculine gender, giving a genitive of euprepidis, and the stem euprepid-, or with the stem having the terminal id- elided, euprep-. Thus, the family-group name could be created as either Euprepididae, or Euprepidae. Fitzinger's use of Euprepae would thus become Euprepidae if the name were to be used.

Of the names coined by Hoser, those based on genera in turn based on Scincus (Adelynhoserscinciina, Adelynhoserscinciini, Asiascinciina, Culexlineatascinciina, Janetaescinciini, Sirenoscinciina, Sloppyscinciini, Sloppyscinciina, Starkeyscinciini, Starkeyscinciina), on morphus (Gongylomorphiini, Gongylomorphiina), on saurus (Typhlosauriina), and on meces (Eumeciini) have a stem scinc-, morph-, saur- and mec- and hence the -iini and -iina terminations provided by Hoser are incorrect, and would be required to be corrected should those names be used. However, most if not all of those names are either invalid (no diagnosis) or identify lineages that are unlikely to warrant recognition at the tribe or subtribe level or higher, and so correction is not needed. Acontinini is also incorrect, as noted above, while Paracontiina is correctly formed.

Scelotiina is derived from the genus Scelotes, which seems to be based on the Greek $\Sigma \kappa \varepsilon \lambda \mathrm{o}$ (leg) plus the

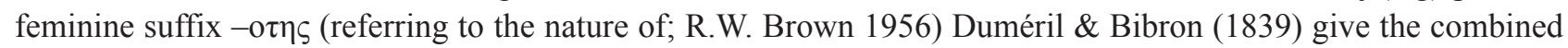
form $\Sigma \kappa \varepsilon \lambda 0 \tau \eta \varsigma$, with the meaning "which has only thighs or hind limbs", although the original author, Fitzinger (1826), does not give a derivation. In combined form, this would be a feminine third declension noun, for which

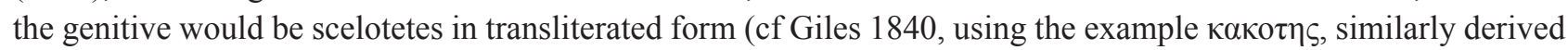

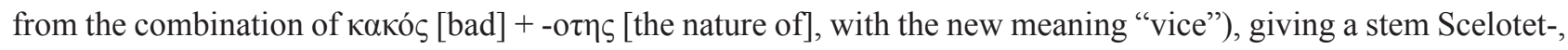
and a family name Scelotetidae. However, under Article 29.4, for a family-group name created after 1999, when a name is based on a Greek or Latin term but incorrectly formed, the original spelling is to be maintained provided the stem is treated as an arbitrary combination of letters (Article 29.4.2), in accordance with Article 29.3.3. Under the latter Article, the stem would be required to be one of three choices: the original full generic name (Scelotes-), the generic name with the termination elided (Scelot-) or the full generic name with one or more additional linking letters added to form a more euphonious family name (Scelotes- + linking letter(s)). Hence, Scelot- (the generic name with termination elided) is acceptable rather than the classically correct Scelotet-

Parabrachymeliini is from a type genus Parabrachymeles, itself based on Brachymeles. In creating the latter

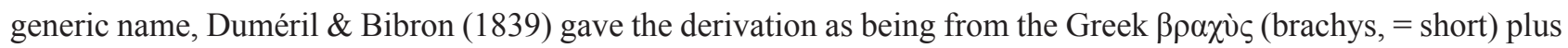
$\mu \varepsilon \dot{\lambda} \eta \eta$ (mele, = limbs), with the given meaning short limbs ("court et ...membres" in the original French). The Greek

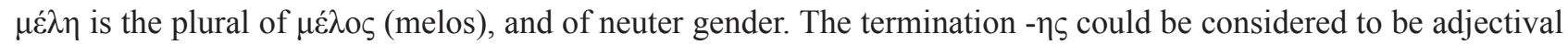
(masculine/feminine), meaning "short-limbed", and a genitive of $\mu \varepsilon ́ \lambda$ ov (L. Raty, pers. comm.). The gender of the original adjective Brachymeles is not defined by Duméril \& Bibron, who only combined with it the species name bonitae, a noun in the genitive case named for a ship. However, Duméril \& Bibron did create two other generic names for skinks on the immediately preceding pages, Heteromeles and Chelomeles with the same derivation from mele, and both considered to be masculine, being proposed in combination with masculine adjectival specific epithets (mauritanicus and quadrilineatus respectively). Hence, I consider Brachymeles to be masculine, and the stem for the family name would be Brachymel- (or in this case Parabrachymel-).

Nessia is one of the meaningless names coined by Gray, while Hakaria, as formed by Steindachner (1899) is based on the locality Hakari, a village on Socotra, and is not a Latin or Greek word. and hence it is up to Hoser to determine the stem. Under Article 29.3.3, the choices he could select from are the entire generic name, the entire generic name with the ending elided, or the entire generic name with one or more linking letters incorporated to form a more euphonious family-group name. Thus Nessiini, which could be considered based on Nessi-, and Hakariina, which could be considered based on Hakari-, are acceptable.

Funkiskinkus, presumably based on an Anglicised "skink" by Hoser, would have to be treated as a random combination of letters, and hence the stem is up to the original author, being either Funkiskinkus- or Funkiskink- + ina. However, Funkiskinki- + -ina is not acceptably formed, being both the termination elided plus an additional 
connecting vowel not present in the generic name. Given that all other authors have considered the entity named Funkiskinkus to be treated as part of the genus Plestiodon, without any need for a subtribe for part of Plestiodon, no emendation is as yet necessary.

\section{Relative priority of some names in the family group}

While most of the early family-group names within the Scincidae do not affect names in current usage, there are a few exceptions. Firstly, if Lygosominae/Lygosomidae/Lygosomoidea are attributed to Gray (1845, as Lygosomina), as assumed by Hedges (2014) rather than to Mittleman (1952) (and this is by assumption that Mittleman was aware of Gray's earlier name rather than independently coining a subfamily Lygosominae, based on what, until Mittleman's work, had been the largest genus of skinks, comprising $42.5 \%$ of the 374 species in the family in Boulenger's (1887) influential generic classification), then it antedates many of the other names associated with genera related to Lygosoma, leaving few priority issues. The stem is certainly the same (incorrectly formed in both cases). One issue remaining with Lygosomina Gray is that it was synchronously published with Tiliquina and Tropidophorina, each of which could equally apply to the more inclusive category that was termed the Lygosominae by Mittleman (1952) and Greer (1970a) and Lygosomoidea by Hedges (2014). I act in the sense of First Reviser under the Code to give priority to Lygosomina over Tiliquina and Tropidophorina when they are considered to represent the same higher taxon (Article 24.2).

Lygosominae Gray 1845 is antedated by the following family group names proposed by Fitzinger (1843): Ablephari, Cryptoblephari, Euprepae and Eutropides, as well as Rhodonidae Gray 1839. I do not consider Ophiopses Fitzinger, due to its unavailability because the type genus is a junior homonym (there is an additional complexity due to Ophiopses in the family-group being a senior homonym of Ophiopsidae Bartram 1975, based on Ophiopsis Agassiz 1834, but the unavailability of Ophiopses Fitzinger avoids the issue).

Due to the lengthy period of use of Lygosominae as one of the subfamilies of Scincidae by Greer (1970a) and subsequently as a superfamily Lygosomoidea by Hedges (2014), it is possible to invoke Article 23.9 to reverse precedence of the older names. Google Scholar reports 1130 uses of Lygosominae and 13 uses of Lygosomoidea, while Zoological Record cites 72 publications using Lygosominae. I specifically list the following 25 papers by more than 10 authors over the past 50 years that use Lygosominae to allow Article 23.9 to be used: Rawlinson (1974), Hardy (1979), Zweifel (1979), Ingram \& Ehmann (1981), Rieppel (1981), Blackburn (1982), Perret \& Wuest (1982), Greer (1986), Ouboter (1986), Hutchinson et al. (1990), Stewart \& Thompson (1994), Swain \& Jones (1997), R.M. Brown et al. (1999), Böhme et al. (2000), Honda et al. (2000), Mausfeld et al. (2002), Whiting et al. (2003), Brandley et al. (2005), Couper et al. (2005), J. Austin \& Arnold (2006), Goodman \& Isaac (2008), Harvey et al. (2008), C. Austin et al. (2010), Skinner et al. (2011), and Sadlier et al. (2015). This selection of papers covers all decades over the past 50 years, and with study species from most continents and nearby oceanic island groups inhabited by the Lygosominae. It also deliberately excludes the more recent, restricted use of the name Lygosominae/Lygosomidae to cover only a few genera (Hedges \& Conn 2012; Hedges 2014). In contrast, Ablephari, Cryptoblephari, Euprepae and Eutropides, either in their original form or in the modern form of Ablepharidae, Cryptoblepharidae, Euprepidae or Ophiopsidae (or -inae), have not been used since 1850.

The next issue is that there are three earlier family-group names for the taxon to which the names Sphenomorphini/Sphenomorpinae/Sphenomorphidae have been applied: Ablephari Fitzinger 1843, Rhodonidae Gray 1839 and Tropidophorini Gray 1845.

Due in part to the wide-spread distribution of the Sphenomorphini, across Australia, Pacific Oceania, East and South-east Asia and the Americas, and the high species diversity of this lineage, with many newly recently described species, resulting in a large number of papers dealing with members of the lineage, it is also possible to invoke Article 23.9 to reverse the relative priority of Rhodonidae and Sphenomorphini. While the majority of literature prior to Hedges \& Conn (2012) simply referred to this group by the informal name Sphenomorphus group of Greer (1979), there are a few uses of Sphenomorphini prior to 2012, and a number of uses of Sphenomorphinae and Sphenomorphidae following Hedges \& Conn (2012) sufficient to reach the requirement for 25 publications by 10 authors over the preceding 50 years, and over not less than 10 years. I have been able to locate the following 72 papers that use Sphenomorphidae ( $\mathrm{n}=52)$ : Hedges \& Conn (2012); Alvarado-Díaz et al. (2013); Ramírez-Bautista \& Cruz-Elizalde (2013); Zug (2013); Amey \& Worthington Wilmer (2014); Hedges (2014); Ramírez-Bautista et al. (2014, 2020); 
Solís et al. (2014); Sunyer (2014); Townsend (2014); Badillo-Saldaña et al. (2015); Johnson et al. (2015a,b, 2017); Lloyd (2015); Mata-Silva et al. (2015, 2019); Bahmani et al. (2016, 2018); Cruz Elizalde et al. (2016, 2019); Feizi et al. (2016); Goicoechea et al. (2016); Hofman et al. (2016); Reyes et al. (2016); Tenorio-Mendoza et al. (2016); Terán-Juárez et al. (2016); Vyas \& Parasharya (2016); Cruz-Sáenz et al. (2017a,b); Fraga-Ramírez et al. (2017); Gonzalez-Sanchez et al. (2017); Lorvelec et al. (2017); Paluh \& Bauer (2017); Prasopsin et al. (2017); Wilson et al. (2017); Woolrich- Piña et al. (2017); Berriozabal-Islas et al. (2018); García Grajales et al. (2018, 2019); Manhas et al. (2018); Medina-Fitoria et al. (2018); Contreras-Lozano et al. (2019); Galdamez et al. (2019); Hedges et al. (2019a); Krysko et al. (2019); Lazcano et al. (2019); McCranie et al. (2019); Sengupta et al. (2019); Čerňaňský \& Syromyatnikova (2021); L. Chen et al. (2021); Sphenomorphinae ( $\mathrm{n}=11)$ : Hitchmough et al. (2016); Rabosky et al. (2017); Title \& Rabosky (2017); Foster et al. (2018); Chapple et al. (2019, 2021); Leenders (2019); Thorn et al. (2019, 2021); M. Chen et al. (2020); O'Shea (2021) or Sphenomorphini ( $\mathrm{n}=9)$ : Welch (1983); Greer (2001, 2002); McAllister et al. (2014); Mead et al. (2014); Grismer et al. (2016); Batuwita (2019); Poyarkov et al. (2019); Shea (2019), and have found no uses of Ablephari (or that family-group name emended with a modern termination -idae, inae, ini or ina), Rhodonidae or Tropidophorina since the 1840s, and hence Ablephari (as Ablepharidae or equivalent at lower levels), Rhodonidae and Tropidophorina are nomina oblita. This does not preclude these names being used for sublineages of the Sphenomorphini in the future, should further subdivision be deemed necessary.

Similarly, Cryptoblephari Fitzinger 1843 and Eumecae Fitzinger 1843, neither in use since the middle of the $19^{\text {th }}$ century, antedate Eugongylini Welch 1982. While Eugongylini (or at higher levels Eugongylinae/Eugongylidae, the latter as used by Hedges \& Conn 2012), is in less common use than the equivalent lineage Sphenomorphini, there are still sufficient uses to be able to invoke Article 23.9, and as was the case for Sphenomorphini, there are a few uses prior to 2012 that allow for the citations to extend beyond 10 years. I have been able to identify 12 uses of Eugongylidae (Hedges \& Conn 2012; Zug 2013; Hedges 2014; W. Schmidt 2014; Bahmani et al. 2016, 2018; Jablonski 2016; Lorvelec et al. 2017; Paluh \& Bauer 2017; Čerňaňský et al. 2020; Speybroeck et al. 2020; Čerňaňský \& Syromyatnikova 2021), 27 uses of Eugongylinae (Safaei-Mahroo et al. 2015; Čerňaňský 2016; Chapple 2016a,b; Chapple \& Hitchmough 2016; Gartrell 2016; Hitchmough et al. 2016; Lettinck \& Hare 2016; Medina et al. 2016; Worthy 2016; Eftekharian et al. 2017; Worthy et al. 2017; Caldwell et al. 2018; Foster et al. 2018; Rahnama \& Jojati 2018; W. Branch et al. 2019; Ortiz et al. 2019; Thorn et al. 2019, 2021; Weinell et al. 2019; Bozkurt \& Olgun 2020; Hare et al. 2020; Bernstein et al. 2021; Chapple et al. 2021; L. Chen et al. 2021; O'Shea 2021; Patterson \& Hitchmough 2021) and three uses of Eugongylini (Greer 2001, 2002; Batuwita 2019).

The other name proposed by Gray (1845), Tiliquina, is more problematic. The Egerniini of Welch (1982), and the earlier Egernina of De Vis (1888), which need to be treated as independent due to the different stems employed in the formation of the names, apply to a much more geographically restricted (Australia, the Solomon Islands, New Guinea and the Maluku Archipelago of Indonesia) and less species-rich (62 species in 8 genera) lineage for which there have been many fewer uses of the terms Egerniini/Egerninae/Egernidae (although again the informal name Egernia group of Greer (1979) has a much greater usage). While I have been able to identify 40 uses of these names (with or without the double -i) since Welch (1982) created Egerniini (Egerniidae: Hedges \& Conn 2012; Pyron et al. 2013; Zug 2013; Hedges 2014; Sy 2015; Bahmani et al. 2016, 2018; Feizi et al. 2016; Paluh \& Bauer 2017; Čerňaňský et al. 2020; Čerňaňský \& Syromyatnikova 2021; Egerniinae: Hitchmough et al. 2016; Bull et al. 2017; Halliwell et al. 2017a-c; Atkins et al. 2018, 2020; Foster et al. 2018; Norval et al. 2018, 2021; Bower et al. 2019; Chapple et al. 2019, 2021; Ortiz et al. 2019; Thorn et al. 2019, 2021; Treilibs et al. 2019; While et al. 2019; Norval \& Gardner 2020; Pearson et al. 2020; Ridley et al. 2020; Stampe et al. 2020; Thompson et al. 2020; Watson et al. 2020, 2021; Frynta et al. 2021; O'Shea 2021; Riley et al. 2021 and van Blerk et al. 2021; no uses of Egernidae, Egerninae, Egerniini or Egernini), they have all been within the 10 years, from the point where Hedges \& Conn (2012) used the name (their paper was published 30 April 2012). This more limited time span precludes preserving Egerniinae or Egernina by reversal of precedence, and hence Tiliquina Gray 1845 needs to replace Egerniinae Welch 1982 and Egernina De Vis 1888 for the previous Egernia group of Greer (1979).

The use of family-group names based on Sphenomorphus shows an interesting difference in distribution to those based on Egernia, notwithstanding the geographic differences in distribution of those lineages. The most common use of Sphenomorphidae is for species lists based on local or regional faunal surveys, or checklists (36 of 72 citations), and most of those $(\mathrm{n}=33)$ are from central America and the Caribbean, areas which have only a single genus in the Sphenomorphidae, Scincella, and that represented by just a few species (usually one per survey). In 
contrast, the most common use of Egerniinae is for studies of species ecology (19 of 40), with no uses in checklists or faunal lists.

The name Eugongylinae/Eugongylidae also shows unique features in its pattern of use: several of the uses $(n=5)$ are specifically with respect to Ablepharus in West Asia, which Hedges (2014) incorrectly placed in his Eugongylidae, while many of the other uses specifically related to the lineage as represented in New Zealand ( $\mathrm{n}=11$, although seven of these are separately authored chapters from a single book). In contrast, there have been almost no uses of this family-group name with respect to Australia and surrounding islands, where the lineage is at its most diverse.

Of the names created by Mittleman (1952), Mabuyinae is potentially threatened by both Eutropides and Euprepae of Fitzinger (1843). Mabuyidae as resurrected by Hedges \& Conn (2012), like Eugongylidae, has had a span of use of less than 10 years, although in that time it has been frequently used, with Google Scholar listing 428 uses of Mabuyidae and 229 uses of Mabuyinae between 2012 and 2021. Luckily, there are two uses in the literature from the 1970s that use Mabuyinae following Mittleman (1952) rather than the subsequent taxonomic arrangement of Greer (1970a) that submerged Mabuyinae into the Lygosominae, and that extend the use of Mabuyidae/Mabuyinae beyond 10 years over the past half-century. I cite the following 25 papers by more than 10 authors over the period 1972-2021: Horton (1972); Murthy (1981); Miranda et al. (2012); Zug (2013); Hedges (2014); Solís et al. (2014); Sunyer (2014); Johnson et al. (2015a); Kemp \& Hadly (2015); Barré et al. (2016); Metallinou et al. (2016); Pereira \& Schrago (2017); Wilson et al. (2017); Novelli et al. (2018); Harrison et al. (2019); Hedges et al. (2019a,b); Weinell et al. (2019); Sengupta et al. (2019); McCranie et al. (2020); Pawar et al. (2020); Čerňaňský \& Syromyatnikova (2021); Chapple et al. (2021); O'Shea (2021); Silva et al. (2021).

\section{The taxonomic position of Eugongylus, type genus of the Eugongylini}

One recent phylogenetic meta-analysis, by Zheng \& Wiens (2016), recovered Eugongylus as nested within the Sphenomorphinae rather than the lineage to which the name Eugongylinae has consistently been applied. If accepted, this would result in the two names, proposed at the same time, being applied to the same lineage, and the lineage to which the name Eugongylinae had formerly applied having to change to an emended Cryptoblepharinae. However, the evidence for Eugongylus being a member of the Sphenomorphinae is very weak. Zheng \& Wiens (2016) recovered Eugongylus as sister to Isopachys, a reduce-limbed elongate sphenomorphine species with no morphological resemblance to Eugongylus. While there are 13 nodes between the placement of Eugongylus as sister to Isopachys and a placement on the base of the Eugongylidae in their tree, all of those nodes were very poorly supported (Shimodaira-Hasegawa-like support values of 0-18 for each node). The majority of the sequences used by Zheng \& Wiens (2016) were the same as used by Pyron et al. (2013) with the addition of additional sequences from Wiens et al. (2012). However, for skinks, the majority of the additional sequences were from scincine skinks, with only four lygosomines additionally sampled, E. rufescens, plus one species each from Sphenomorphus, Tiliqua and Trachylepis, for all of which received between 33 and 38 additional sequences. These additional sequences, with no additional sequence data for other eugongyline or sphenomorphine species, should have provided little opportunity for major changes in the placement of Eugongylus compared to the result of Pyron et al. (2013), who found Eugongylus to be basally placed within the Eugongylinae with strong support (Shimodaira-Hasegawa-like support of 100 for the node consisting of Eugongylus plus the remaining eugongylines). Other molecular studies agree with the placement recovered by Pyron et al. (2013), with Eugongylus either within the Eugongylinae, or closer to other lygosomines tribes than to the Sphenomorphini (Honda et al., 2000, 2003; Reeder, 2003; Whiting et al., 2003; Brandley et al., 2005; J. Austin \& Arnold, 2006; Smith et al., 2007; Skinner et al., 2011). Morphologically, Eugongylus is a eugongyline skink rather than a sphenomorphine skink (Greer, 1974, 1979; Greer \& Shea, 2001). Hence, I consider the placement recovered by Zheng \& Wiens (2016) to be a likely error, and retain Eugongylus within and Eugongylini for the lineage to which they are traditionally assigned.

Should the findings of Zheng \& Wiens (2016) be corroborated by multiple independent datasets, I act in the sense of First Revisor to give Sphenomorphini precedence over Eugongylini when both are considered to represent the same tribe, and note that Cryptoblepharini would become available for the tribe to which Eugongylini is currently applied. 


\section{The taxonomic position of Ablepharus, type genus of Fitzinger's Ablephari}

While Ablepharus (type species Scincus pannonicus Fitzinger 1824, now Ablepharus kitaibelii fitzingeri Mertens 1952 and not the senior synonym Ablepharus pannonicus (Lichtenstein 1823); see Bauer et al., 2003; Gemel \& Vergilov 2020) has generally been placed in the Sphenomorphini on morphological grounds (Greer 1974, 1979), two recent phylogenetic analyses have been equivocal about the placement of the genus. Both Pyron et al. (2013) and Zheng \& Wiens (2016) recovered A. pannonicus and Asymblepharus alaicus (Elpatjevsky 1901), the latter species formerly part of Ablepharus, but separated by Eremchenko and Szczerbak (1980), as basally positioned within the Sphenomorphini, but three other species of Ablepharus (A. budaki Göçmen et al. 1996, A. chernovi Darevsky 1953 and A. kitaibelii Bibron \& Bory 1833) as basally positioned within the Lygosomini (sensu stricto). Hedges (2014) placed all Ablepharus species in the Eugongylidae, but gave no reason for this placement — he may have misread the placement from Pyron et al. (2013). It is possible that this division of Ablepharus across separate lineages may be a sampling artefact. Examination of the sequences on which both analyses are based reveals that there are no shared sequences for the two groups. Ablepharus pannonicus and Asymblepharus alaicus are represented by a single shared sequence (ND2) along with Rag1 for A. alaicus and cMos for A. pannonicus, while the other three Ablepharus species are represented by $16 \mathrm{~S}$ sequences, with an additional $12 \mathrm{~S}$ sequence for $A$. kitaibelii only. The 16S samples were obtained from Poulakakis et al. (2005), while the ND2 sequences were obtained from Macey et al. (2006). Although Skourtanioti et al. (2016) included both pannonicus and the other three species in a single phylogenetic analysis (recovering pannonicus as the outgroup to the other species), they did not incorporate any other lygosomine skinks in their study, precluding assessment of their assignment to major lineages within the Lygosominae. Until both groups are represented by shared sequences in a broader analysis, I accept the position of Ablepharus in the Sphenomorphini, as reflected by morphology.

\section{Acontiinae Gray 1838, a senior homonym of Acontiinae Guenée 1841}

While this paper has primarily been concerned with the nomenclature of skink family group names, I note (see also Hedges 2014) that Acontiinae Gray 1839, a name in common use for a scincid lizard subfamily, is a senior homonym of Acontiinae Guenée 1841, a subfamily of noctuid moths (Lepidoptera: Noctuidae) and a name also in common use. Both names are based on the Greek word acontias. In the case of the skink subfamily, the name of the type genus is the full unaltered Greek word (see above). In the case of the moth subfamily, the generic name, created by Ochsenheimer (1816), in his Die Schmetterlinge von Europa, is Acontia. As was explicitly stated in a later volume in the series (Treitschke 1826), following Ochsenheimer's death in 1822, the generic name is based on the Greek word Acontias. In this case, the name was latinized with a change in termination, avoiding homonymy between the generic names Acontias Cuvier 1816 and Acontia Ochsenheimer 1816 [while Cuvier (1816) is usually cited as published in 1817, the year on the title page of that volume, it was released prior to December, 1816 fide Roux (1976)]. However, the genitive of the latinized acontia, having a feminine termination, would be acontiae, and the stem aconti-, as for the family-group name based on the original Greek acontias. Thus, both names in the family group have the same stem. Guenée's original spelling for the moth subfamily was Acontidi, but this has been subsequently given the correct family-group termination and Acontiinae has been used since. Under Article 55.3.1, this case must be referred to the International Commission on Zoological Nomenclature for a determination on how the junior homonym is to be altered to avoid homonymy. However, the most appropriate course (following Article 29.6) would be for the Commission to use the whole genus name Acontia, giving a subfamily Acontiainae for the moth subfamily (which coincidentally, is similar to Gray's original incorrectly spelt Acontiadae for the skink name). Bizarrely, Hoser (2015a) suggested that it might be the senior homonym, the scincid Acontinae, that might be unavailable, but this is clearly incorrect.

\section{Chalcidici Oppel 1811, a senior homonym of Chalcididae Latreille 1817}

A second homonymous name outside the Reptilia is also problematic. Latreille (1817) created a family name Chalcididae based on the wasp genus Chalcis Fabricius 1787. This is a name in common usage in the modern day. The Zoological Record lists 1951 uses of the name Chalcididae within Hymenoptera between 1864 and the time of writ- 
ing, and almost 26000 citations at the superfamily level (Chalcidoidea). Chalcididae Latreille is correctly formed from Chalcis, a Latin feminine noun, in turn derived without change in termination from the Greek feminine noun $\chi \alpha \lambda \kappa_{i} \zeta$ (chalkis), for which the genitive is chalkidos in the original Greek, giving the stem chalcid- in the latinized form, the same stem as for the skink genus Chalcides.

Chalcididae Latreille is a junior homonym of Chalidici Oppel. Chalcidici Oppel remains unused, unless Chalcidinae Mittleman (1952) is considered to be a resurrection of the same name, in which case both names have been used within the past century, precluding the use of Article 23.9 to reverse precedence. If, however, Chalcidinae Mittleman (1952) is considered an independently created name (a view that is easily justified, as no authors used Chalcididae in application to skinks between Oppel (1811) and Mittleman (1952), and Mittleman did not give any attribution for that name), then the lack of use of Chalcidici Oppel in the literature since 1811 would allow reversal of precedence to be invoked to maintain Latreille's family, with Chalcidinae Mittleman 1952 (as well as Chalcididae Gray 1825 (a synonym of Gymnophthalmidae) and Chalcidiini Hoser 2015b) being junior homonyms of both Chalcidici Oppel and Chalcididae Latreille.

To invoke Article 23.9, I list the following 25 papers by more than 10 authors over the past half-century that have used Chalcididae in the sense of Latreille: Joseph et al. (1972); Boucek (1974); Steffan (1976); Habu (1978); Simser \& Coppel (1980); Husain \& Agarwal (1982); Roy \& Farooqi (1984); Halstead (1986, 1990, 2000); Harendran (1988); Qian et al. (1992); Graham (1994); Rasplus \& Delvare (1996); Kerguelen \& Carde (1998); Marchiori et al. (2002); Ubaibillah \& Kojima (2004); Jennings (2006); Gupta \& Poorani (2008); Tinoco et al. (2012); Kazemi \& Loftalizadeh (2014); Prakash et al. (2016); Abul-Sood \& Gadallah (2018); Tavares et al. (2019), and Gadallah et al. (2020).

The conclusions of this paper may be summarized as the following classification.

\section{A new family-group classification and synonymy of skinks}

\section{Family Scincidae Oppel 1811}

Scincoides Oppel 1811: 20 (type genus Scincus Garsault 1764, by subsequent designation, this paper)

Scincidia Rafinesque 1815: 76 (type genus Scincus Daudin 1802, by presumption from inclusion of genus)

Sincidae Gray 1825: 201 (type genus Sincus Daudin 1802, by presumption from inclusion of genus; misspelling of Scincus Daudin)

Scincidae - Gray 1838c: 287 (corrected termination of Scincoides Oppel and Scincidia Rafinesque, and corrected spelling of Sincidae Gray)

Scincoidea Fitzinger 1826: 23 (type genus Scincus Daudin 1802, by presumption from inclusion of genus)

Scinci Wiegmann 1834a: 11 (type genus Scincus Fitzinger 1826, by presumption from inclusion of genus, = Scincus Daudin 1802)

Scincoidea-Hedges 2014: 319 (change in rank; homonym of Scincoidea Fitzinger 1826).

Chalcidici Oppel 1811: 41 (type genus Chalcides Brongniart 1800, by presumption as the earliest use of that name cited by Oppel $=$ Chalcides Laurenti 1768). Nomen oblitum.

Rhodonidae Gray 1839: 335 (type genus Rhodona Gray 1839, by presumption from inclusion of genus). Nomen oblitum.

Ablephari Fitzinger 1843: 23 (type genus Ablepharus Fitzinger 1824, explicitly).

Acontiadae Gray 1839: 336 (type genus Acontias Cuvier 1816, by presumption from inclusion of genus).

Acontiae Fitzinger 1843: 23 (type genus Acontias Cuvier 1816, explicitly).

CryptoblephariFitzinger 1843:23 (typegenus Cryptoblepharis [=Cryptoblepharus] Wiegmann 1834b, explicitly). Eumecae Fitzinger 1843: 22 (type genus Eumeces Wiegmann 1834a explicitly, but sensu Fitzinger 1843, by erroneous nomination of type species).

Euprepae Fitzinger 1843: 22 (type genus Euprepes Wagler 1830, explicitly).

Eutropides Fitzinger 1843: 22 (type genus Eutropis Fitzinger 1843, explicitly).

Ophiopses Fitzinger 1843: 23 (type genus Ophiopsis Fitzinger 1843 explicitly, = Lerista Bell 1833, non Ophiopsis Agassiz 1834). Not available due to homonymy of type genus.

Typhlomorphi Fitzinger 1843: 23 (type genus Typhlomorphus Fitzinger 1843, explicitly = Typhlosaurus Wiegmann 1834a).

Lygosomina Gray 1845: 74 (type genus Lygosoma Hardwicke \& Gray 1827, by presumption from inclusion of genus). 
Tiliquina Gray 1845: 102 (type genus Tiliqua Gray 1825, by presumption from inclusion of genus).

Tropidophorina Gray 1845: 100 (type genus Tropidophorus Duméril \& Bibron 1839, by presumption from inclusion of genus).

Typhlinidae Gray 1845: 128 (type genus Typhline Wiegmann 1834a = Typhlosaurus Wiegmann 1834a).

Ophiomoridae Gray 1845: 120 (type genus Ophiomorus Duméril \& Bibron 1839, by monotypy).

Opheomorinae Cope 1864: 228 (type genus Opheomorus, incorrect subsequent spelling of Ophiomorus Duméril \& Bibron 1839), incorrect subsequent spelling of Ophiomoridae Gray 1845.

Anelytropidae Cope 1864: 230 (type genus Anelytrops Duméril 1856 by presumption from inclusion of genus, = Feylinia Gray 1845). Replacement name for Typhlinidae Gray 1845. Non Anelytropsidae Camp 1923.

Feyliniidae Cope 1875: 20 (type genus Feylinia Gray 1845, by monotypy). Replacement name for Anelytropidae Cope 1864.

Egernina De Vis 1888: 813 (type genus Egernia Gray 1838c, by presumption from inclusion of genus).

Feyliniidae Camp 1923: 296 (type genus Feylinia Gray 1845, by presumption from inclusion of the genus).

Replacement name for Anelytropidae Cope 1864. Homonym of Feyliniidae Cope 1875.

Chalcidinae Mittleman 1952: 5 (type genus, by presumption due to the name being applied to a skink lineage, Chalcides Laurenti 1768; Scincidae, non Chalcides Daudin 1802; Gymnophthalmidae). Unavailable due to homonymy with Chalcididae Latreille 1817 (Hymenoptera).

Lygosominae Mittleman 1952: 4 (type genus Lygosoma Hardwicke \& Gray 1827, by presumption from inclusion of genus).

Mabuyinae Mittleman 1952: 4 (type genus Mabuya Fitzinger 1826, by presumption from stem of name).

Acontinae Greer 1970a: 158 (type genus Acontias Cuvier 1816, by presumption from inclusion of genus). Non Acontiadae Gray 1839.

Feylininae Greer 1970a: 155 (type genus Feylinia Gray 1845, by presumption from inclusion of genus). Non Feyliniidae Cope 1875 and Feyliniidae Camp 1923.

Egerniini Welch 1982: 26 (type genus Egernia Gray 1838c, by presumption from inclusion of genus). Non Egernina De Vis 1888.

Eugongylini Welch 1982: 26 (type genus Eugongylus Fitzinger 1843, by presumption from inclusion of genus). Sphenomorphini Welch 1982: 26 (type genus Sphenomorphus Fitzinger 1843 by presumption from inclusion of genus).

Lampropholiini Welch 1982: 26 (type genus Lampropholis Duméril \& Bibron 1839, by presumption from inclusion of genus).

Panaspiini Welch 1982: 26 (type genus Panaspis Cope 1868, by presumption from inclusion of genus).

Paracontiini Welch 1982: 25 (type genus Paracontias Mocquard 1894, by presumption due to being based on the former content of that genus).

Eumecinae Griffith, Ngo \& Murphy 2000: 9 (type genus Eumeces sensu Griffith et al. 2000 [= Plestiodon Duméril \& Bibron 1839], non Eumeces Wiegmann 1834a).

Chioniniinae Hedges \& Conn 2012: 29 (type genus Chioninia Gray 1845, explicitly).

Dasiinae Hedges \& Conn 2012: 29 (type genus Dasia Gray 1839, explicitly).

Trachylepidinae Hedges \& Conn 2012: 29 (type genus Trachylepis Fitzinger 1843, explicitly).

Ateuchosauridae Hedges 2014: 320 (type genus Ateuchosaurus Gray 1845 explicitly).

Ristellidae Hedges 2014: 321 (type genus Ristella Gray 1845, explicitly).

Acontinini Hoser 2015a: 9 (type genus Acontias Cuvier 1816, implicitly by statement of "terminal taxon", the type species of the genus). Non Acontiadae Gray, 1839.

Adelynhoserscinciini Hoser 2015a: 38 (type genus Adelynhoserscincus Hoser 2015a, implicitly by statement of "terminal taxon", the type species of the genus, = Plestiodon Duméril \& Bibron 1839).

Adelynhoserscinciina Hoser 2015a: 42 (type genus Adelynhoserscincus Hoser 2015a, implicitly by statement of "terminal taxon", the type species of the genus, = Plestiodon Duméril \& Bibron 1839).

Asiascinciina Hoser 2015a: 52 (type genus Asiascincus Hoser 2015a, implicitly by statement of "terminal taxon", the type species of the genus, = Plestiodon Duméril \& Bibron 1839).

Chalcidiina Hoser 2015b: 110 (type genus Chalcides Laurenti 1768, implicitly by statement of "terminal taxon", the type species of the genus, non Chalcides Daudin 1802; non Chalcidinae Mittleman 1952). Junior homonym of Chalcididae Latreille, 1817 (Hymenoptera). 
Culexlineatascinciina Hoser 2015a: 9 (type genus Culexlineatascincus Hoser 2015a, implicitly by statement of "terminal taxon", the type species of the genus = Mesoscincus Griffith et al. 2000).

Eumeciini Hoser 2015a: 38, 54 (type genus Eumeces Wiegmann 1834a, implicitly by statement of "terminal taxon", the type species of the genus). Non Eumecae Fitzinger 1843, non Eumecini Griffith et al. 2000. Not available under Article 13.1.

Feyliniini Hoser 2015b: 114 (type genus Feylinia Gray 1845, implicitly by statement of "terminal taxon", the type species of the genus). Junior homonym of Feyliniidae Cope 1875 and Feyliniidae Camp 1923. Not available under Article 13.1.

Funkiskinkiina Hoser 2015a: 47 (type genus Funkiskinkus Hoser 2015a, implicitly by statement of "terminal taxon", the type species of the genus, = Plestiodon Duméril \& Bibron 1839).

Gongylomorphiini Hoser 2015b: 109 (type genus Gongylomorphus Fitzinger 1843, implicitly by statement of "terminal taxon", the type species of the genus).

Gongylomorphiina Hoser 2015b: 109, 110 (type genus Gongylomorphus Fitzinger 1843, implicitly by statement of "terminal taxon", the type species of the genus).

Hakariina Hoser 2015b: 111, 113 (type genus Hakaria Steindachner 1899, implicitly by statement of "terminal taxon", the type species of the genus).

Janetaescinciini Hoser 2015a: 55 (type genus Janetaescincus Greer 1970c, implicitly by statement of "terminal taxon", the type species of the genus). Not available under Article 13.1).

Nessiini Hoser 2015b: 114 (type genus Nessia Gray 1845, implicitly by statement of "terminal taxon", the type species of the genus).

Parabrachymeliini Hoser 2015a: 15 (type genus Parabrachymeles Hoser 2015a, implicitly by statement of "terminal taxon", the type species of the genus, = Brachymeles Duméril \& Bibron 1839).

Paracontiina Hoser 2015b: 110, 113 (type genus Paracontias Mocquard 1894, implicitly by statement of "terminal taxon", the type species of the genus; junior homonym of Paracontiini Welch 1982). Not available under Article 13.1.

Scelotiina Hoser 2015b: 111, 114 (type genus Scelotes Fitzinger 1826, implicitly by statement of "terminal taxon", the type species of the genus). Not available under Article 13.1.

Sirenoscinciina Hoser 2015b: 111, 113 (type genus Sirenoscincus Sakata \& Hikida 2003, implicitly by statement of "terminal taxon", the type species of the genus, =Voeltzkowia Boettger 1893, fide Miralles et al. 2015).

Sloppyscinciini Hoser 2015b: 110 (type genus Sloppyscincus Hoser 2015b, implicitly by statement of "terminal taxon", the type species of the genus). Not available under Article 13.1.

Sloppyscinciina Hoser 2015b: 110, 112 (type genus Sloppyscincus Hoser 2015b, implicitly by statement of "terminal taxon", the type species of the genus). Not available under Article 13.1.

Starkeyscinciini Hoser 2015a: 13 (type genus Starkeyscincus Hoser 2015a, implicitly by statement of "terminal taxon", the type species of the genus, = Ophiomorus Duméril \& Bibron 1839).

Starkeyscinciina Hoser 2015a: 13 (type genus Starkeyscincus Hoser 2015a, implicitly by statement of "terminal taxon", the type species of the genus, = Ophiomorus Duméril \& Bibron 1839).

Typhlosauriina Hoser 2015a: 9 (type genus Typhlosaurus Wiegmann 1834a, implicitly by statement of "terminal taxon", the type species of the genus).

\section{Subfamily Scincinae Oppel 1811}

Scincoides Oppel 1811: 20 (type genus Scincus Garsault 1764, by subsequent designation, this paper) Scincidia Rafinesque 1815: 76 (type genus Scincus Daudin 1802, by presumption from inclusion of genus) Sincidae Gray 1825: 201 (type genus Sincus Daudin 1802, by presumption from inclusion of genus; misspelling of Scincus Daudin)

Scincina-Gray 1845: 70 (change in rank).

Scincinae-Mittleman 1952: 5 (change in rank).

Ophiomoridae Gray 1845: 120 (type genus Ophiomorus Duméril \& Bibron 1839, by monotypy).

Opheomorinae Cope 1864: 228 (type genus Opheomorus, incorrect subsequent spelling of Ophiomorus Duméril \& Bibron 1839), incorrect subsequent spelling of Ophiomoridae Gray 1845.

Anelytropidae Cope 1864: 230 (type genus Anelytrops Duméril 1856 by presumption from inclusion of genus, = Feylinia Gray 1845). Replacement name for Typhlinidae Gray 1845. Non Anelytropsidae Camp 1923. 
Feyliniidae Cope 1875: 20 (type genus Feylinia Gray 1845, by monotypy). Replacement name for Anelytropidae Cope 1864.

Feyliniidae Camp 1923: 296 (type genus Feylinia Gray 1845, by presumption from inclusion of the genus). Replacement name for Anelytropidae Cope 1864. Homonym of Feyliniidae Cope 1875.

Chalcidinae Mittleman 1952: 5 (type genus, by presumption due to the name being applied to a skink lineage, Chalcides Laurenti 1768; Scincidae, non Chalcides Daudin 1802; Gymnophthalmidae). Unavailable due to homonymy with Chalcididae Latreille 1817 (Hymenoptera).

Feylininae Greer 1970a: 155 (type genus Feylinia Gray 1845, by presumption from inclusion of genus). Non Feyliniidae Cope 1875 and Feyliniidae Camp 1923.

Paracontiini Welch 1982: 25 (type genus Paracontias Mocquard 1894, by presumption due to being based on the former content of that genus).

Eumecinae Griffith, Ngo \& Murphy 2000: 9 (type genus Eumeces sensu Griffith et al. 2000 [= Plestiodon Duméril \& Bibron 1839], non Eumeces Wiegmann 1834a).

Adelynhoserscinciini Hoser 2015a: 38 (type genus Adelynhoserscincus Hoser 2015a, implicitly by statement of "terminal taxon", the type species of the genus, = Plestiodon Duméril \& Bibron 1839).

Adelynhoserscinciina Hoser 2015a: 42 (type genus Adelynhoserscincus Hoser 2015a, implicitly by statement of "terminal taxon", the type species of the genus, = Plestiodon Duméril \& Bibron 1839).

Asiascinciina Hoser 2015a: 52 (type genus Asiascincus Hoser 2015a, implicitly by statement of "terminal taxon", the type species of the genus, = Plestiodon Duméril \& Bibron 1839).

Chalcidiina Hoser 2015b: 110 (type genus Chalcides Laurenti 1768, implicitly by statement of "terminal taxon", the type species of the genus, non Chalcides Daudin 1802; non Chalcidinae Mittleman 1952). Junior homonym of Chalcididae Latreille, 1817 (Hymenoptera).

Culexlineatascinciina Hoser 2015a: 9 (type genus Culexlineatascincus Hoser 2015a, implicitly by statement of "terminal taxon", the type species of the genus = Mesoscincus Griffith et al. 2000).

Eumeciini Hoser 2015a: 38, 54 (type genus Eumeces Wiegmann 1834a, implicitly by statement of "terminal taxon", the type species of the genus). Non Eumecae Fitzinger 1843, non Eumecini Griffith et al. 2000. Not available under Article 13.1.

Feyliniini Hoser 2015b: 114 (type genus Feylinia Gray 1845, implicitly by statement of "terminal taxon", the type species of the genus). Junior homonym of Feyliniidae Cope 1875 and Feyliniidae Camp 1923. Not available under Article 13.1.

Funkiskinkiina Hoser 2015a: 47 (type genus Funkiskinkus Hoser 2015a, implicitly by statement of "terminal taxon", the type species of the genus, = Plestiodon Duméril \& Bibron 1839).

Gongylomorphiini Hoser 2015b: 109 (type genus Gongylomorphus Fitzinger 1843, implicitly by statement of "terminal taxon", the type species of the genus).

Gongylomorphiina Hoser 2015b: 109, 110 (type genus Gongylomorphus Fitzinger 1843, implicitly by statement of "terminal taxon", the type species of the genus).

Hakariina Hoser 2015b: 111, 113 (type genus Hakaria Steindachner 1899, implicitly by statement of "terminal taxon", the type species of the genus).

Janetaescinciini Hoser 2015a: 55 (type genus Janetaescincus Greer 1970c, implicitly by statement of "terminal taxon", the type species of the genus). Not available under Article 13.1).

Nessiini Hoser 2015b: 114 (type genus Nessia Gray 1845, implicitly by statement of "terminal taxon", the type species of the genus).

Parabrachymeliini Hoser 2015a: 15 (type genus Parabrachymeles Hoser 2015a, implicitly by statement of "terminal taxon", the type species of the genus, = Brachymeles Duméril \& Bibron 1839).

Paracontiina Hoser 2015b: 110, 113 (type genus Paracontias Mocquard 1894, implicitly by statement of "terminal taxon", the type species of the genus; junior homonym of Paracontiini Welch 1982). Not available under Article 13.1.

Scelotiina Hoser 2015b: 111, 114 (type genus Scelotes Fitzinger 1826, implicitly by statement of "terminal taxon", the type species of the genus). Not available under Article 13.1.

Sirenoscinciina Hoser 2015b: 111, 113 (type genus Sirenoscincus Sakata \& Hikida 2003, implicitly by statement of "terminal taxon", the type species of the genus, = Voeltzkowia Boettger 1893, fide Miralles et al. 2015).

Sloppyscinciini Hoser 2015b: 110 (type genus Sloppyscincus Hoser 2015b, implicitly by statement of "terminal 
taxon", the type species of the genus). Not available under Article 13.1.

Sloppyscinciina Hoser 2015b: 110, 112 (type genus Sloppyscincus Hoser 2015b, implicitly by statement of "terminal taxon", the type species of the genus). Not available under Article 13.1.

Starkeyscinciini Hoser 2015a: 13 (type genus Starkeyscincus Hoser 2015a, implicitly by statement of "terminal taxon", the type species of the genus, = Ophiomorus Duméril \& Bibron 1839).

Starkeyscinciina Hoser 2015a: 13 (type genus Starkeyscincus Hoser 2015a, implicitly by statement of "terminal taxon", the type species of the genus, = Ophiomorus Duméril \& Bibron 1839).

\section{Subfamily Acontiinae Gray 1839}

Acontiadae Gray 1839: 336 (type genus Acontias Cuvier 1816, by presumption from inclusion of genus).

Acontiidae-Cope 1864: 230 (corrected spelling of Acontiadae Gray 1839).

Acontidae-Hedges \& Conn 2012: 28 (altered stem of Acontiadae Gray 1839, by conflation with Acontinae Greer 1970a).

Acontoidea-Hedges 2014: 319 (change in rank of Acontiadae Gray, with erroneously altered stem).

Acontiae Fitzinger 1843: 23 (type genus Acontias Cuvier 1816, explicitly).

Typhlomorphi Fitzinger 1843: 23 (type genus Typhlomorphus Fitzinger 1843, explicitly = Typhlosaurus Wiegmann 1834a).

Typhlinidae Gray 1845: 128 (type genus Typhline Wiegmann 1834a = Typhlosaurus Wiegmann 1834a).

Acontinae Greer 1970a: 158 (type genus Acontias Cuvier 1816, by presumption from inclusion of genus). Non Acontiadae Gray 1839.

Acontinini Hoser 2015a: 9 (type genus Acontias Cuvier 1816, implicitly by statement of "terminal taxon", the type species of the genus). Non Acontiadae Gray 1839.

Typhlosauriina Hoser 2015a: 9 (type genus Typhlosaurus Wiegmann 1834a, implicitly by statement of "terminal taxon", the type species of the genus).

\section{Subfamily Lygosominae Gray 1845}

Lygosomina Gray 1845: 74 (type genus Lygosoma Hardwicke \& Gray 1827, by presumption from inclusion of genus).

Lygosomoidea-Hedges 2014: 319 (change of rank of Lygosominae Gray 1845).

Lygosomidae-Hedges \& Conn 2012: 28 (change in rank of Lygosominae Gray 1845).

Lygosominae Mittleman 1952: 4 (type genus Lygosoma Hardwicke \& Gray 1827, by inclusion of genus).

Lygosomini-Welch 1982: 26 (change of rank of Lygosominae Mittleman 1952).

Rhodonidae Gray 1839: 335 (type genus Rhodona Gray 1839, by presumption from inclusion of genus). Nomen oblitum.

Ablephari Fitzinger 1843: 23 (type genus Ablepharus Fitzinger 1824, explicitly). Nomen oblitum.

Cryptoblephari Fitzinger 1843: 23 (type genus Cryptoblepharis [=Cryptoblepharus] Wiegmann 1834b, explicitly). Nomen oblitum.

Eumecae Fitzinger 1843: 22 (type genus Eumeces Wiegmann 1834a explicitly, but sensu Fitzinger 1843, by erroneous nomination of type species). Nomen oblitum.

Euprepae Fitzinger 1843: 22 (type genus Euprepes Wagler 1830, explicitly). Nomen oblitum.

Eutropides Fitzinger 1843: 22 (type genus Eutropis Fitzinger 1843, explicitly). Nomen oblitum.

Ophiopses Fitzinger 1843: 23 (type genus Ophiopsis Fitzinger 1843 explicitly, = Lerista Bell 1833, non Ophiopsis Agassiz 1834). Not available due to homonymy of type genus.

Tropidophorina Gray 1845: 100 (type genus Tropidophorus Duméril \& Bibron 1839, by presumption from inclusion of genus). Nomen oblitum.

Tiliquina Gray 1845: 102 (type genus Tiliqua Gray 1825, by presumption from inclusion of genus).

Egernina De Vis 1888: 813 (type genus Egernia Gray 1838c, by presumption from inclusion of genus).

Mabuyinae Mittleman 1952: 4 (type genus Mabuya Fitzinger 1826, by presumption from stem of name).

Egerniini Welch 1982: 26 (type genus Egernia Gray 1838c, by presumption from inclusion of genus). Non Egernina De Vis 1888.

Eugongylini Welch 1982: 26 (type genus Eugongylus Fitzinger 1843, by presumption from inclusion of genus). Sphenomorphini Welch 1982: 26 (type genus Sphenomorphus Fitzinger 1843 by presumption from inclusion of 
genus).

Lampropholiini Welch 1982: 26 (type genus Lampropholis Duméril \& Bibron 1839).

Lampropholiini Welch 1982: 26 (type genus Lampropholis Duméril \& Bibron 1839, by presumption from inclusion of genus).

Chioniniinae Hedges \& Conn 2012: 29 (type genus Chioninia Gray 1845, explicitly).

Dasiinae Hedges \& Conn 2012: 29 (type genus Dasia Gray 1839, explicitly).

Trachylepidinae Hedges \& Conn 2012: 29 (type genus Trachylepis Fitzinger 1843, explicitly).

Ateuchosauridae Hedges 2014: 320 (type genus Ateuchosaurus Gray 1845).

Ristellidae Hedges 2014: 321 (type genus Ristella Gray, 1845, explicitly).

\section{Tribe Lygosomini Gray 1845}

Lygosomina Gray 1845: 74 (type genus Lygosoma Hardwicke \& Gray 1827, by presumption from inclusion of genus).

Lygosomidae-Hedges \& Conn 2012: 28 (change in rank of Lygosominae Gray 1845).

Lygosominae Mittleman 1952: 4 (type genus Lygosoma Hardwicke \& Gray 1827, by presumption from inclusion of genus).

Lygosomini-Welch 1982: 26 (change of rank of Lygosominae Mittleman 1952).

\section{Tribe Ateuchosaurini Hedges 2014}

Ateuchosauridae Hedges 2014: 320 (type genus Ateuchosaurus Gray 1845 explicitly).

\section{Tribe Tiliquini Gray 1845}

Tiliquina Gray 1845: 102 (type genus Tiliqua Gray 1825, by presumption from inclusion of genus).

Egernina De Vis 1888: 813 (type genus Egernia Gray 1838c, by presumption from inclusion of genus).

Egerniini Welch 1982: 26 (type genus Egernia Gray 1838c, by presumption from inclusion of genus). Non Egernina De Vis 1888.

Egerniidae-Hedges \& Conn 2012: 28 (change in rank of Egerniinae Welch 1982).

Egerniinae-Hitchmough et al. 2016: 88 (change in rank of Egerniinae Welch 1982).

\section{Tribe Eugongylini Welch 1982}

Eugongylini Welch 1982: 26 (type genus Eugongylus Fitzinger 1843, by presumption from inclusion of genus). Nomen protectum.

Eugongylidae-Hedges \& Conn 2012: 28 (change in rank of Eugongylini Welch 1982).

Cryptoblephari Fitzinger 1843: 23 (type genus Cryptoblepharis [=Cryptoblepharus] Wiegmann 1834b, explicitly). Nomen oblitum.

Eumecae Fitzinger 1843: 22 (type genus Eumeces Wiegmann 1834a explicitly, but sensu Fitzinger 1843, by erroneous nomination of type species). Nomen oblitum.

Lampropholiini Welch 1982: 26 (type genus Lampropholis Duméril \& Bibron 1839, by presumption from inclusion of genus).

Panaspiini Welch 1982: 26 (type genus Panaspis Cope 1868, by presumption from inclusion of genus).

\section{Tribe Ristellini Hedges 2014}

Ristellidae Hedges 2014: 321 (type genus Ristella Gray 1845, explicitly).

\section{Tribe Sphenomorphini Welch 1982}

Sphenomorphini Welch 1982: 26 (type genus Sphenomorphus Fitzinger 1843 by presumption from inclusion of genus). Nomen protectum.

Sphenomorphidae-Hedges \& Conn 2012: 28 (change in rank of Sphenomorphini Welch 1982).

Sphenomorphinae-Hitchmough et al. 2016: 94 (change in rank of Sphenomorphini Welch 1982).

Ablephari Fitzinger 1843: 23 (type genus Ablepharus Fitzinger 1824, explicitly). Nomen oblitum.

Ophiopses Fitzinger 1843: 23 (type genus Ophiopsis Fitzinger 1843 explicitly, =Lerista Bell 1833, non Ophiopsis Agassiz 1834). Not available due to homonymy of type genus. 
Rhodonidae Gray 1839: 335 (type genus Rhodona Gray 1839, by presumption from inclusion of genus). Nomen oblitum.

Tropidophorina Gray 1845: 100 (type genus Tropidophorus Duméril \& Bibron 1839, by presumption from inclusion of genus). Nomen oblitum.

\section{Tribe Mabuyini Mittleman 1952}

Mabuyinae Mittleman 1952: 4 (type genus Mabuya Fitzinger 1826, by presumption from stem of name). Nomen protectum.

Mabuyidae-Hedges \& Conn 2012: 28 (change in rank of Mabuyinae Mittleman 1982).

Euprepae Fitzinger 1843: 22 (type genus Euprepes Wagler 1830, explicitly). Nomen oblitum.

Eutropides Fitzinger 1843: 22 (type genus Eutropis Fitzinger 1843, explicitly). Nomen oblitum.

Lygosomini Welch 1982: 26 (part).

Chioniniinae Hedges \& Conn 2012: 29 (type genus Chioninia Gray 1845, explicitly).

Dasiinae Hedges \& Conn 2012: 29 (type genus Dasia Gray 1839, explicitly).

Trachylepidinae Hedges \& Conn 2012: 29 (type genus Trachylepis Fitzinger 1843, explicitly).

\section{Acknowledgements}

I thank Peter Shea for discussion of a number of points of Latin and Greek grammar, and Laurent Raty, Cristian Ruiz Altaba, Evangelos Vlachos and Doug Yanega for their assistance with the problematic Brachymeles. Neal Evenhuis generously discussed interpretation of certain Articles of the Code and located some critical references, and Aaron Bauer checked a number of reference citations

\section{References}

Abul-Sood, M.I. \& Gadallah, N.S. (2018) New records of the family Chalcididae (Hymenoptera: Chalcidoidea) from Egypt. Zootaxa, 4410 (1), 136-146. https://doi.org/10.11646/zootaxa.4410.1.7

Adler, K. (2012) Herpetological exploration in the $18^{\text {th }}$ Century: spanning the globe with Linnaeus's students. Bibliotheca Herpetologica, $9(1-2), 39-52$.

Agassiz, L. (1834) Abgerissene Bemerkungen über fossile Fische. Neues Jahrbuch für Mineralogie, Geognosie, Geologie und Petrefaktenkunde, 1834, 379-390.

Allen, K.E., Tapondjou N, W.P., Welton, L.J. \& Bauer, A.M. (2017) A new species of Trachylepis (Squamata: Scincidae) from Central Africa and a key to the Trachylepis of West and Central Africa. Zootaxa, 4268 (2), 255-269. https://doi.org/10.11646/zootaxa.4268.2.5

Alvarado-Díaz, J., Suazo-Ortuño, I., Wilson, L.D. \& Medina-Aguilar, O. (2013) Patterns of physiographic distribution and conservation status of the herpetofauna of Michoacán, Mexico. Amphibian \& Reptile Conservation, 7 (1), 128-170.

Amey, A.P. \& Worthington Wilmer, J. (2014) Morphological diversity and genetic structure within Lerista kalumburu Storr, 1976 (Squamata: Scincomorpha: Sphenomorphidae) — taxonomic implications. Zootaxa, 3821 (2), 239-252. https://doi.org/10.11646/zootaxa.3821.2.4

Anderson, S.C. (1999) The lizards of Iran. Society for the Study of Amphibians and Reptiles, Ithaca, New York, vii + 442 pp.

Annandale, N. (1917) A new genus of limbless skinks from an island in the Chilka Lake. Records of the Indian Museum, 13 (1), $17-21$. https://doi.org/10.5962/bhl.part.5856

Anonymous (1925) Opinion 89. Suspension of the Rules in the Case of Gronow 1763, Commerson 1803, Gesellschaft Schauplatz 1775 to 1781, Catesby 1771, Browne 1789, Valmont de Bomare 1768 to 1775. Smithsonian Miscellaneous Collections, 73 (3), 27-33.

Arnold, E.N. \& Leviton, A.E. (1977) A revision of the lizard genus Scincus (Reptilia: Scincidae). Bulletin of the British Museum (Natural History). Zoology, 31 (5), 187-248, pls. 1-3.

Atkins, Z.S., Clemann, N., Schroder, M., Chapple, D.G., Davis, N.E., Robinson, W.A., Wainer, J. \& Robert, K.A. (2018) Consistent temporal variation in the diet of an endangered alpine lizard across two south-eastern Australian sky-islands. Austral Ecology, 43 (3), 339-351. https://doi.org/10.1111/aec.12572

Atkins, Z.S., Clemann, N., Chapple, D.G., Edwards, A.M., Sinsch, U., Hantzschmann, A.M., Schroder, M., Scroggie, M.P. \& Robert, K.A. (2020) Demographic and life history variation in two sky-island populations of an endangered alpine lizard. 
Journal of Zoology, 310 (1), 34-44.

https://doi.org/10.1111/jzo.12728

Austin, C.C., Rittmeyer, E.N., Richards, S.J. \& Zug, G.R. (2010) Phylogeny, historical biogeography and body size evolution in Pacific Island Crocodile Skinks Tribolonotus (Squamata, Scincidae). Molecular Phylogenetics and Evolution, 57 (1), 227-236.

https://doi.org/10.1016/j.ympev.2010.06.005

Austin, J.J. \& Arnold, E.N. (2006) Using ancient and recent DNA to explore relationships of extinct and endangered Leiolopisma skinks (Reptilia: Scincidae) in the Mascarene islands. Molecular Phylogenetics and Evolution, 39, 503-511. https://doi.org/10.1016/j.ympev.2005.12.011

Badillo-Saldaña, L.M., Ramírez-Bautista, A., Lara-Tufiño, D. \& Berriozabal-Islas, C. (2015) Diversity and conservation status of the herpetofauna for an area from north of Hidalgo, Mexico. Cuadernos de Herpetologia, 29 (2), 131-139.

Bahmani, Z., Rastegar-Pouyani, N. \& Rastegar-Pouyani, E. (2016) Systematics of the genus Trachylepis Fitzinger, 1843 (Sauria: Scincidae) with special reference to the Middle East: a review. Iranian Journal of Animal Biosystematics, 12 (2), 211-224.

Bahmani, Z., Rastegar-Pouyani, E. \& Rastegar-Pouyani, N. (2018) The phylogenetic relationships and molecular systematics of scincid lizards of the genus Heremites (Sauria, Scincidae) in the Middle East based on mtDNA sequences. Mitochondrial DNA, Part A, 29 (6), 846-855.

https://doi.org/10.1080/24701394.2017.1373107

"Balk, L." [Linnaeus, C.] (1746) Museum Adolpho-Fridericianum, quod, cum consensu ampliss. Fac. Medicae in Regia Acad. Upsaliensi, sub Praesido viri celeberrimi, D.D. Caroli Linnaei. Laurentii Salvii, Holmiae, [vii] + 48 pp., [2 pls.].

"Balk, L." [Linnaeus, C.] (1749) Museum Adopho-Fridericianum sub praesidio Dn. D. Caroli Linnaei. In: Amoenitates Academicae seu dissertationes variae Physicae, Medicae Botanicae antehac seorsim editae nunc collectae et auctae cum tabulis aeneis. Volumen Primum. Godofredum Kiesewetter, Holmiae et Lipsiae, pp. 277-327, pls. 13-14.

Barboza du Bocage, J.V. (1866) Reptiles nouveaux ou peu connus recueillis dans les possessions portugaises de l'Afrique occidentale, qui se trouvent au Muséum de Lisbonne. Jornal de Sciencias Mathematicas Physicas e Naturaes, Lisboa, 1, 57-78, pl. 1.

Barboza du Bocage, J.V. (1870) Description d'un $<<$ Saurien $>>$ nouveau de 1'Afrique occidentale. Jornal de Sciencias Mathematicas Physicas e Naturaes, Lisboa, 3 (9), 66-68, pl. 1.

Barboza du Bocage, J.V. (1873a) Note sur l'habitat et les caractères zoologiques du $<<$ Macroscincus Coctei $>>(<<$ Euprepes coctei. >> Dum. Bibr.). Jornal de Sciencias Mathematicas Physicas e Naturaes, Lisboa, 4 (16), 295-306.

Barboza du Bocage, J.V. (1873b) Mélanges erpétologiques. II. Sur quelques Reptiles et Batraciens nouveaux, rares ou peu connus d'Afrique occidentale. Jornal de Sciencias Mathematicas Physicas e Naturaes, Lisboa, 4 (15), $209-227$.

Barboza du Bocage, J.V. (1889) Mélanges erpétologiques. I.-Sur un Scincoidien nouveau de Madagascar. Jornal de Sciencias Mathematicas, Physicas e Naturaes, Lisboa, Series 2, 1 (2), 125-126.

Barré, N., Trillot, A. \& Lorvelec, O. (2016) Skinks occur on Terre-de-Bas, Les Saintes (Guadeloupe, French West Indies). Caribbean Herpetology, 56, 1-2. https://doi.org/10.31611/ch.56

Bartram, A.W.H. (1975) The holostean fish genus Ophiopsis Agassiz. Zoological Journal of the Linnean Society, 56, $183-502$. https://doi.org/10.1111/j.1096-3642.1975.tb00263.x

Bates, M.F. (1988) Typhlosaurus lineatus lineatus (Boulenger, 1887). Journal of the Herpetological Association of Africa, 34 , 50 .

Bates, M.F., Heideman, N.J.L., Wilson, B.A., Hendricks, M.G.J., Don, N. \& Moses, C. (1998) Morphological variation and geographical distribution in the South African lizards Typhlosaurus caecus (Cuvier 1817) and Typhlosaurus vermis Boulenger 1887 (Scincidae: Acontinae). African Journal of Herpetology, 47 (2), 35-41. https://doi.org/10.1080/21564574.1998.9650001

Batuwita, S. (2019) A review of the lizards of the endemic genus Lankascincus (Reptilia: Scincidae: Lygosominae) from Sri Lanka. Bulletin of the Museum of Comparative Zoology, 162 (3), 211-262. https://doi.org/10.3099/MCZ38.1

Bauer, A.M. (2013) On the identity of Lacerta punctata Linnaeus 1758, the type species of the genus Euprepis Wagler 1830, and the generic assignment of Afro-Malagasy skinks. African Journal of Herpetology, 52 (1), 1-7. https://doi.org/10.1080/21564574.2003.9635472

Bauer, A.M. (2014a) Typhlosaurus caecus (Cuvier, 1816 (1817)). Southern blind legless skink. Suricata, 1, 253.

Bauer, A.M. (2014b) Typhlosaurus lomiae Haacke, 1986. Lomi’s blind legless skink. Suricata, 1, 254.

Bauer, A.M. (2014c) Typhlosaurus meyeri Boettger, 1894. Meyer's blind legless skink. Suricata, 1, 254-255.

Bauer, A.M. (2014d) Typhlosaurus vermis Boulenger, 1887. Pink blind legless skink. Suricata, 1, 255.

Bauer, A.M. \& Branch, W.R. (2001) The herpetofauna of the Richtersveld National Park and the adjacent northern Richtesveld, northern Cape Province, Republic of South Africa. Herpetological Natural History, 8 (2), 111-160.

Bauer, A.M., Schneider, V., Lamb, T., Moler, P.E. \& Babb, R. (1999) New data on the South African acontine skink Typhlosaurus lomii Haacke 1986 (Squamata: Scincidae). African Journal of Herpetology, 48 (1-2), 21-25. https://doi.org/10.1080/21564574.1999.9651067

Bauer, A.M., Shea, G. \& Günther, R. (2003) An annotated catalogue of the types of scincid lizards (Reptilia, Squamata, Scin- 
cidae) in the collection of the Museum für Naturkunde der Humboldt-Universität zu Berlin (ZMB). Mitteilungen aus dem Museum für Naturkunde zu Berlin, Zoologische Reihe, 70 (2), 253-321.

https://doi.org/10.1002/mmnz.4850790204

Beddome, R.H. (1870) Descriptions of new reptiles from the Madras Presidency. Madras Monthly Journal of Medical Science, 2, 169-176.

Bell, T. (1833) Characters of two new genera of reptiles. Proceedings of the Zoological Society of London, 1, 98-99.

Bernstein, J.M., Jackman, T.R., Sadlier, R.A., Wang, Y.-Y. \& Bauer, A.M. (2021) A novel dataset to identify the endemic herpetofauna of the New Caledonia biodiversity hotspot with DNA barcodes. Pacific Conservation Biology. [published online] https://doi.org/10.1071/PC20055

Berriozabal-Islas, C., Ramírez-Bautista, A., Cruz-Elizalde, R. \& Hernández-Salinas, U. (2018) Modification of landscape as promoter of change in structure and taxonomic diversity of reptile's communities: an example in tropical landscape in the central region of Mexico. Nature Conservation, (28), 33-49. https://doi.org/10.3897/natureconservation.28.26186

Bibron, [G.] \& Bory de Saint-Vincent, [J.B.] (1833) Vertébrés a sang froid. Reptiles et poissons. In: Geoffroy Saint-Hilaire, I. \& Geoffroy Saint-Hilaire, É. (Eds.), Expédition Scientifique de Morée, Section des Sciences Physiques.Tome III.-1. ${ }^{\text {re Partie. }}$ Zoologie. Première Section.-Des animaux vertébrés. Mammiferes et Oiseaux. F.G. Levrault, Paris, pp. 57-80.

Blackburn, D.G. (1982) Evolutionary origins of viviparity in the Reptilia. I. Sauria. Amphibia-Reptilia, 3 (2), $185-205$. https://doi.org/10.1163/156853882X00419

Bloch, M.E. (1776) Beschreibung der Schleicheidexe, Lacerta serpens. Beschaftigungen der Berlinischen Gesellschaft naturforschender Freunde, 2, 28-34, pl. II.

Blyth, E. (1854) Report of Curator, Zoological Department, for September, 1854. Journal of the Asiatic Society of Bengal, 23 (7), 729-740.

Bodson, L. (2009) L'interprétation des noms grecs et latins d'animaux illustrée par le cas du zoonyme sēps-seps. Académie Royale de Belgique Mémoire de la Classe des Léttres, Collection in- $8^{\circ}$, Serie 3, 49 (2062), 1-368.

Boettger, O. (1893) Katalog der Reptilien-Sammlung im Museum der Senckenbergischen Naturforschenden Gesellschaft in Frankfurt am Main. I. Teil (Rhynchocephalen, Schildkröten, Krokodile, Eidechsen, Chamäleons). Gebrüder Knauer, Frankfurt am Main, $\mathrm{x}+140 \mathrm{pp}$.

Böhme, W., Schmitz, A. \& Ziegler, T. (2000) A review of the West African skink genus Cophoscincopus Mertens (Reptilia: Scincidae: Lygosominae): resurrection of C. simulans (Vaillant, 1884) and description of a new species. Revue Suisse de Zoologie, 107 (4), 777-791. https://doi.org/10.5962/bhl.part.80148

Bonnaterre, [P.J.] (1789) Tableau Encyclopédique et Méthodique des trois règnes de la nature. Erpétologie. Panckoucke, Paris, xxviii $+70+[1]$ pp., $7+6+12$ pls. https://doi.org/10.5962/bhl.title.11660

Bos, G., Burnett, C., Ryan, W.F. \& Taube, M. (2019) Maimonides'On Coitus. A new parallel Arabic-English Edition and Translation. The Medical Works of Moses Maimonides. Vol. 11. E.J. Brill, Leiden, x + 242 pp. https://doi.org/10.1163/9789004380080

Boucek, Z. (1974) On some Chalcididae and Pteromalidae (Hymenoptera), with descriptions of new genera and species from Africa and one species from Asia. Journal of the Entomological Society of Southern Africa, 37 (2), 327-343.

Boulenger, G.A. (1885) Synopsis of the families of existing Lacertilia. Annals and Magazine of Natural History, Series 5,14 (58), 117-122. https://doi.org/10.1080/00222938409459779

Boulenger, G.A. (1887) Catalogue of the Lizards in the British Museum (Natural History). Vol. III. Lacertidae, Gerrhosauridae, Scincidae, Anelytropidae, Dibamidae, Chamaeleontidae. Trustees of the British Museum (Natural History), London, xii + 575 pp., XL pls.

Bourquin, O. (2004) Reptiles (Reptilia) in KwaZulu-Natal: I-Diversity and distribution. Durban Museum Novitates, 29, 57103.

Bower, D.S., Brannelly, L.A., McDonald, C.A., Webb, R.J., Greenspan, S.E., Vickers, M., Gardner, M.G. \& Greenlees, M.J. (2019) A review of the role of parasites in the ecology of reptiles and amphibians. Austral Ecology, 44 (3), $433-448$. https://doi.org/10.1111/aec.12695

Bozkurt, E. \& Olgun, K. (2020) Taxonomic investigation of the genus Ablepharus (Sauria; Scincidae) with molecular and morphological methods in Anatolian populations. Turkish Journal of Zoology, 44, 134-145. https://doi.org/10.3906/zoo-1911-14

Branch, B. \& Kyle, S. (2005) Mehelya nyassae (Günther, 1888) black file snake: diet. African Herp News, 38, $24-25$.

Branch, W.R., Pinto, P.V., Baptista, N. \& Conradie, W. (2019) The reptiles of Angola: history, diversity, endemism and hotspots. In: Huntley, B.J., Russo, V., Lages, F. \& Ferrand, N. (Eds.), Biodiversity of Angola. Science \& Conservation: A Modern Synthesis. Springer Open, Cham, pp. 283-334. https://doi.org/10.1007/978-3-030-03083-4_13

Brandley, M.C., Schmitz, A. \& Reeder, T.W. (2005) Partitioned Bayesian analyses, partition choice, and the phylogenetic relationships of scincid lizards. Systematic Biology, 54 (3), 373-390.

https://doi.org/10.1080/10635150590946808 
Brandley, M.C., Huelsenbeck, J.P. \& Wiens, J.J. (2008) Rates and patterns in the evolution of snake-like body form in squamate reptiles: evidence for repeated re-evolution of lost digits and long-term persistence of intermediate body forms. Evolution, 62 (8), 2042-2064. https://doi.org/10.1111/j.1558-5646.2008.00430.x

Brandley, M.C., Ota, H., Hikida, T., Montes de Oca, A.N., Fería-Ortíz, M., Guo, X. \& Wang, Y. (2012) The phylogenetic systematics of blue-tailed skinks (Plestiodon) and the family Scincidae. Zoological Journal of the Linnean Society, 165 (1), $163-189$. https://doi.org/10.1111/j.1096-3642.2011.00801.x

Broadley, D.G. (1990) The herpetofaunas of the islands off the coast of south Moçambique. Arnoldia, Zimbabwe, 9 (35), 469-493.

Brongniart, A. (1800) Essai d'une classification naturelle des reptiles. Bulletin des Sciences, par la Société Philomatique, Paris, (36), 89-91, pl. VI.

Broom, R. (1898) On the lizards of the Chillagoe district, N. Queensland. Proceedings of the Linnean Society of New South Wales, 22 (3), 639-645. https://doi.org/10.5962/bhl.part.12735

Brown, R.M., McGuire, J.A., Ferner, J.W. \& Alcala, A.C. (1999) New species of diminutive scincid lizard (Squamata: Lygosominae: Sphenomorphus) from Luzon Island, Republic of the Philippines. Copeia, 1999 (2), 362-370. https://doi.org/10.2307/1447481

Brown, R.W. (1956) Composition of Scientific Words. A manual of methods and a lexicon of materials for the practice of logotechnics. Reprint. Smithsonian Books, Washington, D.C., 882 pp.

Brygoo, E.-R. (1980) Systématique des Lézards Scincidés de la région malgache. III. Les <<Acontias $>>$ de Madagascar: Pseudoacontias Barboza du Bocage, 1889, Paracontias Mocquard, 1894, Pseudacontias Hewitt, 1928, et Malacontias Greer, 1970. IV. Amphiglossus reticulatus (Kaudern, 1922) nov. comb., troisème espèce du genre; ses rapports avec Amphiglossus. Bulletin du Muséum nationale d'Histoire naturelle, Paris, Serie 4, 2 (Section A), (3), 905-918.

Brygoo E.-R. (1981) Systématique des Lézards Scincidés de la région malgache. IX. Nouvelles unités taxinomiques pour les Scelotes s.1. Bulletin du Muséum National d'Histoire Naturelle, Paris, Serie 4, 3 (Section A), (4), 1193-1204.

Bull, C.M., Gardner, M.G., Sih, A., Spiegel, O., Godfrey, S.S. \& Leu, S.T. (2017) Why is social behavior rare in reptiles? Lessons from sleepy lizards. Advances in the Study of Behavior, 49, 1-26. https://doi.org/10.1016/bs.asb.2017.02.001

Burton, E. (1836) A saurian reptile of the family Scincidae and of the genus Tiliqua, Gray. Proceedings of the Zoological Society of London, 1836, 62.

Caldwell, A.J., Cree, A. \& Hare, K.M. (2018) Parturient behaviour of a viviparous skink: evidence for maternal cannibalism when basking opportunity is low. New Zealand Journal of Zoology, 45 (4), 359-370. https://doi.org/10.1080/03014223.2018.1453845

Camp, C.L. (1923) Classification of the lizards. Bulletin of the American Museum of Natural History, 48 (11), $289-481$.

Čerňaňský, A. (2016) From lizard body form to serpentiform morphology: the atlas-axis complex in African cordyliformes and their relatives. Journal of Morphology, 277 (4), 512-536. https://doi.org/10.1002/jmor.20516

Čerňaňský, A. \& Syromyatnikova, E.V. (2021) The first pre-Quaternary fossil record of the clade Mabuyidae with a comment on the enclosure of the Meckelian canal in skinks. Papers in Palaeontology, 7 (1), 195-215. https://doi.org/10.1002/spp2.1279

Čerňaňský, A., Syromyatnikova, E.V., Kovalenko, E.S., Podurets, K.M. \& Kaloyan, A.A. (2020) The key to understanding the European Miocene Chalcides (Squamata, Scincidae) comes from Asia: the lizards of the East Siberian Tagay locality (Baikal Lake) in Russia. Anatomical Record, 303 (7), 1901-1934. https://doi.org/10.1002/ar.24289

Chapple, D.G. (2016a) Synthesising our current knowledge of New Zealand lizards. In: Chapple, D.G. (Ed.), New Zealand Lizards. Springer, Cham, pp. 1-11. https://doi.org/10.1007/978-3-319-41674-8_1

Chapple, D.G. (2016b) The future of NZ lizard research. In: Chapple, D.G. (Ed.), New Zealand Lizards. Springer, Cham, pp. 361-375. https://doi.org/10.1007/978-3-319-41674-8_14

Chapple, D.G. \& Hitchmough, R.A. (2016) Biogeography of New Zealand lizards. In: Chapple, D.G. (Ed.), New Zealand Lizards. Springer, Cham, pp. 109-131. https://doi.org/10.1007/978-3-319-41674-8_5

Chapple, D.G., Tingley, R., Mitchell, N.J., Macdonald, S.L., Keogh, J.S., Shea, G.M., Bowles, P., Cox, N.A. \& Woinarski, J.C.Z. (2019) The Action Plan for Australian Lizards and Snakes 2017. CSIRO Publishing, Clayton South, xvi + 663 pp. https://doi.org/10.1071/9781486309474

Chapple, D.G., Roll, U., Böhm, M., Aguilar, R., Amey, A.P., Austin, C.C., Baling, M., Barley, A.J., Bates, M.F., Bauer, A.M., Blackburn, D.G., Bowles, P., Brown, R.M., Chandramouli, S.R., Chirio, L., Cogger, H., Colli, G.R., Conradie, W., Couper, P.J., Cowan, M.A., Craig, M.D., Das, I., Datta-Roy, A., Dickman, C.R., Ellis, R.J., Fenner, A.L., Ford, S., Ganesh, S.R., Gardner, M.G., Geissler, P., Gillespie, G.R., Glaw, F., Greenlees, M.J., Griffith, O.W., Grismer, L.L., Haines, M.L., Harris, 
D.J., Hedges, S.B., Hitchmough, R.A., Hoskin, C.J., Hutchinson, M.N., Ineich, I., Janssen, J., Johnston, G.R., Karin, B.J., Keogh, J.S., Kraus, F., Lebreton, M., Lymberakis, P., Masroor, R., Mcdonald, P.J., Mecke, S., Melville, J., Melzer, S., Michael, D.R., Miralles, A., Mitchell, N.J., Nelson, N.J., Nguyen, T.Q., Nogueira, C.D., Ota, H., Pafilis, P., Pauwels, O.S.G., Perera, A., Pincheira-Donoso, D., Reed, R.N., Ribeiro-Júnior, M.A., Riley, J.L., Rocha, S., Rutherford, P.L., Sadlier, R.A., Shacham, B., Shea, G.M., Shine, R., Slavenko, A., Stow, A., Sumner, J., Tallowin, O.J.S., Teale, R., Torres-Carvajal, O., Trape, J.-F., Uetz, P., Ukuwela, K.D.B., Valentine, L., Van Dyke, J.U., Van Winkel, D., Vasconcelos, R., Vences, M., Wagner, P., Wapstra, E., While, G.M., Whiting, M.J., Whittington, C.M., Wilson, S., Ziegler, T., Tingley, R. \& Meiri, S. (2021) Conservation status of the world's skinks (Scincidae): taxonomic and geographic patterns in extinction risk. Biological Conservation, 257, 109101.

https://doi.org/10.1016/j.biocon.2021.109101

Chen, L., Lin, Y., Xiao, Q., Lin, Y., Du, Y., Lin, C., Ward-Fear, G., Hu, C., Qu, Y. \& Li, H. (2021) Characterization of the complete mitochondrial genome of the many-lined sun skink (Eutropis multifasciata) and comparison with other Scincomorpha species. Genomics, 113 (4), 2526-2536.

https://doi.org/10.1016/j.ygeno.2021.05.030

Chen, M., Liu, J., Chen, D. \& Guo, X. (2020) Complete mitochondrial genome of a blue-tailed skink Plestiodon capito (Reptilia, Squamata, Scincidae) and the comparison with other Scincidae lizards. Genetica, 148, 229-241. https://doi.org/10.1007/s10709-020-00107-1

Cogger, H.G., Cameron, E.E. \& Cogger, H.M. (1983) Zoological Catalogue of Australia. Vol. 1. Amphibia and Reptilia. Australian Government Publishing Service, Canberra, vi +313 pp.

Contreras-Lozano, J.A., Lazcano, D. \& Contreras-Balderas, A.J. (2019) Notes on Mexican herpetofauna 32: Ecological and altitudinal distribution of the herpetofauna in the Sierra de Bustamante, Nuevo León, Mexico. Bulletin of the Chicago Herpetological Society, 54 (4), 77-82.

Cope, E.D. (1864) On the characters of the higher groups of Reptilia Squamata - and especially of the Diploglossa. Proceedings of the Academy of Natural Sciences of Philadelphia, 16, 224-231.

Cope, E.D. (1868) Observations on reptiles of the Old World. II. Proceedings of the Academy of Natural Sciences of Philadelphia, 18, 316-328.

Cope, E.D. (1875) Check-list of North American Batrachia and Reptilia; with a systematic list of the higher groups, and an essay on geographical distribution. Based on the specimens contained in the U. S. National Museum. Bulletin of the United States National Museum, 1 (1), 1-104. https://doi.org/10.5962/bhl.title.11851

Cope, E.D. (1900) The crocodilians, lizards, and snakes of North America. Report of the U. S. National Museum, 1898, 1551270 , pls. $1-36$.

Cope, E.D. (1885) A contribution to the herpetology of Mexico. Proceedings of the American Philosophical Society, 22 (4), 379-404.

Couper, P.J., Worthington Wilmer, J., Roberts, L., Amey, A.P. \& Zug, G.R. (2005) Skinks currently assigned to Carlia aerata (Scincidae: Lygosominae) of north-eastern Queensland: a preliminary study of cryptic diversity and two new species. Australian Journal of Zoology, 53 (1), 35-49.

https://doi.org/10.1071/ZO04010

Crottini, A., Dordel, J., Köhler, J., Glaw, F., Schmitz, A. \& Vences, M. (2009) A multilocus phylogeny of Malagasy scincid lizards elucidates the relationships of the fossorial genera Androngo and Cryptoscincus. Molecular Phylogenetics and Evolution, 53 (1), 345-350.

https://doi.org/10.1016/j.ympev.2009.05.024

Cruz Elizalde, R., Padilla-García, U., Cruz Pérez, M.S. \& Navarro, C.T. (2016) Herpetofauna del Estado de Querétaro. In: Jones, R.W. \& Cárdenas V.S. (Eds.), Historia Natural de Querétaro. Universidad Autónoma de Querétaro, Querétaro, pp. 308-319.

Cruz-Elizalde, R., Ramírez-Bautista, A., Henández-Salinas, U., Berriozabal-Islas, C. \& Wilson, L.D. (2019) An updated checklist of the herpetofauna of Querétaro, Mexico: species richness, diversity, and conservation status. Zootaxa, 4638 (2), 273-290. https://doi.org/10.11646/zootaxa.4638.2.7

Cruz-Sáenz, D., Muñoz-Nolasco, F.J., Mata-Silva, V., Johnson, J.D., García-Padilla, E. \& Wilson, L.D. (2017a) The herpetofauna of Jalisco, Mexico: composition, distribution, and conservation status. Mesoamerican Herpetology, 4 (1), $23-118$.

Cruz-Sáenz, D., Muñoz-Nolasco, F.J., Téllez-López, J., Loeza Corichi, A. \& Romero-Rodríguez, H. (2017b) Anfibios y reptiles. In: La biodiversidad en Jalisco. Estudio de Estado. Vol. II. Comisión Nacional para el Conocimiento y Uso de la Biodiverdad, México, pp. 297-308.

Cuvier, [J.L.N.F.] (1816) [“1817”] Le Règne Animal distribué d'après son organization, pour server de base a l'histoire naturelle des animaux et d'introduction a l'anatomie comparée. Tome II., contenant les reptiles, les poissons, les mollusques et les annélides. Deterville, Paris, xviii $+532 \mathrm{pp}$.

Cuvier, [J.L.N.F.] (1829) Le Règne Animal distribué d'après son organisation, pour server de base a l'histoire naturelle des animaux et d'introduction a l'anatomie comparée. Tome II. Second Edition. Déterville et Crochard, Paris, xv $+406 \mathrm{pp}$.

Daniels, S.R., Heideman, N., Hendricks, M. \& Wilson, B. (2002) A molecular phylogeny for the South African limbless lizard taxa of the subfamily Acontinae (Sauria: Scincidae) with special emphasis on relationships within Acontias. Molecular 
Phylogenetics and Evolution, 24 (2), 315-323.

https://doi.org/10.1016/S1055-7903(02)00217-8

Daniels, S.R., Heideman, N.J.L., Hendricks, M.G.J., \& Crandall, K.A. (2006) Taxonomic subdivisions within the fossorial skink subfamily Acontinae (Squamata: Scincidae) reconsidered: a multilocus perspective. Zoologica Scripta, 35 (4), $353-362$. https://doi.org/10.1111/j.1463-6409.2006.00233.x

Darevsky, I.S. (1953) A new species of lidless skink from Armenian SSR (Ablepharus chernovi sp. nov. Reptilia, Sauria). Bulletin de la Société des naturalistes de Moscou, Série Biologique, 58 (2), 39-41 [in Russian].

Datta-Roy, A., Das, I., Bauer, A.M., Lyngdoh Tron, R.K. \& Karanth, P. (2013) Lizard wears shades. A spectacled Sphenomorphus (Squamata: Scincidae) from the sacred forests of Mawphlang, Meghalaya, north-east India. Zootaxa, 3701 (2), 257-276. https://doi.org/10.11646/zootaxa.3701.2.7

Daudin, F.M. (1802) Histoire naturelle, générale et particulière des Reptiles. Tome Quatrième. F. Dufart, Paris, 397 pp., pls. XLVI-LVIII.

De Vis, C.W. (1886) On a lizard and three species of Salarias etc. Proceedings of the Royal Society of Queensland, 2, 56-60. https://doi.org/10.5962/bhl.part.1909

De Vis, C.W. (1888) A contribution to the herpetology of Queensland. Proceedings of the Linnean Society of New South Wales, Series 2, 2 (4), 811-826. https://doi.org/10.5962/bhl.part.29213

De Vis, C.W. (1890) Reptiles from New Guinea. Proceedings of the Linnean Society of New South Wales, Series 2, 5 (3), 497-500. https://doi.org/10.5962/bhl.part.18650

de Witte, G.-F. \& Laurent, R.F. (1943) Contribution à la systématique des formes dégradées de la famille des Scincidae apparentées au genre Scelotes Fitzinger. Mémoires du Musée royal d'Histoire naturelle de Belgique, Series 2, $26,1-44$.

Denzer, W., Manthey, U., Wagner, P. \& Böhme, W. (2016) A critical review of Hoser's writings on Draconinae, Amphibolurinae, Laudakia and Uromastycinae (Squamata: Agamidae). Bonn zoological Bulletin, 64 (2), 117-138.

Desjardin, J. (1831) Sur trois espèces de lézard du genre scinque, qui habitent l'île Maurice (Ile-de-France). Annales des Sciences Naturelles, (1) 22, 292-299.

Dubois, A. (2008) A partial but radical solution to the problem of nomenclatural taxonomic inflation and synonymy load. Biological Journal of the Linnean Society, 93, 857-863. https://doi.org/10.1111/j.1095-8312.2007.00900.x

Dubois, A. \& Bour, R. (2010) The nomenclatural status of the nomina of amphibians and reptiles created by Garsault (1764), with a parsimonious solution to an old nomenclatural problem regarding the genus Bufo (Amphibia, Anura, comments on the taxonomy of this genus, and comments on some nomina created by Laurenti (1768). Zootaxa, 2447, 1-52. https://doi.org/10.11646/zootaxa.2447.1.1

Duméril, A. (1856) Note sur les reptiles du Gabon. Revue et Magasin de Zoologie Pure et Appliquée, (2) 8 (Septembre), 417-424, pls. 20-21.

Duméril, A.M.C. (1805) Zoologie Analytique, ou méthode naturelle de classification des animaux, rendue plus facile a l'aide de tableaux synoptiques. Allais, Paris, xxxii $+344 \mathrm{pp}$. https://doi.org/10.5962/bhl.title.44835

Duméril, A.M.C. \& Bibron, G. (1835) Erpétologie Générale ou Histoire Naturelle complète des Reptiles. Tome Second, contenant l'histoire de toutes les espèces de l'Ordre des Tortues ou Chéloniens, et les généralités de celui des Lézards ou Sauriens. Librairie Encyclopedique de Roret, Paris, ii + 680 pp., pls. 13-24. https://doi.org/10.5962/bhl.title.45973

Duméril, A.M.C. \& Bibron, G. (1839) Erpétologie Générale ou Histoire Naturelle complète des Reptiles. Tome Cinquième, contenant l'histoire de quatre-vingt-trois genres et de deux cent sept espèces de trois dernières Familles de l'Ordre des Sauriens, savoir: Les Lacertiens, Les Chalcidiens et les Scincoïdiens. Librairie Encyclopedique de Roret, Paris, viii +854 $+[1]$ pp., pls. 47-58.

Edeling, A.C.J. (1864) Recherches sur la faune erpétologique de Bornéo. Nederlandsch Tijdschrift voor de Dierkunde, 2 (4-6), 200-204.

Eftekharian, S.S., Jojati, V. \& Sharafi, S. (2017) The study of lizards and turtles fauna of Hezar Jarib Hunting Prohibited Area in Mazandaran Province. Journal of Animal Environment, 9 (2), 121-130. [in Farsi].

Elpatjevsky, V.S. (1901) The genus Ablepharus Fitz. in the collections of the Zoological Museum of Moscow University. Dnevnik Zoologicheskogo Otdeleniya obshchestva Lyubitelei Estestvoznania, Antropologii i Etnografii, 3 (2), 37-39. [in Russian]

Eremchenko, V.K. \& Szczerbak, N.N. (1980) On the generic membership of the ablepharine lizards (Reptilia, Sauria, Scincidae) fauna of the USSR. Vestnik Zoologii, 1980 (4), 10-15 [in Russian].

Erens, J., Miralles, A., Glaw, F., Chatrou, L.W. \& Vences, M. (2017) Extended molecular phylogenetics and revised systematics of Malagasy scincines lizards. Molecular Phylogenetics and Evolution, 107, 466-472. https://doi.org/10.1016/j.ympev.2016.12.008

Evenhuis, N.L. (2008) The "Mihi itch"—a brief history. Zootaxa, 1890 (1), 59-68. https://doi.org/10.11646/zootaxa.1890.1.3 
Fabricius, J.C. (1787) Mantissa Insectorum sistens species nuper detectas adiectis characteribus genericis, differentiis specificis, emendationibus, observationibus. Tome 1. Christ. Gottl. Proft., Hafniae, xvi +348 pp. https://doi.org/10.5962/bhl.title.11657

Feizi, H., Rastegar-Pouyani, N., Rastegar-Pouyani, N. \& Heidari, N. (2016) Systematics of the genera Eumeces Wiegmann, 1834 and Eurylepis Blyth 1854 (Sauria: Scincidae) in Iran: a review. Iranian Journal of Animal Systematics, 12 (2), $225-237$.

Fitzinger, L. (1824) Ueber den Ablepharus pannonicus, eine neue Eidechse aus Hungarn. Verhandlungen der Gesellschaft Naturforschender Freunde in Berlin, 1 (5), 297-302, pl. XIV.

Fitzinger, L.I. (1826) Neue Classification der Reptilien nach ihren natürlichen Verwandtschaften. Nebst einer verwandtschaftsTabel und einem verzeichnisse der Reptilien-Sammlung des K. K. Zoologischen Museum's zu Wien. J.G. Heubner, Wien, [vi] +66 pp., 1 pl. https://doi.org/10.5962/bhl.title.4683

Fitzinger, L. (1843) Systema Reptilium. Fasciculus Primus. Amblyglossae. Braumüller et Seidel, Vindobonae, $106+$ vi + [3] pp.

Fitzinger, L. (1847) Systema Reptilium. Isis von Oken, 30 (6), columns 471-475.

Fitzsimons, V.F. (1943) The lizards of South Africa. Transvaal Museum Memoir, 1, 1-528, pls. 1-24, 1 map.

Flower, S.S. (1933) Notes on the Recent reptiles and amphibians of Egypt, with a list of the species recorded from that kingdom. Proceedings of the Zoological Society of London, 1933 (3), 735-851. https://doi.org/10.1111/j.1096-3642.1933.tb01617.x

Forskål, P. (1775) Descriptiones animalium avium, amphibiorum, piscium, insectorum, vermium; quae in itinere Orientali observavit Petrus Forskål. Mölleri, Hauniae, $19+$ xxxiv +164 pp. https://doi.org/10.5962/bhl.title.2154

Foster, K.L., Garland, T., Schmitz, L. \& Higham, T.E. (2018) Skink ecomorphology: forelimb and hind limb lengths, but not static stability, correlate with habitat use and demonstrate multiple solutions. Biological Journal of the Linnean Society, 125 (4), 673-692. https://doi.org/10.1093/biolinnean/bly146

Fraga-Ramírez, Y., Suazo-Ortuño, I., Avila-Cabadilla, L.D., Alvarez-Añorve, M. \& Alvarado-Díaz, J. (2017) Multiscale analysis of factors influencing herpetofaunal assemblages in early successional stages of a tropical dry forest in western Mexico. Biological Conservation, 209, 196-210. https://doi.org/10.1016/j.biocon.2017.02.021

Frynta, D., Gunalen, D. \& Somerova, B. (2021) Genetic variation of blue-tongue skinks of the genus Tiliqua (Squamata: Scincidae) from New Guinea and Wallacea. Biologia, 76 (5), 1445-1455. https://doi.org/10.2478/s11756-020-00646-0

Fürbringer, M. (1900) Zur vergleichenden Anatomie des Brustschulterapparates und der Schultermuskeln. Jenaische Zeitschrift für Naturwissenschaft, 34 (1), 215-718. https://doi.org/10.5962/bhl.title.52377

Gadallah, N.S., Soliman, A.M. \& Al Dhafer, H.M. (2020) First record of the subfamily Epitraninae from Saudi Arabia (Hymenoptera, Chalcidoidea, Chalcididae), with the description of three new species. ZooKeys, 979, 35-86. https://doi.org/10.3897/zookeys.979.52059

Galdamez, J.R., Turcios-Casco, M.A. \& Salazar-Saavedra, M. (2019) Anfibios y Reptiles de Cuidad Blanca, La Mosquitia, Honduras. In: Larsen, T.H. (Ed.), A Rapid Biological Assessment of Cuidad del Jaguar, Ciudad Blanca, La Mosquitia, Honduras. RAP Bulletin of Biological Assessment, 72, 120-161.

Ganesh, S.R., Bhupathy, S., Karthik, P., Babu Rao, G. \& Babu, S. (2020) Catalogue of herpetological specimens from peninsular India at the Sálim Ali Centre for Ornithology \& Natural History (SACON), India. Journal of Threatened Taxa, 20 (9), $16123-16135$. https://doi.org/10.11609/jott.6036.12.9.16123-16135

García Grajales, J., Pineda-Ramos, B. \& Buenrostro-Silva, A. (2018) Diversidad herpetofaunística en un ambiente urbano de la ciudad de Puerto Escondido, Oaxaca, México. Revista Biodiversidad Neotropical, 8 (2), 108-118.

García Grajales, J., López-López, Y. \& Buenrostro Silva, A. (2019) Herpetofaunal diversity in a tropical dry forest on the Central Coast of Oaxaca, Mexico. Acta Universitaria, 29, e2406.

García-Padilla, E., DeSantis, D.L., Rocha, A., Johnson, J.D., Mata-Silva, V. \& Wilson, L.D. (2020) Conserving the Mesoamerican herpetofauna: The most critical case of the priority level one endemic species. Amphibian \& Reptile Conservation, 14 (2), 73-132. https://doi.org/10.15174/au.2019.2406

García-Padilla, E., Mata-Silva, V., Johnson, J.D. \& Wilson, L.D. (2021) Los anfibios y reptiles de "El Triunfo", Sierra Madre de Chiapas, México. Biodiversidad Mesoamericana, 2, 5-17.

Garsault, F.A.P. de (1764) Les Figures des plantes et animaux d'usage en médecine, décrits dans la Matière Médicale de Mr. Geoffroy Médecin. Desprez, Paris, [v] + 20 pp., pls. 644-729. https://doi.org/10.5962/bhl.title.49481

Gartrell, B. (2016) Diseases of New Zealand reptiles. In: Chapple, D.G. (Ed.), New Zealand Lizards. Springer, Cham, pp. 207-238. https://doi.org/10.1007/978-3-319-41674-8_8 
Gautam, B., Chalise, M.K., Thapa, K.B. \& Bhattarai, S. (2020) Distributional patterns of amphibians and reptiles in Ghandruk, Annapurna Conservation Area, Nepal. IRCF Reptiles \& Amphibians, 27 (1), 18-28.

https://doi.org/10.17161/randa.v27i1.14440

Gemel, R. \& Vergilov, V. (2020) Nomenclatural-taxonomic notes on the genus Ablepharus Fitzinger, 1824 (Squamata: Scincidae). Zootaxa, 4858 (3), 448-450.

https://doi.org/10.11646/zootaxa.4858.3.11

Geoffroy-Saint-Hilaire, I. (1827 [“1809”]) pp. 121-160. In: Geoffroy-Saint-Hilaire, [E.] Description des Reptiles qui se trouvent en Égypte. In: Description de l'Égypte, ou Recueil des Observations et des Recherches qui ont été faites en Égypte pendant l'Expédition de l'Armée Française. Histoire Naturelle. Tome Premier. Imprimerie Impériale, Paris, pp. 115-160. [The curious pagination and authorship of this publication reflects the chaotic writing of the natural history section of the Napoleonic Egyptian Expedition of 1798-1801, in which the two original naturalists, Étienne Geoffroy-Saint-Hilaire and Marie Jules-César Lelorgne de Savigny, made independent herpetological collections, and worked on them separately for over two decades before transferring responsibility to others in 1824-Étienne's son Isidore in the former case, due to his father's loss of interest in completing the text, and Victor Audouin in the latter case, due to neurological problems affecting de Savigny's sight and mental state, but working with plates that were engraved and printed many years previously (Gillispie 1989). As a consequence, while Étienne is the nominal author on the first page of his account, his section ended on page 120, with the remainder of the account, in which some of the skinks were described, written by his son at the request of the Minister for the Interior (as noted on pp. 120). Other skinks were described in de Savigny's section, written by Audouin. The dating of the various sections follows Sherborn (1897)]

Giles, J.A. (1840) A Lexicon of the Greek language, for the use of Colleges and Schools: containing, I. A Greek-English Lexicon, combining the advantages of an alphabetical and derivative arrangement; II. An English-Greek Lexicon, more copious than any that has yet appeared. To which is prefixed, A Concise Grammar of the Greek language. Second edition. Longman, Orme, Brown, Green, and Longmans, London, xxxvi + 939 pp.

Gilliams, J. (1818) Description of two new species of Linnaean Lacerta. Journal of the Academy of Natural Sciences of Philadelphia, 1 (2), 460-462.

Gillispie, C.C. (1989) Scientific aspects of the French Egyptian Expedition 1798-1801. Proceedings of the American Philosophical Society, 133 (4), 447-474.

Gmelin, J.F. (1789) Caroli a Linné, [Equitis aurati de stella polari, Archiatri Regii, Med. et Botan. Profess. Upsal. Acad. Paris. Upsal. Holm. Petropol. Berolin. Imper. Londin. Angl. Monsp. Tolos. Florent. Edinb. Bern. Soc.] Systema Naturae [per Regna Tria Naturae, secundum Classes, Ordines, Genera, Species, cum Characteribus, Differentiis, Synonymis, Locis]. Tom. I. Pars III. [Editio Decima Tertia, aucta, reformata.] Georg. Emanuel Beer, Lipsiae, pp. 1033-1516.

Göçmen, B., Kumlutaş, Y. \& Tosunoglu, M. (1996) A new subspecies, Ablepharus kitaibelii (Bibron \& Borry, 1833) budaki n. ssp. (Sauria: Scincidae) from the Turkish Republic of Northern Cyprus. Turkish Journal of Zoology, 20, 397-405.

Goicoechea, N., Frost, D.R., De la Rive, I., Pellegrino, K.C.M., Sites, J., Rodrigues, M.T. \& Padial, J.M. (2016) Molecular systematics of teioid lizards (Teioidea/Gymnophthalmoidea: Squamata) based on the analysis of 48 loci under tree-alignment and similarity-alignment. Cladistics, 32 (6), 624-671. https://doi.org/10.1111/cla.12150

Goldberg, S.R. (2006) Reproductive cycle of the striped legless skink, Typhlosaurus lineatus (Squamata: Scincidae) from southern Africa. Herpetological Bulletin, 98, 26-28.

Gonzalez-Sanchez, V.J., Johnson, J.D., García-Padilla, E., Mata-Silva, V., DeSantis, D.L. \& Wilson, L.D. (2017) The herpetofauna of the Mexican Yucatan Peninsula: composition, distribution, and conservation status. Mesoamerican Herpetology, 4 (2), 264-380.

Goodman, B.A. \& Isaac, J.L. (2008) Convergent body flattening in a clade of tropical rock-using lizards (Scincidae: Lygosominae). Biological Journal of the Linnean Society, 94 (2), 399-411. https://doi.org/10.1111/j.1095-8312.2008.00988.x

Graham, M.W.R.deV. (1994) Chalcis nigra Siebold, 1856 belongs to the genus Belaspidia Masi (Hym., Chalcididae). Entomologist's Monthly Magazine, 130 (1556-59), 19-20.

Grandidier, A. (1867) Liste des reptiles nouveaux découverts, en 1866, sur la côte sud-ouest de Madagascar. Revue et Magasin de Zoologie pure et appliquée et de Sériciculture comparée, Series 2, 19 (Juillet), 232-234.

Gray, J.E. (1825) A synopsis of the genera of Reptiles and Amphibia, with a description of some new species. Annals of Philosophy, Series 2, 10, 193-217.

Gray, J.E. (1827) Reptilia. In: King, P.P. Narrative of a survey of the intertropical and western coasts of Australia. Performed between the years 1818 and 1822. Vol. 2. John Murray, London, pp. 424-434, 1 pl.

Gray, J.E. (1831) A synopsis of the species of the Class Reptilia. In: Griffith, E. \& Pidgeon, E., The Animal Kingdom arranged in conformity with its organization, by the Baron Cuvier, member of the Institute of France, \&c. \&c. \&c. with additional descriptions of all the species hitherto named, and of many not before noticed. Vol. 9. The Class Reptilia arranged by the Baron Cuvier, with specific descriptions. Whittaker, Treacher, and Co., London, pp. 1-110.

Gray, J.E. (1835) Characters of a new genus of reptiles (Lialis) from New South Wales. Proceedings of the Zoological Society of London, 1834 (2), (23), 134-135.

Gray, J.E. (1838a) Catalogue of the slender-tongued saurians, with descriptions of many new genera and species. Annals and Magazine of Natural History, 1 (4), 274-283. 
https://doi.org/10.1080/00222933809512291

Gray, J.E. (1838b) Catalogue of the slender-tongued saurians, with descriptions of many new genera and species. [Continued from p. 283.]. Annals and Magazine of Natural History, 1 (5), 388-394.

https://doi.org/10.1080/00222933809512320

Gray, J.E. (1838c) Catalogue of the slender-tongued saurians, with descriptions of many new genera and species. [continued from vol. i. p. 394.]. Annals and Magazine of Natural History, 2 (10), 287-293.

https://doi.org/10.1080/00222933809496676

Gray, J.E. (1839) Catalogue of the slender-tongued saurians, with descriptions of many new genera and species. [Continued from p. 293.]. Annals and Magazine of Natural History, 2 (11), 331-337. https://doi.org/10.1080/00222933909512395

Gray, J.E. (1841a) A catalogue of the species of reptiles and amphibia hitherto described as inhabiting Australia, with a description of some new species from Western Australia, and some remarks on their geographical distribution. In: Grey, G., Journals of two expeditions of discovery in North-West and Western Australia, during the years 1837, 38, and 39, under the Authority of Her Majesty's Government. Describing many newly discovered, important, and fertile districts, with observations on the moral and physical condition of the aboriginal inhabitants, \&c. \&c. T. \& W. Boone, London, pp. 422-449, pls. $1-8$.

Gray, J.E. (1841b) Description of some new species and four new genera of reptiles from Western Australia, discovered by John Gould, Esq. Annals and Magazine of Natural History, 7 (42), 86-91. [publ. April 1841] https://doi.org/10.1080/03745484109442670

Gray, J.E. (1845) Catalogue of the specimens of lizards in the collection of the British Museum. Edward Newman, London, Xxviii $+289 \mathrm{pp}$.

Gray, J.E. (1856) New genus of fish-scaled lizards (Scissosarae) from New Guinea. Annals and Magazine of Natural History, Series 2, 18 (106), 345-346.

Greer, A.E. (1967) The generic relationships of the African scincid genus Eumecia. Breviora, 276, 1-9.

Greer, A.E. (1970a) A subfamilial classification of scincid lizards. Bulletin of the Museum of Comparative Zoology, 139 (3), 151-184.

Greer, A.E. (1970b) The relationships of the skinks referred to the genus Dasia. Breviora, 348, 1-30.

Greer, A.E. (1970c) The systematics and evolution of the sub-Saharan Africa, Seychelles, and Mauritius scincine scincid lizards. Bulletin of the Museum of Comparative Zoology, 140 (1), 1-23.

Greer, A.E. (1974) The generic relationships of the scincid lizard genus Leiolopisma and its relatives. Australian Journal of Zoology, Supplementary Series, 31, 1-67. https://doi.org/10.1071/AJZS031

Greer, A.E. (1976) On the evolution of the giant Cape Verde scincid lizard Macroscincus coctei. Journal of Natural History, 10 (6), 691-712. https://doi.org/10.1080/00222937600770551

Greer, A.E. (1977) The systematics and evolutionary relationships of the scincid lizard genus Lygosoma. Journal of Natural History, 11 (5), 515-540. https://doi.org/10.1080/00222937700770451

Greer, A.E. (1979) A phylogenetic subdivision of Australian skinks. Records of the Australian Museum, 32 (8), $339-371$. https://doi.org/10.3853/j.0067-1975.32.1979.459

Greer, A.E. (1986) Lygosomine (Scincidae) monophyly: a third, corroborating character and a reply to critics. Journal of Herpetology, 20 (1), 123-126. https://doi.org/10.2307/1564144

Greer, A.E. (1989) The Biology and Evolution of Australian Lizards. Surrey Beatty \& Sons, Chipping Norton, xvi +264 pp.

Greer, A.E. (2001) Distribution of maximum snout-vent length among species of scincid lizards. Journal of Herpetology, 35 (3), 383-395. https://doi.org/10.2307/1565956

Greer, A.E. (2002) The loss of the external ear opening in scincid lizards. Journal of Herpetology, 36 (4), 544-555. https://doi.org/10.1670/0022-1511(2002)036[0544:TLOTEE]2.0.CO;2

Greer, A.E. \& Chong, J. (2007) Number of maxillary teeth in scincid lizards: lineage characteristics and ecological implications. Journal of Herpetology, 41 (1), 94-101. https://doi.org/10.1670/0022-1511(2007)41[94:NOMTIS]2.0.CO;2

Greer, A.E. \& Shea, G. (2000) A phylogenetically important lygosomine skink resurrected from taxonomic obscurity: Lygosoma unilineatum de Rooij, 1915. Journal of Herpetology, 34 (1), 85-91. https://doi.org/10.2307/1565243

Griffith, H., Ngo, A. \& Murphy, R.W. (2000) A cladistic evaluation of the cosmopolitan genus Eumeces Wiegmann (Reptilia, Squamata, Scincidae). Russian Journal of Herpetology, 7 (1), 1-16.

Grismer, L.L., Wood, P.L., Syafiq, M.F., Badli-Sham, B.H., Rizal, S.A., Ahmad, A.B. \& Quah, E.S.H. (2016) On the taxonomy and phylogeny of the skinks Lipinia sekayuensis Grismer, Ismail, Awang, Riza, \& Ahmad and Lipinia surda Boulenger from Peninsular Malaysia. Zootaxa, 4147 (1), 59-66. https://doi.org/10.11646/zootaxa.4147.1.3 
Gronovius, L.T. (1756) Amphibiorum Animalium Historia Zoologica exhibens Amphibiorum, qui in Museo Laurentii Theodori Gronovii, J.U. D. adservantur, Descriptiones corine systematico. In: Gronovius, L.T. Musei Ichthyologici Tomus Secundus sistens Piscium indigenorum \& nonnullorum exoticorum, quorum maxima pars in Museo Laurentii Theodori Gronovii, J.U.D. Theodorum Haak, Lugduni Batavorum, pp. 47-86.

Gronovius, L.T. (1763) Zoophylacii Gronoviani Fasciculus Primus exhibens Animalia Quadrupeda, Amphibia atque Pisces. Theodorum Haak et Socium et Samuelem et Johannem Luchtmans, Lugduni Batavorum, 136 pp.

Guenée, A. (1841) Essai sur la classification des Noctuélides (Suite et fin.). Annales de la Société entomologique de France, $10,217-250$.

Gupta, A. \& Poorani, J. (2008) New records of Chalcidoidea (Hymenoptera) from southern India. Biosystematica, 1 (2), $21-$ 24.

Haacke, W.D. (1986) Description of a new species of Typhlosaurus Wiegmann, 1834 (Reptilia: Scincidae) from the west coast of southern Africa, with new records of related species. Annals of the Transvaal Museum, 34 (9), 227-235.

Habu, A. (1978) On three Brachymeria species of Japan (Hymenoptera, Chalcididae). Entomological Review of Japan, 32 (1-2), 113-124.

Halliwell, B., Uller, T., Chapple, D.G., Gardner, M.G., Wapstra, E. \& While, G.M. (2017a) Habitat saturation promotes delayed dispersal in a social reptile. Behavioural Ecology, 28 (2), 515-522. https://doi.org/10.1093/beheco/arw181

Halliwell, B., Uller, T., Holland, B.R. \& While, G.M. (2017b) Live bearing promotes the evolution of sociality in reptiles. Nature Communications, 8, 2030. https://doi.org/10.1038/s41467-017-02220-w

Halliwell, B., Uller, T., Wapstra, E. \& While, G.M. (2017c) Resource distribution mediates social and mating behavour in a family living lizard. Behavioural Ecology, 28 (1), 145-153. https://doi.org/10.1093/beheco/arw134

Halstead, J.A. (1986) On the distribution of Ceratosmicra meteori and C. paya (Hymenoptera: Chalcididae) in North America. Entomological News, 97 (3), 99-100.

Halstead, J.A. (1990) Redescription of males, biological notes, and identification of American Acanthochalcis (Hymenoptera: Chalcididae). Entomological News, 101 (2), 75-80.

Halstead, J.A. (2000) A new species of Hockeria Walker from Mexico (Hymenoptera: Chalcididae). Pan-Pacific Entomologist, $76(1), 52-54$.

Hardwicke, [T.] \& Gray, J.E. (1827) A synopsis of the species of saurian reptiles, collected in India by Major-General Hardwicke. Zoological Journal, 3 (10), 213-229.

Hardy, G.S. (1979) The karyotypes of two scincid lizards, and their bearing on relationships in genus Leiolopisma and its relatives (Scincidae: Lygosominae). New Zealand Journal of Zoology, 6 (4), 609-612. https://doi.org/10.1080/03014223.1979.10428403

Hare, K.M. Schumann, N., Hoskins, A.J., Daugherty, C.H., Towns, D.R. \& Chapple, D.G. (2020) Predictors of translocation success of captive-reared lizards: implications for their captive management. Animal Conservation, 23 (3), 320-329. https://doi.org/10.1111/acv.12544

Harlan, R. (1825) Description of a new species of Scincus. Journal of the Academy of Natural Sciences of Philadelphia, 4 (2), 286-288.

Harrison, B.C., Sajdak, R.A., Henderson, R.W. \& Powell, R. (2019) Additional evidence of arboreality of the Greater Windward Skink, Copeoglossum aurae (Reptilia: Squamata: Mabuyidae) on Carriacou (Grenada Grenadines). IRCF Reptiles \& Amphibians, 26 (1), 47-48. https://doi.org/10.17161/randa.v26i1.14333

Harvey, M.B., Aguayo, R. \& Miralles, A. (2008) Redescription and biogeography of Mabuya cochabambae Dunn with comments on Bolivian congeners (Lacertilia: Scincidae). Zootaxa, 1828 (1), 43-56.

https://doi.org/10.11646/zootaxa.1828.1.4

Hasselquist, F. (1751) Lacerta scincus. Acta Societatis Regiae Scientiarum Upsaliensis, 1744-1750, 30-33.

Hasselquist, F. (1757) Iter Palaestinum eller Resa til Heliga Landet, forrattad ifrån Ar 1749 til 1752, med Beskrifningar, Ron, Anmarkningar, ofver de Markvardigaste Naturalier, pa Hennes Kongl. Maj:ts befallning, utgifven af Carl Linnaeus. Lars Salvii, Stockholm, [xiv] $+619+[1] \mathrm{pp}$. https://doi.org/10.5962/bhl.title. 112563

Hedges, S.B. (2014) The high-level classification of skinks (Reptilia, Squamata, Scincomorpha). Zootaxa, 3765 (4), $317-338$. https://doi.org/10.11646/zootaxa.3765.4.2

Hedges, S.B. \& Conn, C.E. (2012) A new skink fauna from Caribbean islands (Squamata, Mabuyidae, Mabuyinae). Zootaxa, 3288 (1), 1-244.

https://doi.org/10.11646/zootaxa.3288.1.1

Hedges, S.B., Powell, R., Henderson, R.W., Hanson, S. \& Murphy, J.C. (2019a) Definition of the Caribbean Islands biogeographic region, with checklist and recommendations for standardized common names of amphibians and reptiles. Caribbean Herpetology, 67, 1-53.

https://doi.org/10.31611/ch.67

Hedges, S.B., Lorvelec, O., Barre, N., Vidal, N. \& Pavis, C. (2019b) On the taxonomic recognition of skinks from the Guade- 
loupe Archipelago (Squamata, Mabuyidae, Mabuya). Caribbean Herpetology, 64, 1-7.

https://doi.org/10.31611/ch.64

Heideman, N.J.L., Daniels, S.R., Mashinini, P.L., Mokone, M.E., Thibedi, M.L., Hendricks, M.G.J., Wilson, B.A. \& Douglas, R.M. (2008) Sexual dimorphism in the African legless skink subfamily Acontiinae (Reptilia: Scincidae). African Zoology, 43 (2), 192-201. https://doi.org/10.1080/15627020.2008.11657236

Hitchmough, R.A., Patterson, G.B. \& Chapple, D.G. (2016) Putting a name to diversity: taxonomy of the New Zealand lizard fauna. In: Chapple, D.G. (Ed.), New Zealand Lizards. Springer, Cham, pp. 87-108. https://doi.org/10.1007/978-3-319-41674-8_4

Hofman, E.P., Fiss, C.J., Johnson, K.E., Rodríguez, F., Larkin, J.T., Larkin, J.L., Chavarría-Duriaux, L., Duriaux, G. \& Townsend, J.H. (2016) Inventario preliminar de herpetofauna de la Reserva Silvestre Privada El Jaguar (Jinotega, Nicaragua). Revista Nicaraguense de Bidiversidad, 7, 1-18.

Honda, M., Ota, H., Kobayashi, M., Nabhitabhata, J., Yong, H.-S. \& Hikida, T. (1999a) Evolution of Asian and African lygosomine skinks of the Mabuya group (Reptilia: Scincidae). Zoological Science, 16, 535-549. https://doi.org/10.2108/zsj.16.535

Honda, M., Ota, H., Kobayashi, M. \& Hikida, T. (1999b) Phylogenetic relationships of Australian skinks of the Mabuya group (Reptilia: Scincidae) inferred from mitochondrial DNA sequences. Genes and Genetic Systems, 74, 135-139. https://doi.org/10.1266/ggs.74.135

Honda, M., Ota, H., Kobayashi, M., Nabhitabhata, J., Yong, H.-S. \& Hikida, T. (2000) Phylogenetic relationships, character evolution and biogeography of the subfamily Lygosominae (Reptilia: Scincidae) inferred from mitochondrial DNA sequences. Molecular Phylogenetics and Evolution, 15 (3), 452-461. https://doi.org/10.1006/mpev.1999.0767

Honda, M., Ota, H., Kohler, G., Ineich, I., Chirio, L., Chen, S.-L. \& Hikida, T. (2003) Phylogeny of the lizard subfamily Lygosominae (Reptilia: Scincidae), with special reference to the origin of the New World taxa. Genes and Genetic Systems, 78, $71-80$. https://doi.org/10.1266/ggs.78.71

Horton, D.R. (1972) Evolution in the genus Egernia (Lacertilia: Scincidae). Journal of Herpetology, 6 (2), 101-109. https://doi.org/10.2307/1562800

Hoser, R.T. (2015a) A revision of the genus level taxonomy of the Acontinae and Scincinae, with the creation of new genera, subgenera, tribes and subtribes. Australasian Journal of Herpetology, 28, 1-64.

Hoser, R.T. (2015b) A revision of the genus level taxonomy of the Acontinae and Scincinae, with the creation of new genera, subgenera, tribes and subtribes. Australasian Journal of Herpetology, 29, 65-128.

Husain, T. \& Agarwal, M.M. (1982) Taxonomic studies on Haltichellinae of India (Hymenoptera: Chalcididae) Pt. 1. Haltichellini. Oriental Insects, 16 (3), 313-336. https://doi.org/10.1080/00305316.1982.10434319

Hutchinson, M.N., Donnellan, S.C., Baverstock, P.R., Krieg, M., Simms, S. \& Burgin, S. (1990) Immunological relationships and generic revision of the Australian lizards assigned to the genus Leiolopisma (Scincidae, Lygosominae). Australian Journal of Zoology, 38 (5), 535-554. https://doi.org/10.1071/ZO9900535

Ingram, G.J. \& Ehmann, H. (1981) A new species of scincid lizard of the genus Leiolopisma (Scincidae: Lygosominae) from south-eastern Queensland and north-eastern New South Wales. Memoirs of the Queensland Museum, 20 (2), 307-310.

International Trust for Zoological Nomenclature (1985) International Code of Zoological Nomenclature Third Edition adopted by the XX General Assembly of the International Union of Biological Sciences. International Trust for Zoological Nomenclature, London, $\mathrm{xx}+338 \mathrm{pp}$.

Jablonski, D. (2016) Tail bifurcation in a Desert Lidless Skink (Ablepharus deserti) from Kyrgyzstan. IRCF Reptiles \& Amphibians, 23 (3), 171-172. https://doi.org/10.17161/randa.v23i3.14126

Jacobsen, N.H.G. (1987) A new subspecies of Typhlosaurus lineatus Boulenger 1887 (Reptilia: Scincidae) from Venda, southern Africa. South African Journal of Zoology, 22 (4), 318-320. https://doi.org/10.1080/02541858.1987.11448064

Jennings, M.T. (2006) An aggregation of Haltichella rufipes Olivier 1790 (Hym., Chalcididae) in Kent. Entomologist's Monthly Magazine, 142 (1703-1705), 102.

Johnson, J.D., Mata-Silva, V. \& Wilson, L.D. (2015a) A conservation reassessment of the Central American herpetofauna based on the EVS measure. Amphibian \& Reptiles Conservation, 9 (2), e100.

Johnson, J.D., Mata-Silva, V., García Padilla, E. \& Wilson, L.D. (2015b) The herpetofauna of Chiapas, Mexico: composition, distribution, and conservation. Mesoamerican Herpetology, 2 (3), 272-329.

Johnson, J.D., Wilson, L.D., Mata-Silva, V., García-Padilla, E. \& DeSantis, D.L. (2017) The endemic herpetofauna of Mexico: organisms of global significance in severe peril. Mesoamerican Herpetology, 4 (3), 544-620.

Joseph, K.J., Narendran, T.C. \& Joy, P.J. (1972) New species of Oriental Brachymerla Westwood (Hymenoptera: Chalcididae) in the collections of Rijksmuseum van Natuurlijke Historie, Leiden. Oriental Insects, 6 (1), 45-53.

https://doi.org/10.1080/00305316.1972.10434052 
Kaiser, H., Crother, B.I., Kelly, C.M.R., Luiselli, L., O’Shea, M., Ota, H., Passos, P., Schleip, W. \& Wüster, W. (2013) Best practices: in the $21^{\text {st }}$ century, taxonomic decisions in herpetology are acceptable only when supported by a body of evidence and published via peer-review. Herpetological Review, 44 (1), 8-23.

Karin, B.J., Metallinou, M., Weinell, J.L., Jackman, T.R. \& Bauer, A.M. (2016) Resolving the higher-order phylogenetic relationships of the circumtropical Mabuya group (Squamata: Scincidae): an out-of-Asia diversification. Molecular Phylogenetics and Evolution, 102, 220-232.

https://doi.org/10.1016/j.ympev.2016.05.033

Kauffeld, C.F. (1937) The proper name for the African lizard, Scincus officinalis. Herpetologica, 1 (3), 97.

Kazemi, M.-H. \& Lotfalizadeh, H. (2014) Hockeria magna Boucek (Hymenoptera: Chalcididae): New record to Iranian chalcidid fauna. North-Western Journal of Zoology, 10 (1), 183-186.

Kemp, M.E. \& Hadly, E.A. (2015) Extinction biases in Quaternary Caribbean lizards. Global Ecology and Biogeography, 24 (11), 1281-1289. https://doi.org/10.1111/geb.12366

Kerguelen, V. \& Carde, R.T. (1998) Flight toward a learned odor and factors inducing landing of female Brachymeria intermedia (Hymenoptera: Chalcididae), a parasitoid of the gypsy moth, Lymantria dispar (Lepidoptera: Lymantriidae). Journal of Insect Behavior, 11 (2), 221-234. https://doi.org/10.1023/A:1021095907381

Kollar, V. (ed.) (1847) Bildliche Naturgeschichte aller drei Reiche, mit vorzüglicher Berücksichtigung der für das allgemeine Leben wichtigeren Naturprodukte. Zweiter Band. G. Adolf Hartleben, Pest, 519 pp., LXXXVIII pls.

Krysko, K.L., Enge, K.M. \& Moler, P.E. (2019) Amphibians and reptiles of Florida. University Press of Florida, Gainesville, Florida, $728 \mathrm{pp}$.

Kuhl, H. (1820) Beiträge zur Zoologie und vergleichenden Anatomie. Hermannschen Buchhandlung, Frankfurt am Main, 212 pp., XI pls.

Lacepede [Lacépède, B.G.E.] (1788) Histoire Naturelle des Quadrupèdes ovipares et des Serpens. Tome I. Hotel de Thou, Paris, $651 \mathrm{pp}$. https://doi.org/10.5962/bhl.title.5036

Lacépède, [B.G.E.] (1804) Mémoire sur plusieurs animaux de la Nouvelle-Hollande dont la description n'a pas encore été publiée. Annales du Muséum National d'Histoire Naturelle, Paris, 4, 184-211, pls. 55-58.

Lamb, T., Biswas, S. \& Bauer, A.M. (2010) A phylogenetic reassessment of African fossorial skinks in the subfamily Acontinae (Squamata: Scincidae): evidence for parallelism and polyphyly. Zootaxa, 2657 (1), 33-46. https://doi.org/10.11646/zootaxa.2657.1.3

Lang, M. \& Böhme, W. (1990) Description and phylogenetic position of a new species of Isopachys from central Thailand and southern Burma/Myanmar (Squamata, Scincidae). Bulletin de l'Institut Royal des Sciences Naturelles de Belgique, Biologie, 60, 231-240.

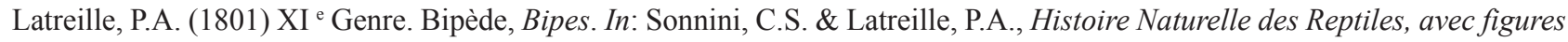
dessinées d'après nature. Tome II. Première Partie. Quadrupèdes et Bipèdes Ovipares. Deterville, Paris, pp. 90-96.

Latreille, [P.A.] (1817) Le Règne Animal, distribué d'apres son organisation, pour servir de base a l'histoire naturelle des animaux et d'introduction a l'anatomie comparée. Tome 3, Les Crustacés, les Arachnides et les Insectes. Deterville, Paris, $\mathrm{xxix}+653 \mathrm{pp}$.

Laurenti, J.N. (1768) Specimen medicum, exhibens synopsin reptilium emendatam cum experimentis circa venena et antidota reptilium austriacorum. Joan. Thom. Nob. De Trattnern, Viennae, 214 pp., V pls. https://doi.org/10.5962/bhl.title.5108

Lazcano, D., Reyes, M.N., García-Padilla, E., Johnson, J.D., Mata-Silva, V., DeSantis, D.L. \& Wilson, L.D. (2019) The herpetofauna of Coahuila, Mexico: composition, distribution, and conservation status. Amphibian \& Reptile Conservation, 13 (2), 31-94.

Leenders, T. (2019) Reptiles of Costa Rica. A Field Guide. Cornell University Press, Ithaca, New York, 640 pp. https://doi.org/10.7591/9781501739545

Lesson, R.-P. (1830) Reptiles. In: Histoire naturelle, Zoologie. Atlas. In: Duperrey, L.I. Voyage autour du monde, Exécuté par Ordre du Roi, sur la Corvette de Sa Majesté, La Coquille, pendant les années 1822, 1823, 1824 et 1825. Arthus Bertrand, Paris, pl. 4.

Lettinck, M. \& Hare, K.M. (2016) Sampling techniques for New Zealand lizards. In: Chapple, D.G. (Ed.), New Zealand Lizards. Springer, Cham, pp. 269-291. https://doi.org/10.1007/978-3-319-41674-8_10

Leviton, A.E., Anderson, S.C., Adler, K. \& Minton, S.A. (1992) Handbook to Middle East Amphibians and Reptiles. Society for the Study of Amphibians and Reptiles, Oxford, vi $+252 \mathrm{pp}$.

Lewis, C.T. \& Short, C. (1891) A New Latin Dictionary founded on the translation of Freund's Latin=German Lexicon edited by E. A. Andrews, LL.D. Harper \& Brothers, New York, xiv +2019 pp.

Lichtenstein, H. (1823) Verzeichniss der Doubletten des zoologischen Museums der Königl. Universität zu Berlin nebst Beschreibung vieler bisher unbekannter Arten von Säugethieren, Vögeln, Amphibien und Fischen. T. Trautwein, Berlin, $\mathrm{x}+118$ pp., 1 pl.

Liddell, H.G. \& Scott, R. (1882) A Greek-English Lexicon. Eighth Edition. American Book Company, New York, xvi +1774 
pp.

Linnaeus, C. (1758) Systema Naturae per regna tria naturae, secundum Classes, Ordines, Genera, Species, cum characteribus, differentiis, synonymis, locis. Editio Decima, Reformata. Tomus I. Laurentii Salvii, Holmiae, $823+$ [1] pp. https://doi.org/10.5962/bhl.title.542

Linnaeus, C. (1766) Systema Naturae per regna tria naturae, secundum Classes, Ordines, Genera, Species, cum characteribus, differentiis, synonymis, locis. Editio Duodecima, Reformata. Tomus I. Laurentii Salvii, Holmiae, 531 pp. https://doi.org/10.5962/bhl.title.68927

Lloyd, R. (2015) Twenty-five years buried: rediscovery of the Bungle Bungle Robust Slider, Lerista bunglebungle (Lacertilia; Sphenomorphidae). Western Australian Naturalist, 30 (1), 36-42.

Lorvelec, O., Barré, N. \& Bauer, A.M. (2017) The status of the introduced Mourning Gecko (Lepidodactylus lugubris) in Guadeloupe (French Antilles) and the high probability of introduction of other species with the same pattern of distribution. Caribbean Herpetology, 57, 1-6. https://doi.org/10.31611/ch.57

Loveridge, A. (1920) Notes on East African lizards collected in 1915-1919, with description of a new genus and species of skink and new subspecies of gecko. Proceedings of the Zoological Society of London, 1920 (1-2), 131-167. https://doi.org/10.1111/j.1469-7998.1920.tb07639.x

Loveridge, A. (1936) African reptiles and amphibians in Field Museum of Natural History. Zoological Series Field Museum of Natural History, 22 (1), 1-111. https://doi.org/10.5962/bhl.title.3069

Loveridge, A. (1957) Check list of the reptiles and amphibians of East Africa (Uganda; Kenya; Tanganyika; Zanzibar). Bulletin of the Museum of Comparative Zoology, 117 (2), 151-362.

Macey, J.R., Schulte, J.A., Strasburg, J.L., Brisson, J.A., Larson, A., Ananjeva, N.B., Wang, Y., Parham, J.F. \& Papenfuss, T.J. (2006) Assembly of the eastern North American herpetofauna: new evidence from lizards and frogs. Biology Letters, 2 , 388-392. https://doi.org/10.1098/rsbl.2006.0473

Macleay, W. (1877) The lizards of the "Chevert" Expedition. Proceedings of the Linnean Society of New South Wales, 2 (1), 60-69. https://doi.org/10.5962/bhl.part.12420

Manhas, A., Raina, R. \& Wanganeo, A. (2018) Reptilian diversity and distribution in the Doda District of Jammu and Kashmir, India. IRCF Reptiles and Amphibians, 25 (3), 164-169. https://doi.org/10.17161/randa.v25i3.14288

Mangetus, J.J. (1687) Pharmacopoea Schödero-Hoffmanniana Illustrata et Aucta, qua composita quaeque celebriora, hinc Mineralia, Vegetabilia \& Animalia Chimico-Medicè describuntur, atque insuper Principia Physica Hermetoco-Hippocraticae candidè exhibentur. Opus Selectissimorum Quorumque tum Pharmacologirum \& Chimiatrorum, Tum Celeberrimoru inter Receniores Practicorum, Tum Operum Varioru Miscellaneorum, nec non curiosiorum rerum naturalisum scriptorium Nobilissimus Medicamentis atque Descriptionibus abundè ditatum. Samuelis de Tournes, Geneve, [1] + 800 + [96] pp., 7 pls.

Marchiori, C.H., Pereira, L.A. \& Filho, O.M.S. (2002) Brachymeria podagrica (Fabricius) (Hymenoptera: Chalcididae) as a parasitoid of Chrysomya albiceps (Wiedemann) (Diptera: Calliphoridae): first report in Brazil. Arquivo Brasileiro de Medicina Veterinaria e Zootecnia, 54 (5), 555-557. https://doi.org/10.1590/S0102-09352002000500019

Mata-Silva, V., Johnson, J.D., Wilson, L.D. \& García-Padilla, E. (2015) The herpetofauna of Oaxaca, Mexico: composition, physiographic distribution, and conservation status. Mesoamerican Herpetology, 2 (1), 6-62.

Mata-Silva, V., DeSantis, D.L., Garcia-Padilla, E., Johnson, J.D. \& Wilson, L.D. (2019) The endemic herpetofauna of Central America: a casualty of anthropocentrism. Mesoamerican Herpetology, 13 (1), e168.

Mausfeld, P., Schmitz, A., Böhme, W., Misof, B., Vrcibradic, D. \& Rocha, C.F.D. (2002) Phylogenetic affinities of Mabuya atlantica Schmidt, 1945, endemic to the Atlantic Ocean archipelago of Fernando de Noronha (Brazil): necessity of partitioning the genus Mabuya Fitzinger, 1826 (Scincidae: Lygosominae). Zoologischer Anzeiger, 241 (3), 281-293. https://doi.org/10.1078/0044-5231-00081

McAllister, C.T., Duszynski, D.W., Fisher, R.N. \& Austin, C.C. (2014) A new species of Eimeria Schneider, 1875 (Apicomplexa: Eimeriidae) from the Solomon ground skink, Sphenomorphus solomonis (Boulenger) (Sauria: Scincidae) from Papua New Guinea. Systematic Parasitology, 87, 83-86. https://doi.org/10.1007/s11230-013-9455-2

McCranie, J.R., Castañeda, F.E., Estrada, N., Ferrufino, L., Germer, D., Matamoros, W. \& Sagastume-Espinoza, K.O. (2019) Biodiversity in Honduras: the environment, flora, bats, medium and large-sized mammals, birds, freshwater fishes, and the amphibians and reptiles. In: Pullaiah, T. (Ed.), Global Biodiversity. Vol. 4. Selected Countries in the Americas and Australia. Apple Academic Press, Boca Raton, Florida, pp. 213-284. https://doi.org/10.1201/9780429433634-7

McCranie, J.R., Matthews, A.J. \& Hedges, S.B. (2020) A morphological and molecular revision of lizards of the genus Marisora Hedges \& Conn (Squamata: Mabuyidae) from central America and Mexico, with descriptions of four new species. Zootaxa, 4763 (3), 301-353. 
https://doi.org/10.11646/zootaxa.4763.3.1

Mead, J.I., Moscato, D., Wang, Y., Jin, C. \& Yan, Y. (2014) Pleistocene lizards (Squamata, Reptilia) from the karst caves in Chongzuo, Guangxi, southern China. Quaternary International, 354, 94-99.

https://doi.org/10.1016/j.quaint.2014.03.047

Medina, M.F., Bauer, A.M., Branch, W.R., Schmitz, A., Conradie, W., Nagy, Z.T., Hibbitts, T.J., Ernst R., Portik, D.M., Nielsen, S.V., Colston, T.J., Kusamba, C., Behangana, M., Rödel, M.-O. \& Greenbaum, E. (2016) Molecular phylogeny of Panaspis and Afroablepharus skinks (Squamata: Scincidae) in the savannas of sub-Saharan Africa. Molecular Phylogenetics \& Evolution, 100, 409-423. https://doi.org/10.1016/j.ympev.2016.04.026

Medina-Fitoria, A., Toval, N., Maes, J.M., Gutiérrez, A., Hernández, B., Vega, G., Debrix, A., Salazar, M., López, A., Urcuyo, S.J. \& Urcuyo, J. (2018) Diversidad biológica de la cuenca baja del Río Grande de Matagalpa en el Caribe de Nicaragua. Revista Nicaraguense de Biodiversidad, 38, 1-190.

Melville, R. (1982) Opinions 1207 Leptotyphlops and Ramphotyphlops Fitzinger, 1843 (Reptilia, Serpentes): conserved. Bulletin of Zoological Nomenclature, 39 (2), 106-108.

Merrem, B. (1820) Versuch eines Systems der Amphibien/Tentamen Systematis Amphibiorum. J.C. Kreiger, Marburg, xv + 191 pp., 1 pl. [duplicating facing pages of German and Latin with identical pagination, up to p. 188] https://doi.org/10.5962/bhl.title.5037

Mertens, R. (1952) Über den Glattechechsen-Namen Ablepharus pannonicus. Zoologischer Anzeiger, 149 (1/2), $48-50$.

Mesue, J. (1550) In Antidotarium Ioannis Filii Mesuae, Censura. Cum declaration simplicium Medicinarium, \& solutione multorum dubiorum ac difficilium terminorum. Ad haec, Receptarium quam castigatissimum cum suo repertorio, in calce apposuimus. Ioannem Frellonium, Lugduni, $\mathrm{xxx}+622 \mathrm{pp}$.

Metallinou, M., Weinell, J.L., Karin, B.R., Conradie, W., Wagner, P., Schmitz, A., Jackman, T.R. \& Bauer, A.M. (2016) A single origin of extreme matrotrophy in African mabuyine skinks. Biology Letters, 12 (8), 20160430. https://doi.org/10.1098/rsbl.2016.0430

Meyer, A.B. (1874) Mittheilung über die von ihm auf Neu-Guinea und den Inseln Jobi, Mysore und Mafoor im Jahre 1873 gesammelten Amphibien. Monatsberichte der königlich Preussischen Akademie der Wissenschaften zu Berlin, 1874 (Februar), $128-140$.

Michels, J.P. \& Bauer, A.M. (2004) Some corrections to the scientific names of amphibians and reptiles. Bonner Zoologische Beitraege, 52 (1-2), 83-94.

Miralles, A., Hipsley, C.A., Erens, J., Gehara, M., Rakotoarison, A., Glaw, F., Müller, J. \& Vences, M. (2015) Distinct patterns of desynchronized limb regression in Malagasy scincine lizards (Squamata, Scincidae). PLoS One, 10 (6), e0126074. https://doi.org/10.1371/journal.pone.0126074

Miranda, J.P., Costa, J.C.L. \& Rocha, C.F.D. (2012) Reptiles from Lençóis Marenhenses National Park, Maranhão, northeastern Brazil. Zookeys, 246, 51-68. https://doi.org/10.3897/zookeys.246.2593

Mittleman, M.B. (1952) A generic synopsis of the lizards of the subfamily Lygosominae. Smithsonian Miscellaneous Collections, 117 (17), 1-35.

Moch, J.G. \& Senter, P. (2011) Vestigial structures in the appendicular skeletons of eight African skink species (Squamata, Scincidae). Journal of Zoology, 285 (4), 274-280. https://doi.org/10.1111/j.1469-7998.2011.00839.x

Mocquard, F. (1894) Reptiles nouveaux ou insuffisamment connus de Madagascar. Compte Rendu sommaire des Séances de la Société philomathique de Paris, 17, 3-10.

Murthy, T.N.S. (1981) Reptiles of the Silent Valley and New Amarambalam area, Kerala. The Snake, 13 (1), 42-52.

Narendran, T.C. (1988) A new genus of Chalcididae (Hymenoptera: Chalcidoidea) from the collections of United States National Museum of Natural History, Washington, D.C. Journal of the Bombay Natural History Society, 85 (1), $158-160$.

Norval, G. \& Gardner, M.G. (2020) The natural history of the sleepy lizard, Tiliqua rugosa (Gray, 1825) - Insight from chance observations and long-term research on a common Australian skink species. Austral Ecology, 45 (4), 410-417. https://doi.org/10.1111/aec.12715

Norval, G., Clayton, J., Sharrad, R. D. \& Gardner, M.G. (2018) Notes on the stomach contents of a juvenile sleepy lizard, Tiliqua rugosa (Gray 1825), killed by an eastern brown snake, Pseudonaja textilis (Duméril, Bibron, and Duméril 1854) in South Australia. IRCF Reptiles \& Amphibians, 25 (3), 200-203. https://doi.org/10.17161/randa.v25i3.14304

Norval, G., Bursey, C.R., Goldberg, S.R., Sharrad, R.D., Ross, K.E. \& Gardner, M.G. (2021) New host and locality records for gastrointestinal helminths of five reptile species from the Mid North region of South Australia. Transactions of the Royal Society of South Australia, 145 (1), 45-59. https://doi.org/10.1080/03721426.2021.1913539

Novelli, I.A., de Oliveira, P.R., Castañon, M.C.M.N., Silva, P.C. \& de Sousa, B.M. (2018) Morphological and histological characterization of the sexual segment of the kidney in Notomabuya frenata (Cope, 1862) and Aspronema dorsivittatum (Cope, 1862) (Squamata, Mabuyidae). Anais da Academia Brasileira de Ciências, 90 (2 Supplement 1), 2267-2278. https://doi.org/10.1590/0001-3765201820170871

Nussbaum, R.A. \& Raxworthy, C.J. (1995) Review of the scincine genus Pseudoacontias Barboza du Bocage (Reptilia: Squa- 
mata: Scincidae) of Madagascar. Herpetologica, 51 (1), 91-99.

Ochsenheimer, F. (1816) Die Schmetterlinge von Europa. Vierter Band. Gerhard Fleischer dem Jungern, Leipzig, x + 225 + [1] pp.

Oken, [L.] (1816) Okens Lehrbuch der Naturgeschichte. Dritter Theil Zoologie. Zweite Abtheilung. Fleischthiere. August Schmid und Comp., Jena, xvi +1270 pp.

Oppel, M. (1811) Die Ordnungen, Familien und Gattungen der Reptilien als Prodrome einer Naturgeschichte derselben. Joseph Lindauer, München, xii $+86+[1] \mathrm{pp}$. https://doi.org/10.5962/bhl.title.4911

Ortiz, M.A., Boretto, J.M. \& Ibargüengoytía, N.R. (2019) Reproductive biology of a viviparous lizard (Mabuya dorsivittata) from the subtropical Wet Chaco of Argentina: geographical variations in response to local environmental pressures. Anais da Academia Brasileira de Ciências, 91 (1), e20170817. https://doi.org/10.1590/0001-3765201920170817

O'Shea, M. (2021) Lizards of the World: A Guide to Every Family. Ivy Press, London, 239 pp. https://doi.org/10.1515/9780691211831

Ouboter, P.E. (1986) A revision of the genus Scincella (Reptilia: Sauria: Scincidae) of Asia, with some notes on its evolution. Zoologisches Verhandelingen, 229, 1-66.

Pallas, P.S. (1775) Lacerta apoda descripta. Novi Commentarii Academiae Scientiarum Imperialis Petropolitanae, 19, 435454.

Paluh, D.J. \& Bauer, A.M. (2017) Comparative skull anatomy of terrestrial and crevice-dwelling Trachylepis skinks (Squamata: Scincidae) with a survey of resources in scincid cranial osteology. PLoS ONE, 12 (9), e0184414. https://doi.org/10.1371/journal.pone.0184414

Patterson, G.B. \& Hitchmough, R.A. (2021) A new alpine skink species (Scincidae: Eugongylinae: Oligosoma) from Kahurangi National Park, New Zealand. Zootaxa, 4920 (4), 495-508. https://doi.org/10.11646/zootaxa.4920.4.2

Pawar, P.R., Rokade, A.G., Supnekar, S.P., Meshram, L.N. \& Pawar, N.B. (2020) Preliminary data on species diversity of amphibians and reptiles (excluding snakes) from Panvel, Navi Mumbai, India. Asian Journal of Advances in Research, 4 (2), $18-30$.

Pearson, S.K., Johnston, G.R., Bull, C.M., Fenner, A.L. \& Gardner, M.G. (2020) Fine-scale genetic structuring in a group-living lizard, the gidgee skink (Egernia stokesii). Austral Ecology, 45 (4), 435-443.

https://doi.org/10.1111/aec.12862

Pereira, A.G. \& Schrago, C.G. (2017) Arrival and diversification of mabuyine skinks (Squamata: Scincidae) in the Neotropics based on a fossil-calibrated timetree. PeerJ, 5, e3194. https://doi.org/10.7717/peerj.3194

Perret, J.-L. (1975) La différenciation dans le genre Panaspis Cope (Reptilia, Scincidae). Bulletin de la Société Neuchâteloise des Sciences Naturelles, 98, 5-16.

Perret, J.-L. \& Wuest, J. (1982) La structure fine des écailles de quelques Lygosominae africains (Lacertilia, Scincidae), révélée par le microscope électronique à balayage. Revue Suisse de Zoologie, 89, 269-280. https://doi.org/10.5962/bhl.part.82442

Peters, W. (1864) Über die Eidechsenfamilie der Scincoiden, insbesondere über die Schneider'schen, Wiegmann'schen und neue Arten des zoologischen Museums. Monatsberichte der königlich Akademie der Wissenschaften zu Berlin, 1864 (Januar), 44-58.

Peters, W. (1866) Über neue Amphibien (Amphibolurus, Lygosoma, Cyclodus, Masticophis, Crotaphopeltis) und Fische (Diagramma, Hapalogenys) des Kgl. Zoologischen Museums. Monatsberichte der königlich Akademie der Wissenschaften zu Berlin, 1866 (Februar), 86-96.

Peters, W. (1874) Uber neue Saurier (Spaeriodactylus, Anolis, Phrynosoma, Tropidolepisma, Lygosoma, Ophioscincus aus Centralamerica, Mexico und Australien. Monatsberichte der königlich Akademie der Wissenschaften zu Berlin, 1873 (November), 738-747.

Peters, W. \& Doria, G. (1878) Catalogo dei rettili e dei batraci raccolti da O. Beccari, L. M. D’Albertis e A. A. Bruijn, nella sotto-regione Austro-Malese. Annali del Museo Civico di Storia Naturale di Genova, 13, 323-450, pls. 1-7.

Potter, J. (1702) Archaeologia Graeca, sive Veterum Graecorum, praecipue vero Atheniensium, ritus civiles, religiosi, militares et domestici. Petrus Vender, Lugduni Batavorum, [6] pp. + $788+[26]$ columns.

Poulakakis, N., Lymberakis, P., Tsigenopoulos, C.S., Magoulas, A. \& Mylonas, M. (2005) Phylogenetic relationships and evolutionary history of snake-eyed skink Ablepharus kitaibelii (Sauria: Scincidae). Molecular Phylogenetics and Evolution, 34 (2), 245-256. https://doi.org/10.1016/j.ympev.2004.10.006

Poyarkov, N.A., Geissler, P., Gorin, V.A., Dunayev, E.A., Hartmann, T. \& Suwannapoom, C. (2019) Counting stripes: revision of the Lipinia vittigera complex (Reptilia, Squamata, Scincidae), with description of two new species from Indochina. Zoological Research, 40 (5), 358-393. https://doi.org/10.24272/j.issn.2095-8137.2019.052

Prakash, G., Sagadai, M. \& Rasappan, K. (2016) New records of chalcidid (Hymenoptera: Chalcididae) pupal parasitoids from India. Biodiversity Data Journal, 4, e6900. 
https://doi.org/10.3897/BDJ.4.e6900

Prasopsin, S., Thongnetr, W., Tanomtong, A., Chuaynkern, Y. \& Patawang, I. (2017) Cytogenetics of the skinks (Reptilia, Scincidae) from Thailand: III: the first karyological study of Sphenomorphus maculatus and Jarujinia bipedalis. Caryologica, $70(3), 216-221$. https://doi.org/10.1080/00087114.2017.1324716

[Prüss, J.] (1507) In disem Buch ist der Herbary, oder krüterbuch: genant der gart der gesuntheit: mit merern figuren und registern. [Johannes Prüss], Strassburg, [406] pp.

Pyron, R.A., Burbrink, F.T. \& Wiens, J.J. (2013) A phylogeny and revised classification of Squamata, including 4161 species of lizards and snakes. BMC Evolutionary Biology, 13, 93. https://doi.org/10.1186/1471-2148-13-93

Qian, Y., Li, X. \& He, J. (1992) Four new species of Haltichellini (Hymenoptera: Chalcididae) from China. Entomotaxonomia, $14(2), 122-128$.

Quoy, [J.R.] \& Gaimard, [J.P.] (1824) Description d'une nouvelle espèce de Tortue et de trois espèces nouvelles de Scinques. Bulletin des Sciences Naturelles et de Géologie, 1, 90-91.

Rabosky, D.L., Doughty, P. \& Huang, H. (2017) Lizards in pinstripes: morphological and genomic evidence for two new species of scincid lizards within Ctenotus piankai Storr and C. duricola Storr (Reptilia: Scincidae) in the Australian arid zone. Zootaxa, 4303 (1), 1-26. https://doi.org/10.11646/zootaxa.4303.1.1

Raddi, G. (1823) Continuazione della descrizione dei Rettili Brasiliani. Memorie di Matematica e di Fisica delle Società Italiana delle Scienze Residente in Modena, 19, 58-73.

Rafinesque, C.S. (1815) Analyse de la Nature ou Tableau de l'Univers et des Corps organisés. The author, Palerme, 224 pp. https://doi.org/10.5962/bhl.title.106607

Rahnama, M.E. \& Jojati, V. (2018) The study of lizards fauna in Esas Protected Area in Mazandaran Province. Journal of Animal Environment, 10 (4), 203-210. [in Farsi]

Ramírez-Bautista, A. \& Cruz-Elizalde, R. (2013) Reptile community structure in two fragments of cloud forest of the Sierra Madre Oriental, Mexico. North-Western Journal of Zoology, 9 (2), 410-417.

Ramírez-Bautista, A., Hernández-Salinas, U., Cruz-Elizalde, R., Berriozabal-Islas, C., Lara-Tufiño, D., Mayer-Goyenechea, I.R. \& Castillo-Cerón, J.M. (2014) Los anfibios y reptiles de Hidalgo, México: diversidad, biogeografía y conservacion. Sociedad Herpetologica Mexicana, 387 pp.

Ramirez-Bautista, A., Hernandez-Salinas, U., Cruz-Elizalde, R., Berriozabal-Islas, C., Moreno-Lara, I., DeSantis, D.L., Johnson, J.D., Garcia-Padilla, E., Mata-Silva, V. \& Wilson, L.D. (2020) The herpetofauna of Hidalgo, Mexico: composition, distribution, and conservation status. Amphibian \& Reptile Conservation, 14 (1), 63-118.

Rasplus, J.-Y. \& Delvare, G. (1996) Révision des Tanycoryphus (Hymenoptera: Chalcididae) ouest-Paléarctiques et description de deux nouvelles espèces européennes. Annales de la Société Entomologique de France, 32 (2), 223-232.

Raven, C.E. (1950) John Ray Naturalist His Life and Works. Second Edition. Cambridge University Press, Cambridge, xx + 506 pp.

Rawlinson, P.A. (1974) Revision of the endemic southeastern Australian lizard genus Pseudemoia (Scincidae: Lygosominae). Memoirs of the National Museum of Victoria, 35, 87-96, pl. 5. https://doi.org/10.24199/j.mmv.1974.35.03

Ray, J. (1693) Synopsis Methodica Animalium Quadrupedum et Serpentini Generis. Vulgarium Notas Characteristicas, Rariorum Descriptiones integras exhibens: cum Historiis \& Observationibus Anatomicis perquam curiosis. Praemittuntur nonnulla De Animalium in genere, Sensu, Generatione, Divisione, \&c. S. Smith \& B. Walford, London, [xiv] + 336 + [8] pp. https://doi.org/10.5962/bhl.title.41459

Razzetti, E. \& Msuya, C.A. (2002) Field Guide to the Amphibians and Reptiles of Arusha National Park (Tanzania). Tanzania National Parks, 84 pp.

Reeder, T.W. (2003) A phylogeny of the Australian Sphenomorphus group (Scincidae: Squamata) and the phylogenetic placement of the crocodile skinks (Tribolonotus): Bayesian approaches to assessing congruence and obtaining confidence in maximum likelihood inferred relationships. Molecular Phylogenetics and Evolution, 27 (3), 384-397. https://doi.org/10.1016/S1055-7903(02)00448-7

Reyes, M.N., Lazcano, D., García-Padilla, E., Mata-Silva, V., Johnson, J.D. \& Wilson, L.D. (2016) The herpetofauna of Nuevo Leon, Mexico: composition, distribution, and conservation. Mesoamerican Herpetology, 3 (3), 558-638.

Ridley, J.C.H., Schlesinger, C.A. \& Bull, C.M. (2020) Location of long-term communal burrows of a threatened arid-zone lizard in relation to soil and vegetation. Austral Ecology, 45 (4), 444-453. https://doi.org/10.1111/aec.12656

Rieppel, O. (1981) The skull and the jaw adductor musculature in some burrowing scincomorph lizards of the genera Acontias, Typhlosaurus and Feylinia. Journal of Zoology, 195 (4), 493-528. https://doi.org/10.1111/j.1469-7998.1981.tb03480.x

Rieppel, O. (1982) The phylogenetic relationships of the genus Acontophiops Sternfeld (Sauria: Scincidae), with a note on mosaic evolution. Annals of the Transvaal Museum, 33 (12), 241-257.

Riley, J.L., Baxter-Gilbert, J.H. \& Whiting, M.J. (2021) Social and spatial patterns of two Afromontane crag lizards (Pseudocordylus spp.) in the Maloti-Drakensberg Mountains, South Africa. Austral Ecology, 46 (5), 847-859. 
https://doi:10.1111/aec.13030.

Rondelet, G. (1555) Uniuersae aquatilium Historiae pars altera, cum veris ipsorum Imaginibus. Matthiam Bonhomme, Lugduni, $[\mathrm{x}]+242+[9] \mathrm{pp}$.

Roux, C. (1976) On the dating of the first edition of Cuvier's Règne Animal. Journal of the Society for the Bibliography of Natural History, 8 (1), 31. https://doi.org/10.3366/jsbnh.1976.8.1.31

Roy, C.S. \& Farooqi, S.I. (1984) Taxonomy of Indian Haltichellinae (Chalcididae: Hymenoptera) at National Pusa Collection, IARI, New Delhi. Memoirs of the Entomological Society of India, 10, 1-59.

Sadlier, R.A., Bauer, A.M., Shea, G.M. \& Smith, S.A. (2015) Taxonomic resolution to the problem of polyphyly in the New Caledonian scincid lizard genus Lioscincus (Squamata: Scincidae). Records of the Australian Museum, 67 (7), $207-224$. https://doi.org/10.3853/j.2201-4349.67.2015.1649

Safaei-Mahroo, B., Ghaffari, H., Fahimi, H., Broomand, S., Yazdanian, M., Najafi Majd, E., Hosseinian Yousefkhani, S.S., Rezazadeh, E., Hosseinzadeh, M.S., Nasrabadi, R., Rajabizadeh, M., Mashayekhi, M., Motesharei, A., Naderi, A. \& Kazemi, S.M. (2015) The herpetofauna of Iran: checklist of taxonomy, distribution and conservation status. Asian Herpetological Research, 6 (4), 257-290.

Sakata, S. \& Hikida, T. (2003) A fossorial lizard with forelimbs only: description of a new genus and species of Malagasy skink (Reptilia: Squamata: Scincidae). Current Herpetology, 22, 9-15. https://doi.org/10.5358/hsj.22.9

Sánchez-Martínez, P.M., Ramírez-Pinilla, M.P., Meneses-Pelayo, E. \& Sales Nunes, P.M. (2019) Hemipenial morphology of nine South American species of Mabuya (Scincidae: Lygosominae) with comments on the morphology of the family. Anatomical Record, 303 (11), 2917-2930.

https://doi.org/10.1002/ar.24329

Say, [T.] (1822) Genus Scincus, Daud. In: James, E. Account of an expedition from Pittsburgh to the Rocky Mountains, performed in the years 1819 and '20, by order of the Hon. J. C. Calhoun, Sec'y of War: under the command of Major Stephen H. Long. Vol. 2. H. C. Carey \& I. Lea, Philadelphia, Pennsylvania, pp. 324-325.

Schlegel, H. (1834) Monographie van het geslacht Zonurus. Tijdschrift voor Natuurlijke Geschiedenis en Physiologie, 1, 203221.

Schlegel, H. (1837) 1te Decade. In: Schlegel, H. Abbildungen neuer oder unvollständig bekannter Amphibien, nach der Natur oder dem Leben entworfen. Arnz \& Comp., Düsseldorf, pp. 1-31, pls. I-X. https://doi.org/10.5962/bhl.title.95393

Schmidt, A.D. (2002) The herpetofauna of the Langjan Nature Reserve (Limpopo Province, Republic of South Africa) (Amphibia, Reptilia). Herpetozoa, 15 (3-4), 121-135.

Schmidt, K.P. (1945) A new name for a Brazilian Mabuya. Copeia, 1945 (1), 45. https://doi.org/10.2307/1438176

Schmidt, W. (2014) Update on reptile taxonomy post-publication of the Atlas and Red List of the Reptiles of South Africa, Lesotho and Swaziland. African Herp News, 61, 8-10.

Schmitz, A., Brandley, M.C., Mausfeld, P., Vences, M., Glaw, F., Nussbaum, R.A. \& Reeder, T.W. (2005) Opening the black box: phylogenetics and morphological evolution of the Malagasy fossorial lizards of the subfamily "Scincinae". Molecular Phylogenetics and Evolution, 34, 118-133. https://doi.org/10.1016/j.ympev.2004.08.016

Schneider, J.G. (1801) Historiae Amphibiorum naturalis et literariae. Fasciculus Secundus continens Crocodilos, Scincos, Chamaesauras, Boas, Pseudoboas, Elapes, Angues, Amphibaenas et Caecilias. Fried. Frommann, Jenae, vi + 364 pp., 2 pls.

Schneider, V. \& Bauer, A.M. (2009) Typhlosaurus jappi Broadley, 1968, a valid species of acontine skink. African Journal of Herpetology, 58 (1), 56-58. https://doi.org/10.1080/21564574.2009.9635582

Seba, A. (1735) Locupletissimi rerum naturalium thesauri accurata descriptio, et iconibus artificiosissimis expressio, per universam physices historiam. Opus, cui, in hoc rerum genere, nullum par exstitit. J. Wetstenium, Gul. Smith, \& JanssonioWaesbergios, Amsteladeami, [xxx] +154 pp., cxiv pls. https://doi.org/10.5962/bhl.title.62680

Sengupta, D., Borah, C.G. \& Phukon, J. (2019) Assessment of the reptilian fauna in the Brahmaputra Plains of two districts in Assam, India. IRCF Reptiles \& Amphibians, 26 (1), 65-67. https://doi.org/10.17161/randa.v26i1.14346

Shaw, G. (1802) General Zoology, or Systematic Natural History. Vol. III. Part I. Amphibia. G. Kearsley, London, viii + 312 pp.

Shea, G.M. (2019) Current status of the genera Karma and Magmellia Wells, 2009 (Scincidae: Lygosominae: Sphenomorphini), with a morphological character to distinguish the two genera. Memoirs of the Queensland Museum-Nature, 61, 187-191. https://doi.org/10.17082/j.2204-1478.61.2019.2018-03

Sherborn, C.D. (1897) On the dates of the Natural History portion of Savigny's 'Description de l'Egypte.' Proceedings of the Zoological Society of London, 1897 (1), 285-287. 
Shine, R., Branch, W.R., Harlow, P.S. \& Webb, J.K. (1998) Reproductive biology and food habits of Horned Adders, Bitis caudalis (Viperidae), from southern Africa. Copeia, 1998 (2), 391-401. https://doi.org/10.2307/1447433

Sidren, J. (1750) D. D. Dissertatio de Materia Medica in Regno Animali, quam, consent. amplissima Facultate Medica in Regia Academia Upsaliensi, Praeside, viro experientissimo, Dn. Doct. Carolo Linnaeo, S: ae R:ae M:tis Archiatro, Med. et Botan. Profess. Reg. et Ord. Acad. Imper. Monspel. Stockholm. Upsal. et Berolinens. Socio, Pro Gradu Doctoris Publico Examini Medeste Subjicit Alumnus Kåhreanus. W. Gothus, Upsaliae, 20 pp.

Silva, A.F.C., Bras, S.X., Serra, R.T.A., Andrade, G.V. \& Costa, J.C.L. (2021) Geographic distribution extension of Manciola guaporicola (Dunn, 1935) (Squamata: Mabuyidae) for the State of Maranhão, Northeastern Brazil. Herpetology Notes, 14, 197-199.

Simon of Genoa (1514) Simonis Ianuensis opusculum cui nomen clavis sanationis simplicia medicinalia Latina greca at arabica ordine Alphabetico mirifice elucidans recognitum ac mendis purgatum et quotationibus Plinii maxime: ac aliorum in marginibus ornatum et quam diligentius ac correctius id fieri potuit impressum. Gregorium de Gregoriis, Ventiis, 128 pp.

Simser, D.H. \& Coppel, H.C. (1980) Female-produced sex pheromone in Brachymeria lasus and B. intermedia [Hym.: Chalcididae]. Entomophaga, 25 (4), 373-380. https://doi.org/10.1007/BF02374700

Skinner, A., Hugall, A.F. \& Hutchinson, M.N. (2011) Lygosomine phylogeny and the origins of Australian scincid lizards. Journal of Biogeography, 38 (6), 1044-1058. https://doi.org/10.1111/j.1365-2699.2010.02471.x

Skourtanioti, E., Kapli, P., Ilgaz, Ç., Kumlutaş, Y., Avci, A., Ahmadzadeh, F., Crnobrnja-Isailović, J., Gherghel, I., Lymberakis, P. \& Poulakakis, N. (2016) A reinvestigation of phylogeny and divergence times of the Ablepharus kitaibelii species complex (Sauria, Scincidae) based on mtDNA and nuDNA genes. Molecular Phylogenetics and Evolution, 103, $199-214$. https://doi.org/10.1016/j.ympev.2016.07.005

Smith, S.A., Sadlier, R.A., Bauer, A.M., Austin, C.C. \& Jackman, T. (2007) Molecular phylogeny of the scincid lizards of New Caledonia and adjacent areas: evidence for a single origin of the endemic skinks of Tasmantis. Molecular Phylogenetics and Evolution, 43 (3), 1151-1166. https://doi.org/10.1016/j.ympev.2007.02.007

Solís, J.M., Wilson, L.D. \& Townsend, J.H. (2014) An updated list of the amphibians and reptiles of Honduras, with comments on their nomenclature. Mesoamerican Herpetology, 1 (1), 123-144.

Sonnini, C.S. \& Latreille, P.A. (1801) Histoire Naturelle des Reptiles, avec figures dessinées d'après nature. Tome II. Première Partie. Quadrupèdes et Bipèdes Ovipares. Deterville, Paris, 332 pp. https://doi.org/10.5962/bhl.title.4688

Spawls, S. \& Rotich, D. (1997) An annotated checklist of the lizards of Kenya. Journal of East African Natural History, 86, 61-83. https://doi.org/10.2982/0012-8317(1997)86[61:AACOTL]2.0.CO;2

Speybroeck, J., Beukema, W., Dufresnes, C., Fritz, U., Jablonski, D., Lymberakis, P., Martínez-Solano, I., Razzetti, E., Vamberer, M., Vences, M., Vörös, J., \& Crochet, P.-A. (2020) Species list of the European herpetofauna-2020 update by the Taxonomic Committee of the Societas Europaea Herpetologica. Amphibia-Reptilia, 41 (2), 139-189. https://doi.org/10.1163/15685381-bja10010

Spix, J.B. von (1825) Animalia nova sive species novae lacertarum, quas in itinere per Brasiliam annis MDCCCXVIIMDCCCXX jussu et auspiciis Maximiliani Josephi I. Bavariae Regis suscepto collegit et descripsit Dr. J. B. de Spix. Franc. Seraph. Hübschmanni, Monachii, [iv] + 26 pp., XXVIII pls. https://doi.org/10.5962/bhl.title.5117

Stampe, K., Larsen, O.N. \& Godfrey, S.S. (2020) Ecto- and endoparasites of the King's skink (Egernia kingii) on Penguin Island. Parasitology, 147 (10), 1094-1099. https://doi.org/10.1017/S0031182020000839

Steffan, J.R. (1976) Les Euchalcidia Masi du bassin méditerranéen [Hym. Chalcididae]. Bulletin de la Société Entomologique de France, 81 (1-2), 52-63.

Steindachner, F. (1899) Bericht über eine von Herrn Professor Simony während der südarabischen Expedition in Sokotra entdeckte neue Sepsina-Art, die zugleich einer besonderen Subgattung (Hakaria) angehört. Anzeiger der Kaiserlichen Akademie der Wissenschaften, Wien, Mathematisch-naturwissenschaftliche Klasse, 36 (12), 161-162.

Stejneger, L. (1926) Chinese amphibians and reptiles in the United States National Museum. Proceedings of the United States National Museum, 66 (2562), 1-115.

https://doi.org/10.5479/si.00963801.66-2562.1

Stejneger, L. (1936) Types of the amphibian and reptilian genera proposed by Laurenti in 1768. Copeia, 1936 (3), $133-141$. https://doi.org/10.2307/1435820

Stewart, J.R. \& Ecay, T.W. (2010) Patterns of maternal provision and embryonic mobilization of calcium in oviparous and viviparous squamate reptiles. Herpetological Conservation and Biology, 5 (2), 341-359.

Stewart, J.R. \& Thompson, M.B. (1994) Placental structure of the Australian lizard, Niveoscincus metallicus (Squamata: Scincidae). Journal of Morphology, 220 (3), 223-236.

https://doi.org/10.1002/jmor.1052200302 
Stewart, J.R. \& Thompson, M.B. (1996) Evolution of reptilian placentation: development of extraembryonic membranes of the Australian scincid lizards, Bassiana duperreyi (oviparous) and Pseudemoia entrecasteauxii (viviparous). Journal of Morphology, 227 (3), 349-370. https://doi.org/10.1002/(SICI)1097-4687(199603)227:3<349::AID-JMOR6>3.0.CO;2-0

Stewart, J.R. \& Thompson, M.B. (2003) Evolutionary transformations of the fetal membranes of viviparous reptiles: a case study of two lineages. Journal of Experimental Zoology, 299A (1), 13-22. https://doi.org/10.1002/jez.a.10288

Stewart, J.R. \& Thompson, M.B. (2009a) Parallel evolution of placentation in Australian scincid lizards. Journal of Experimental Zoology B Molecular and Developmental Evolution, 312 (6), 590-602. https://doi.org/10.1002/jez.b.21245

Stewart, J.R. \& Thompson, M.B. (2009b) Placental ontogeny in Tasmanian snow skinks (genus Niveoscincus) (Lacertilia: Scincidae). Journal of Morphology, 270 (4), 485-516. https://doi.org/10.1002/jmor.10704

Stewart, J.R., Ecay, T.W., Garland, C.P., Fregoso, S.P., Price, E.K., Herbert, J.F. \& Thompson, M.B. (2009) Maternal provision and embryonic uptake of calcium in an oviparous and a placentotrophic viviparous Australian lizard (Lacertilia: Scincidae). Comparative Biochemistry and Physiology, Part A: Molecular and Integrative Physiology, 153 (2), 202-208. https://doi.org/10.1016/j.cbpa.2009.02.014

Stimson, A.F., Robb, J. \& Underwood, G. (1977) Leptotyphlops and Ramphotyphlops Fitzinger, 1843 (Reptilia, Serpentes): proposed conservation under the plenary powers. Z.N.(S.)2155. Bulletin of Zoological Nomenclature, 33 (3/4), $204-207$.

Sunyer, J. (2014) An updated checklist of the amphibians and reptiles of Nicaragua. Mesoamerican Herpetology, 1 (2), 186202.

Swain, R. \& Jones, S.M. (1997) Maternal-fetal transfer of ${ }^{3} \mathrm{H}-$ labelled leucine in the viviparous lizard Niveoscincus metallicus (Scincidae: Lygosominae). Journal of Experimental Zoology, 277 (2), 139-145. https://doi.org/10.1002/(SICI)1097-010X(19970201)277:2<139::AID-JEZ5>3.0.CO;2-Q

Sy, E. (2015) Checklist of exotic species in the Philippine pet trade, II. Reptiles. Journal of Nature Studies, 14 (1), 66-93.

Tavares, M.T., Villanueva-Bonilla, G.A. \& Sobczak, J.F. (2019) Conura baturitei sp. nov. (Hymenoptera: Chalcididae): a hyperparasitoid of spiders through Zatypota riverai (Hymenoptera: Ichneumonidae). Zootaxa, 4624 (2), 267-274. https://doi.org/10.11646/zootaxa.4624.2.9

Taylor, E.R. (1935) A taxonomic study of the cosmopolitan scincoid lizards of the genus Eumeces with an account of the distribution and relationships of its species. University of Kansas Science Bulletin, 23, 1-643.

Tenorio-Mendoza, R., Martínez-Coronel, M., López-Ortega, G. \& Salgado-Ugarte, I.H. (2019) Riqueza herpetológical de la Cuenca Hidrográfica del Río Necaxa, Puebla, México. Areas Naturales Protegidas Scripta, 5 (1), 1-18.

Terán-Juárez, S.A., García-Padilla, E., Mata-Silva, V., Johnson, J.D. \& Wilson, L.D. (2016) The herpetofauna of Tamaulipas, Mexico: composition, distribution, and conservation status. Mesoamerican Herpetology, 3 (1), $43-113$.

Thompson, S.A., Pearson, S.K., While, G.M., Chapple, D.G. \& Gardner, M.G. (2020) Scat on the doorstep: refuge choice in a group-living lizard is influenced by the presence of scat piles. Austral Ecology, 45 (4), 426-434. https://doi.org/10.1111/aec.12864

Thorn, K.M., Hutchinson, M.N., Archer, M. \& Lee, M.S.Y. (2019) A new scincid lizard from the Miocene of northern Australia, and the evolutionary history of social skinks (Scincidae: Egerniinae). Journal of Vertebrate Paleontology, 39 (1), e1577873. https://doi.org/10.1080/02724634.2019.1577873

Thorn, K.M., Hutchinson, M.N., Lee, M.S.Y., Brown, N.J., Camens, A.B. \& Worthy, T.H. (2021) A new species of Proegernia from the Namba Formation in South Australia and the early evolution and environment of Australian egerniine skinks. Royal Society Open Science, 8, 201686. https://doi.org/10.1098/rsos.201686

Tinôco, R.S., Ribeiro, R.C., Tavares, M.T., Vilela, E.F., Lemos, W.de P. \& Zanuncio, J.C. (2012) Brachymeria spp. (Hymenoptera: Chalcididae) parasitizing pupae of Hersperidae and Nymphalidae (Lepidoptera) pests of oil palm in the Brazilian Amazonian region. Florida Entomologist, 95 (3), 788-789. https://doi.org/10.1653/024.095.0335

Title, P.O. \& Rabosky, D.L. (2017) Do macrophylogenies yield stable macroevolutionary inferences? An example from squamate reptiles. Systematic Biology, 66 (5), 843-856. https://doi.org/10.1093/sysbio/syw102

Townsend, J.H. (2014) Characterizing the Chortís Block Biogeographic Province: geological, physiographic, and ecological associations and herpetofaunal diversity. Mesoamerican Herpetology, 1 (2), 204-252.

Treilibs, C.E., Pavey, C.R., Gardner, M.G., Ansari, M.H. \& Bull, C.M. (2019) Spatial dynamics and burrow occupancy in a desert lizard floodplain specialist, Liopholis slateri. Journal of Arid Environments, 167, 8-17. https://doi.org/10.1016/j.jaridenv.2019.04.004

Treitschke, F. (1826) Die Schmetterlinge von Europa. Funfter Band. Dritte Ubtheilung. Gerhard Flischer, Leipzig, iv $+419+$ [1] pp.

Tschudi, J.J. de (1845) Reptilium conspectus quae in Republica Peruana reperiuntur et pleraque observata vel collecta sunt in itinere. Archiv für Naturgeschichte, 11, 150-170. 
https://doi.org/10.5962/bhl.part.7963

Ubaidillah, R. \& Kojima, J.-I. (2004) Record of Smicromorpha, (Hymenoptera: Chalcididae: Smicromorphinae) possible parasitoids of weaver ants, from Halmahera, the north Moluccas. Treubia, 33 (2), 199-201.

Uetz, P., Cherikh, S., Shea, G., Ineich, I., Campbell, P.D., Doronin, I.V., Rosado, J., Wynn, A., Tighe, K.A., Mcdiarmid, R., Lee, J.L., Köhler, G., Ellis, R., Doughty, P., Raxworthy, C.J., Scheinberg, L., Resetar, A., Sabaj, M., Schneider, G., Franzen, M., Glaw, F., Böhme, W., Schweiger, S., Gemel, R., Couper, P., Amey, A., Dondorp, E., Ofer, G., Meiri, S. \& Wallach, V. (2019) A global catalog of primary reptile type specimens. Zootaxa, 4695 (5), 438-450.

https://doi.org/10.11646/zootaxa.4695.5.2

van Blerk, D., Reissig, J., Riley, J.L., Measey, J. \& Baxter-Gilbert, J. (2021) Observations of infanticide and cannibalism in four species of cordylid lizard (Squamata: Cordylidae) in captivity and the wild. Herpetology Notes, 14, 725-729.

Vincent de Beauvais (1494) Speculum Naturale Vincentii. Hermannus, Liechtenstein, [26] + $424+$ [1] pp.

Vyas, R. \& Parasharya, B.M. (2016) Amphibian and reptilian inventories augmented by sampling at heronries. IRCF Reptiles \& Amphibians, 23 (1), 68-73.

https://doi.org/10.17161/randa.v23i1.14102

Wagler, J. (1824) Serpentum Brasiliensium species novae ou histoire naturelle des espèces nouvelles de serpens, recueillies et observées pendant le voyage dans l'intérieur du Brésil dans les années 1817, 1818, 1819, 1820, exécuté par ordre de sa Majesté le Roi de Bavière, publiée par Jean de Spix, Chevalier de l'ordre civil de la Couronne de Bavière, Membre de l'Academie Royale de Munich, Conservateur du Musée zoologique, zootomique et ethnographique, Membre de l'Académie des Curieux de la Nature etc. Franc. Seraph. Hübschmanni, Monachii, viii + 75 + [1] pp., XXVI pls.

Wagler, J.G. (1830) Natürliches System der Amphibien, mit vorangehender Classification der Säugthiere und Vögel. Ein Beitrag zur vergleichenden Zoologie. J.G. Cotta, München, vi +354 pp., 2 pls. https://doi.org/10.5962/bhl.title.108661

Watson, G.S., Green, D.W. \& Watson, J.A. (2020) Observations supporting parental care by a viviparous reptile: aggressive behaviour against predators demonstrated by Cunningham's skinks. Australian Journal of Zoology, 67 (3), 180-183. https://doi.org/10.1071/ZO20024

Watson, G.S., Green, D.W. \& Watson, J.A. (2021) Giving birth out in the open: observations of the Cunningham's skink (Egernia cunninghami) giving birth upon exposed rocks. Herpetology Notes, 14, 451-454.

Weinell, J.L., Branch, W.R., Colston, T.J., Jackman, T.R., Kuhn, A., Conradie, W. \& Bauer, A.M. (2019) A species-level phylogeny of Trachylepis (Scincidae: Mabuyinae) provides insight into their reproductive mode evolution. Molecular Phylogenetics \& Evolution, 136, 183-195. https://doi.org/10.1016/j.ympev.2019.04.002

Weinland, D.F. (1862) Beschreibung und Abbildung von drei neuern Sauriern. Abhandlungen herausgegeben von der Senckenbergischen Naturforschenden Gesellschaft, 4 (1), 131-143, pl. V.

Welch, K. (1982) Herpetology of the Old World 2. Preliminary comments on the classification of skinks (family Scincidae) with specific reference to those genera found in Africa, Europe and southwest Asia. Herptile, 7 (4), 25-27.

Welch, K.R.G. (1983) Herpetology of Europe and Southwest Asia: A Checklist and Bibliography of the Orders Amphisbaenia, Sauria and Serpentes. Robert E. Krieger, Malabar, viii + 135 pp. https://doi.org/10.2307/1444418

Welch, K.R.G., Cooke, P.S. \& Wright, A.S. (1990) Lizards of the Orient: a Checklist. Robert E. Krieger, Malabar, 162 pp.

Wermuth, H. (1969) Liste der rezenten Amphibien und Reptilien: Anguidae, Anniellidae, Xenosauridae. Das Tierreich, 90, $1-41$.

Werner, F. (1914) Ergebnisse einer von Prof. F. Werner im Sommer 1910 mit Unterstützung aus dem Legate Wedl ausgeführten zoologischen Forschungsreise nach Algerien. II. Vertebrata. Sitzungsberichte der Akademie der Wissenschaften Mathematisch-naturwissenschaftliche Klasse. Abteilung I, 123 (4), 331-362.

While, G.M., Gardner, M.G., Chapple, D.G. \& Whiting, M.J. (2019) Stable social grouping in lizards. In: Bels, V.L. \& Russell, A.P. (Eds.), Behavior of Lizards. Evolutionary and Mechanistic Perspectives. CRC Press, Boca Raton, Florida, pp. 321-339. https://doi.org/10.1201/9781498782739-11

White, J. (1790) Journal of a Voyage to new South Wales with Sixty-five Plates of Non descript Animals, Birds, Lizards, Serpents, curious Cones of Trees and other Natural Productions. J. Debrett, London, [xiii] + $299+$ [35] pp., 65 pls. https://doi.org/10.5962/bhl.title.118604

Whiting, A.S., Bauer, A.M. \& Sites, J.W. (2003) Phylogenetic relationships and limb loss in sub-Saharan African scincine lizards (Squamata: Scincidae). Molecular Phylogenetics and Evolution, 29 (3), 582-598. https://doi.org/10.1016/S1055-7903(03)00142-8

Whiting, A.S., Sites, J.W. \& Bauer, A.M. (2004) Molecular phylogenetics of Malagasy skinks (Squamata: Scincidae). African Journal of Herpetology, 53 (2), 135-146. https://doi.org/10.1080/21564574.2004.9635506

Wiegmann, A.F. (1828) Behträge zur Amphibienkunde. Isis von Oken, 21 (4), columns 364-383.

Wiegmann, A.F.A. (1834a) Herpetologia Mexicana, seu Description Amphibiorum Novae Hispaniae, quae itineribus comitis de Sack, Ferdinandi Deppe et Chr. Guil. Schiede in Museum Zoologicum Berolinense pervenerunt. Pars Prima, Saurorum Species amplectens. Adiecto Systematis Saurorum Prodromo, additisque multis in hunc Amphibiorum ordinem observatoni- 
bus. C.G. Lüderitz, Berolini, vi +54 pp., X pls.

https://doi.org/10.5962/bhl.title.119131

Wiegmann, A.F.A. (1834b) Amphibien. In: Meyen, F.J.F. Reise um die Erde ausgeführt auf dem Königlich Preussischen Seehandlungs-Schiffe Prinzess Louise, comandiert von Capitain W. Wendt, in den Jahren 1830, 1831 und 1832. Dritter Theil. Zoologischer Bericht. Sander'schen Buchhandlung, Berlin, pp. 433-522, pls. LII-LXI.

[Wiegmann, A.F.A.] (1835) Bericht uber die Fortschritte der Zoologie im Jahre 1834. Archiv für Naturgeschichte, 1 (2), 255 353.

[Wiegmann, A.F.A.] (1836) Herpetologische Notizen. Archiv für Naturgeschichte, 3 (1), 123-136. https://doi.org/10.5962/bhl.part.10047

Wiens, J.J., Hutter, C.R., Mulcahy, D.G., Noonan, B.P., Townsend, T.M., Sites, J.W. \& Reeder, T.W. (2012) Resolving the phylogeny of lizards and snakes (Squamata) with extensive sampling of genes and species. Biology Letters, 8, 1043-1046. https://doi.org/10.1098/rsbl.2012.0703

Wilson, L.D., Johnson, J.D., Porras, L.W., Mata-Silva, V. \& García-Padilla, E. (2017) A system for categorizing the distribution of the Mesoamerican herpetofauna. Mesoamerican Herpetology, 4 (4), 902-913.

Woolrich-Piña, G.A., García-Padilla, E., DeSantis, D.L., Johnson, J.D., Mata-Silva, V. \& Wilson, L.D. (2017) The herpetofauna of Puebla, Mexico: composition, distribution, and conservation status. Mesoamerican Herpetology, 4 (4), 791-844.

Worthy, T.H. (2016) A review of the fossil record of New Zealand lizards. In: Chapple, D.G. (Ed.), New Zealand Lizards. Springer, Cham, pp. 65-86.

https://doi.org/10.1007/978-3-319-41674-8_3

Worthy, T.H., de Pietri, V.L. \& Scofield, R.P. (2017) Recent advances in avian palaeobiology in New Zealand with implications for understanding New Zealand's geological, climatic and evolutionary histories. New Zealand Journal of Zoology, 44 (3), $177-211$. https://doi.org/10.1080/03014223.2017.1307235

Wüster, W., Thomson, S.A., O’Shea, M. \& Kaiser, H. (2021) Confronting taxonomic vandalism in biology: conscientious community self-organization can preserve nomenclatural stability. Biological Journal of the Linnean Society, 133 (3), $645-670$. https://doi.org/10.1093/biolinnean/blab009

Zhao, Z., Goedhals, J., Verdú-Ricoy, J., Jordaan, A. \& Heidemann, N. (2020) Comparative analysis of the eye anatomy in fossorial and surface-living skink species (Reptilia: Scincidae), with special reference to the structure of the retina. Acta Zoologica, 101 (3), 311-323. https://doi.org/10.1111/azo.12297

Zheng, Y. \& Wiens, J.J. (2016) Combining phylogenomic and supermatrix approaches, and a time-calibrated phylogeny for squamate reptiles (lizards and snakes) based on 52 genes and 4162 species. Molecular Phylogenetics and Evolution, 94 (B), 537-547.

https://doi.org/10.1016/j.ympev.2015.10.009

Zug, G.R. (2013) Reptiles and Amphibians of the Pacific Islands. A Comprehensive Guide. University of California Press, Berkeley, California, $\mathrm{x}+306 \mathrm{pp}$. https://doi.org/10.1525/9780520955400

Zweifel, R.G. (1979) Variation in the scincid lizard Lipinia noctua and notes on other Lipinia from the New Guinea region. American Museum Novitates, 2676, 1-21. 